\title{
Synthesis and biological activity of naturally occurring $\alpha$-glucosidase inhibitors
}

\author{
Duncan J. Wardrop* and Samanthi L. Waidyarachchi \\ Received 23rd March 2010 \\ DOI: 10.1039/b914958a
}

Covering: 2005 to the end of 2009

In addition to their clinical importance in the treatment of type II diabetes, $\alpha$-glucosidase inhibitors have attracted considerable attention from the synthetic community because of their profound effect on an array of cellular processes, including $N$-linked glycoprotein processing and maturation, oligosaccharide metabolism, and cell-cell and cell-virus recognition. Over the past decade, a number of structurally novel naturally occurring $\alpha$-glucosidase inhibitors which do not conform to the classical iminosugar mold have been identified, including zwitterionic thiosugars and marine organosulfates. While these natural products are important leads in the development of new classes of glucosidase inhibitors, they have also attracted considerable attention as synthetic targets in of themselves. This article reviews the recent literature concerning the synthesis of these emerging natural product families, as well as the preparation of those polyhydroxylated alkaloids more traditionally associated with anti- $\alpha$-glucosidase activity. 176 references are cited.

1 Introduction

2 Mechanism and inhibition of enzyme-mediated glycosidase hydrolysis

3 Iminosugars

3.1 Piperidines

3.2 Pyrrolidines

3.3 Pyrrolizidines

3.4 Indolizidines

4 Sulfonium-sulfate thiosugars

4.1 Salacinol

4.2 Kotalanol

4.3 De- $O$-sulfonated kotalanol

4.4 Salaprinol

4.5 Ponkoranol

4.6 Neosalacinol

5 Carbasugars

5.1 Valienamine

5.2 Valiolamine and voglibose

6 Marine organosulfates

6.1 Penoralide sulfates

6.2 Schulzeines

7 Conclusions

8 Acknowledgements

9 References

\section{Introduction}

Glycosidase enzymes catalyze the hydrolysis of glycosidic linkages by releasing monosaccharides from the non-reducing end of an oligosaccharide or glycoconjugate, and are implicated in an array of vital biological processes. ${ }^{1}$ Inhibitors of these enzymes, both natural and synthetic, have attracted considerable attention from the synthetic community because of their profound effect on $N$-linked glycoprotein processing and maturation, oligosaccharide metabolism, and cell-cell and cell-virus recognition. ${ }^{2}$ Their modulation of such biochemical processes has not only led to a deeper understanding of the role that glycosidases play in living organisms, ${ }^{3}$ but is also the basis of a number of therapeutic agents. Glycosidase inhibitors are clinically utilized as antihyperglycemic ${ }^{4}$ and anti-influenza ${ }^{5}$ agents and have potential for the treatment of viral, ${ }^{6}$ bacterial, and fungal infections, ${ }^{7}$ as well as a range of other ailments, including Gaucher's disease, ${ }^{8}$ cystic fibrosis, ${ }^{9}$ and metastatic cancer. ${ }^{10}$

Notwithstanding the remarkable progress made in this field since the mid-1970s, the ubiquitous distribution of glycosidases and the non-drug-like properties of iminosugars have ensured a continuing need to identify ever more potent and selective inhibitors as well as develop efficient synthetic routes to them. ${ }^{11}$ During the past decade, a number of structurally novel inhibitors which do not conform to the classical iminosugar mold have been identified, namely zwitterionic thiosugars and marine organosulfates. While these natural products are important leads in the development of new types of $\alpha$-glucosidase inhibitors, they have attracted considerable attention as synthetic targets in of themselves. The purpose of this article is to review the recent literature (2005 through to the end of 2009) concerning the synthesis of these emerging families of
Department of Chemistry, University of Illinois at Chicago, 845 West Taylor Street, Chicago, IL, USA. E-mail: wardropd@uic.edu; Fax: +1 312996 0431: Tel: +13123551035
Nat. Prod. Rep., 2010, 27, 1431-1468 | 1431 
inhibitors as well as advances in the preparation of alkaloid natural products more traditionally associated with $\alpha$-glucosidase inhibition. Furthermore, since such information directly impacts synthetic chemists who work in the field, our discussion will also encompass issues pertaining to structural revision.

\section{Mechanism and inhibition of enzyme-mediated glycosidase hydrolysis}

$\alpha$-Glucosidase enzymes selectively catalyse the hydrolysis of $\alpha$-glucosidic linkages and, together with $\alpha$-glycosidases in general, can be subdivided into two mechanistic classes, namely configuration-retaining and configuration-inverting, depending on the stereochemical outcome at the anomeric center of the

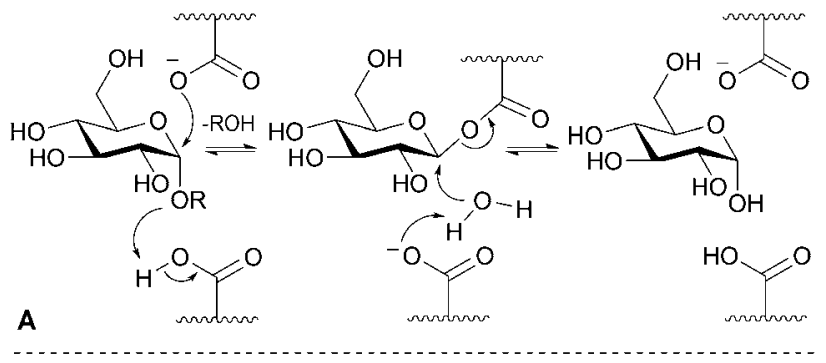

B

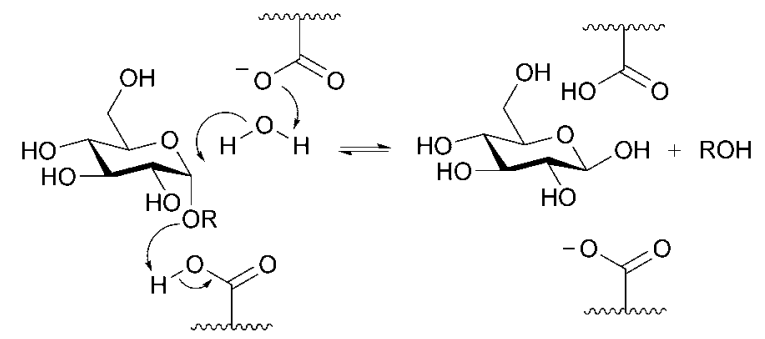

Fig. 1 Catalytic mechanisms for configuration-retaining (A) and configuration-inverting (B) $\alpha$-glycosidase enzymes according to Koshland. ${ }^{13}$ monosaccharide, which departs upon hydrolysis (Fig. 1). ${ }^{12}$ The active sites of glycosidase enzymes typically house two carboxylic acid-bearing residues (Asp or Glu) which are responsible for the mediation of hydrolysis, although the protonation state, relative location and mechanistic role of these groups differs for inverting and retaining glycosidases.

In configuration-retaining enzymes, the carboxylate residues are positioned approximately $5.5 \AA$ apart and mediate a double displacement process involving a covalent enzyme-glycosyl intermediate (Fig. 1, A). In this case, one residue adopts the role of general acid catalyst, protonating the glycosidic oxygen atom, while the other simultaneously acts as a nucleophile, attacking the anomeric center to produce the covalent intermediate. In the second step, the free carboxylate anion deprotonates an incoming water molecule, which then attacks the anomeric center to displace the enzyme carboxylate group. The carboxylate residues within the active site of configuration-inverting glycosidases are further apart (10.5 $\AA$ ), enabling simultaneous binding of the substrate and water, which undergo reaction via a single-step displacement (Fig. 1, B). In this case, one carboxylate group is deprotonated in the resting state and plays the role of general base by deprotonating the water molecule while it attacks the anomeric center. Concomitant with this process, the carboxylic acid protonates the glycosidic oxygen atom, resulting in a transition state with substantial oxacarbenium ion character (Fig. 2).

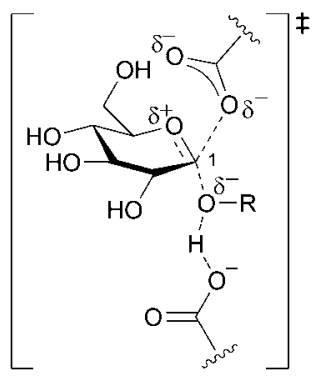

Fig. 2 Structure of the oxocarbenium ion-like transition state involved in the $\mathrm{S}_{\mathrm{N}} 2$-type hydrolysis mediated by stereoretaining $\alpha$-glucosidases.

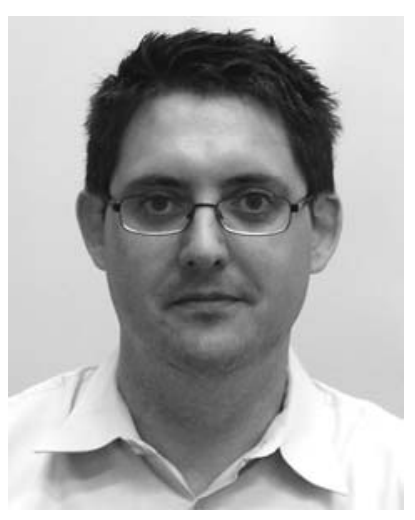

Duncan Wardrop
Duncan Wardrop obtained his B.Sc. (Hons) and Ph.D. degrees from the University of Glasgow, Scotland. After a postdoctoral appointment with James D. White at Oregon State University, he joined the faculty at the University of Illinois at Chicago, where he is now Associate Professor of Chemistry. His research interests encompass the chemistry of alkylidenecarbenes and nitrenium ions, and the application of these electrondeficient, divalent species to the synthesis of natural products.

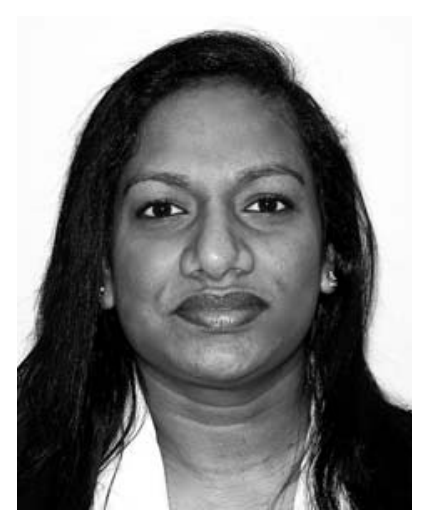

Samanthi Waidyarachchi
Samanthi Waidyarachchi obtained her B.Sc. (Hons) degree in Chemistry from the University of Kelaniya, Sri Lanka, where she worked as an undergraduate, with a focus on biochemistry. She is currently a graduate student in the research group of Duncan Wardrop, at the University of Illinois at Chicago, where her research focus is on the development of the nitrenium ion-mediated cyclofunctionalization reaction and the application of this transformation to the synthesis of pyrrolizidine alkaloids. 

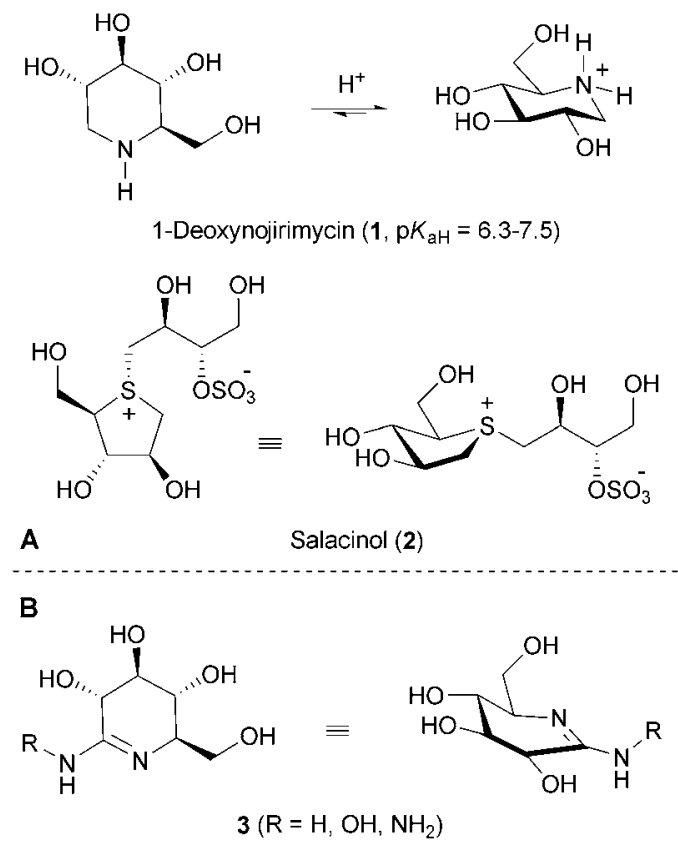

Fig. 3 Electrostatic and structural mimicry of the oxocarbenium-like transition state are among the factors believed to be responsible for the biological activity of iminosugar $\alpha$-glucosidases inhibitors and their surrogates. A. Mimicry of the positive charge at the endocyclic oxygen atom. B. Mimicry of the half-chair structure adopted in the transition state associated with stereoretaining $\alpha$-glucosidases.

Since the positive charge at the anomeric center in the transition state shown in Fig. 2 is substantially shared with endocyclic oxygen, the $\mathrm{C} 1-\mathrm{O}$ bond has significant double bond character. As a consequence, the ground-state chair conformation of the glycosyl ring is distorted into a boat or half-chair as the transition state is approached. Although the designation of glycosidase inhibitors as transition state mimics remains a topic of much debate, ${ }^{14}$ electrostatic (Fig. 3A) and structural (Fig. 3B) mimicry of these transient species have proven to be particularly effective strategies in the design of such inhibitors.

In the case of iminosugars (2-aza sugars), such as 1-dexoxynojirimycin (1), the presence of an endocyclic nitrogen protonated under physiological conditions is believed to emulate the positive charge on the ring oxygen at the transition state, but not the flattened conformation. ${ }^{15,16}$ Similar arguments have also been posited in the case of the zwitterionic $\alpha$-glucosidase inhibitor salicinol (2), in which a sulfonium center appears to behave as a surrogate for the developing positive on the endocyclic oxygen (see Section 4). ${ }^{120}$ Isoiminosugars (1-aza sugars) are also believed to derive their inhibitory activity through electrostatic mimicry, although in these systems, the protonated nitrogen plays the role of the positively charged anomeric center. ${ }^{17}$ With regard to structural mimicry, inhibitors such as nojirimycin derivatives $3,{ }^{18}$ which adopt a distorted half-chair conformation, are believed to derive a significant portion of their binding properties from structural mimicry of the glycosidase transition state. While electrostatic charge is clearly a further factor in the activity of amidine derivative $3(X=H)$, which is protonated under physiological conditions, Ganem, in light of the activity of the nonbasic amidoxime $3(\mathrm{X}=\mathrm{OH})$, has suggested that adoption of

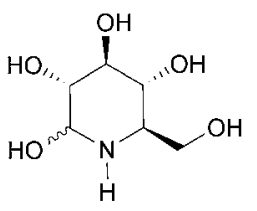

Nojirimycin (4)

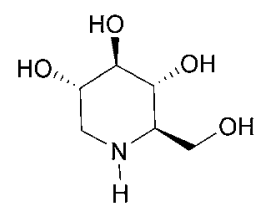

1-Deoxynojirimycin (1)
Fig. 4 Structure of the inaugural iminosugar glycosidase inhibitors nojirimycin $(4, \mathrm{NJ})$ and 1-deoxynojirimycin $(\mathbf{1}, \mathrm{DNJ})$.

the flattened anomeric conformation of the glucosyl intermediate may be more important for transition state binding than achieving the full charge of the glucopyranosyl cation.

\section{Iminosugars}

Since the discovery of nojirimycin (4) in 1967 (Fig. 4), ${ }^{19}$ iminosugar-based glycosidase inhibitors have been the subject of intense scrutiny, ${ }^{20}$ not only for their profound effect on glycosidases but for their inhibition of other carbohydrate-processing enzymes, including glycosyltransferases, ${ }^{21}$ glycogen phosphorylases, ${ }^{22}$ and nucleoside phosphorylases. ${ }^{23}$ The role played by $\alpha$-glucosidase inhibitors in the development of this field has been particularly important in light of their clinically proven value in the treatment of type II diabetes ${ }^{4}$ and hereditary lysosomal storage diseases. ${ }^{8}$

Notwithstanding a remarkable degree of constitutional diversity, iminosugars can generally be categorized as belonging into one of five major structural groups, namely piperidines (5), pyrrolidines (6), pyrrolizidines (7), indolizidines (8) and nortropanes (9) (Fig. 5). While a majority of the several hundred known iminosugar inhibitors are synthetic in origin, in almost all cases the basis for their design is, to some degree, structurally attributable to alkaloidal natural products. $^{20}$

\subsection{Piperidines}

Polyhydroxylated piperidines constitute the largest subgroup of $\alpha$-glucosidase inhibitors among which (+)-1-deoxynojirimycin (DNJ, 1) and its analogues have been the most intensively studied (Fig. 4). Isolated from both plant and microbial sources, ${ }^{24}$ DNJ displays inhibitory activity against a variety of $\alpha$ - and $\beta$ glycosidase enzymes in a reversible or competitive manner. ${ }^{25}$ Notably, the synthesis of this compound, first reported by Paulsen in $1966,{ }^{26}$ actually predates its isolation from natural sources by at least a decade. Given the central importance of deoxynojirimycin

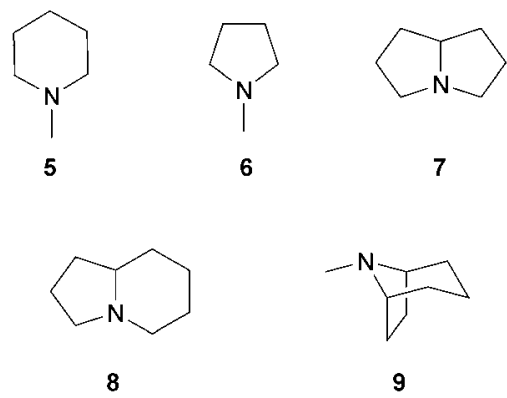

Fig. 5 Skeletal frameworks most commonly found in naturally occurring iminosugar glycosidase inhibitors and their synthetic derivatives. 

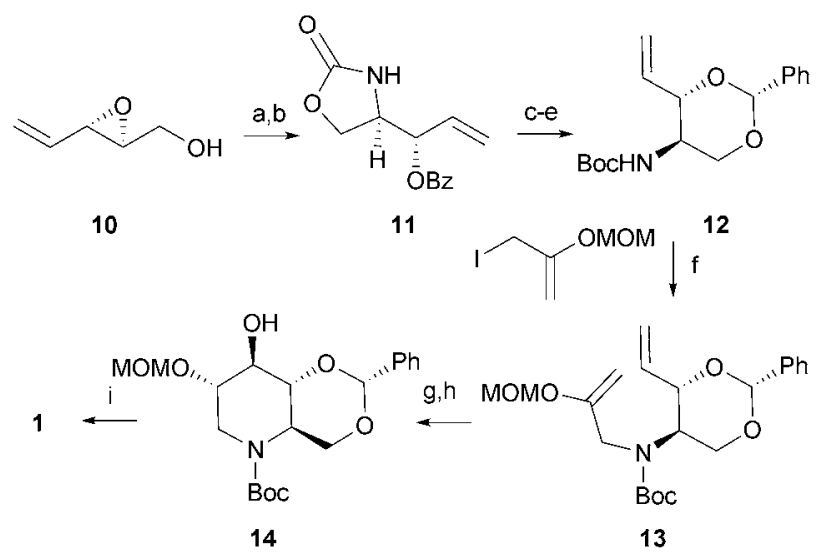

Scheme 1 Poisson's synthesis of (+)-1-deoxynojirimycin [(+)-DNJ]. Reagents and conditions: (a) $\mathrm{BzNCO}, \mathrm{Et}_{2} \mathrm{O}, 0{ }^{\circ} \mathrm{C}$; (b) $\mathrm{K}_{2} \mathrm{CO}_{3}$, $\mathrm{C}_{12} \mathrm{H}_{25} \mathrm{NMeCl}, 20^{\circ} \mathrm{C}, 6 \mathrm{~h}, 77 \%$; (c) $\mathrm{Boc}_{2} \mathrm{O}, \mathrm{Et}_{3} \mathrm{~N}$, DMAP, $\mathrm{CH}_{2} \mathrm{Cl}_{2}, \mathrm{rt}, 90$ min; (d) NaOEt, EtOH, $0 \rightarrow 20{ }^{\circ} \mathrm{C}, 1 \mathrm{~h}$; (e) $\mathrm{PhCH}(\mathrm{OMe})_{2}$, CSA, $20{ }^{\circ} \mathrm{C}$, $6 \mathrm{~h}, 77 \%$ (3 steps); (f) NaH, DMF, $0{ }^{\circ} \mathrm{C}, 2$ h, $82 \%$; (g) Hoveyda-Grubbs II catalyst, benzoquinone, $\mathrm{PhCH}_{3}$, heat, $87 \%$; (h) $\mathrm{BH}_{3} \cdot \mathrm{SMe}_{2}, \mathrm{THF}$, $\mathrm{NaBO}_{3}, \mathrm{H}_{2} \mathrm{O}, 0 \rightarrow 20{ }^{\circ} \mathrm{C}, 70 \%$; (i) $\mathrm{HCl}$, EtOH, reflux, $18 \mathrm{~h}, 100 \%$.

as a template in the development of glycosidase inhibitors, it is not suprising that more than forty years after its isolation, this simple yet important molecule remains a popular synthetic target. To date, more than 30 total syntheses of 1-deoxynojirimycin have been reported. ${ }^{27}$

Recently, Poisson and co-workers have reported the development of a highly stereocontrolled synthesis of (+)-1-deoxynojirimycin (1), which features the use of a novel one-pot enol ether metathesis-hydroboration sequence to establish the all-trans cyclic triol (Scheme 1). ${ }^{28}$ The high diastereoselectivity of the hydroboration step in this case is notable in light of Takahata's earlier observation that dihydroxylation of related metathesis products proceeded with moderate selectivity. ${ }^{29}$ In Poisson's route, treatment of $(2 S, 3 S)$-epoxyalcohol $\mathbf{1 0}$ with benzoyl isocyanate generated the corresponding benzoylcarbamate which, upon exposure to base under biphasic conditions, underwent regioselective epoxide opening and intramolecular benzoyl migration to yield oxazolidinone $11 .{ }^{30}$ After conversion of this material to diene 13, ring-closing metathesis (RCM) using the Hoveyda-Grubbs II catalyst generated the corresponding piperidine. Hydroborationoxidation of this cyclic enol ether then furnished trans diol derivative $\mathbf{1 4}$ as a single diastereomer $(\mathrm{dr}>95: 5)$ in good overall yield. Finally, treatment with ethanolic $\mathrm{HCl}$ afforded (+)-1-deoxynojirimycin (1) in 11 linear steps and with an overall yield of $24 \%$.

Jung and co-workers have also gainfully employed RCM to access the piperidine ring of DNJ (1) and two of its stereoisomers (Scheme 2). ${ }^{31}$ Commencing from $p$-anisaldehyde (15), Roush anti- $\alpha$-silylallylation employing Brown's diisopinocampheyl auxiliary, ${ }^{32}$ Tamao-Fleming oxidation and subsequent di- $O$ benzylation provided anti-1,2-dibenzyl ether $\mathbf{1 6}$ with excellent stereocontrol. Diastereoselective and regioselective benzylic amination of $\mathbf{1 6}$ was now accomplished by treatment with chlorosulfonyl isocyanate, which following in situ de- $N$-sulfonylation, afforded 17 in high yield. $N$-Allylation and RCM using Grubbs' 1st-generation catalyst provided alkene 18, which upon dihydroxylation using the Upjohn procedure, was converted to<smiles>C=CC(OCc1ccccc1)[C@H](NC(=O)[C@H](C=C)OCc1ccccc1)c1ccc(OC)cc1</smiles>

18 f<smiles>COc1ccc([C@H]2[C@H](OCc3ccccc3)[C@@H](O)[C@@H](O)CN2C(=O)OCc2ccccc2)cc1</smiles>

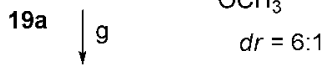

$19 \mathrm{~b}$

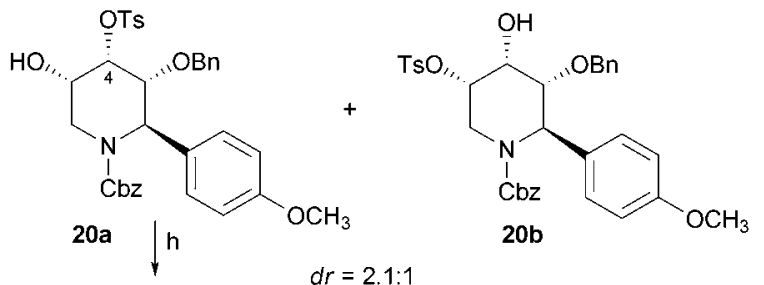

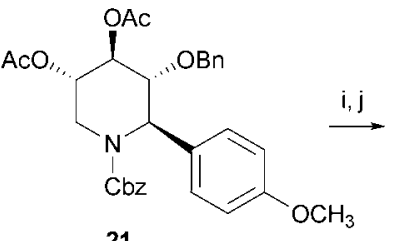

21

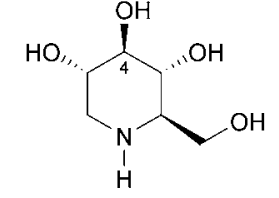

$(+)-1-$ Deoxynojirimycin (1)
Scheme 2 Jung's synthesis of (+)-DNJ. Reagents and conditions: (a) allyl (diisopropylamino)dimethylsilane, $n$-BuLi, TMEDA, $\beta$-methoxy$\mathrm{B}(\mathrm{Ipc})_{2} \cdot \mathrm{BF}_{3} \cdot \mathrm{OEt}_{2}, \mathrm{Et}_{2} \mathrm{O},-78{ }^{\circ} \mathrm{C}, 3 \mathrm{~h}$; then $\mathrm{KF}, \mathrm{KHCO}_{3}, 30 \% \mathrm{H}_{2} \mathrm{O}_{2}$, THF, MeOH, rt, 20 h, 52\%; (b) NaH, BnBr, THF, DMF, rt, 11 h, 99\%, (c) chlorosulfonyl isocyanide, $\mathrm{Na}_{2} \mathrm{CO}_{3}, \mathrm{PhCH}_{3},-78{ }^{\circ} \mathrm{C}, 24 \mathrm{~h}$; then $\mathrm{Na}_{2} \mathrm{SO}_{3}, \mathrm{rt}, 24 \mathrm{~h}, 90 \%, \mathrm{dr}=50: 1$; (d) $\mathrm{NaH}$, allyl bromide, THF, DMF, rt, 2 h, 100\%; (e) Grubbs' 1st-generation catalyst, $\mathrm{CH}_{2} \mathrm{Cl}_{2}, \mathrm{rt}, 4 \mathrm{~h}, 91 \%$; (f) cat. $\mathrm{OsO}_{4}, \mathrm{NMO}, \mathrm{Ac}_{2} \mathrm{O}-\mathrm{H}_{2} \mathrm{O}(4: 1), 75 \%, \mathrm{dr}=6: 1$; (g) TsCl, $\mathrm{Et}_{3} \mathrm{~N}$, DMAP, $\mathrm{CH}_{2} \mathrm{Cl}_{2}, \mathrm{rt}, 2 \mathrm{~h}, 99 \%, \mathrm{dr}=2.1: 1$; (h) $\mathrm{Ac}_{2} \mathrm{O}$, DMAP, $\mathrm{Et}_{3} \mathrm{~N}$, $\mathrm{CH}_{2} \mathrm{Cl}_{2}$, rt, 2 h, 99\%; (i) CsOAc, DMF, $60{ }^{\circ} \mathrm{C}, 4$ h, 74\%; (j) cat. $\mathrm{RuCl}_{3}$, $\mathrm{NaIO}_{4}, \mathrm{H}_{2} \mathrm{O}-\mathrm{MeCN}-\mathrm{EtOAc}(2: 1: 1)$, rt, 4 h; (k) $\mathrm{BH}_{3} \cdot \mathrm{THF}, \mathrm{THF}, 0^{\circ} \mathrm{C}$, $24 \mathrm{~h}, 52 \%$ (2 steps); (1) $6 \mathrm{M} \mathrm{HCl}, \mathrm{MeOH}$, reflux, $12 \mathrm{~h}$; (m) Dowex-50WX8 ( $\mathrm{H}^{+}$form, $0.5 \mathrm{M} \mathrm{NH}_{4} \mathrm{OH}$ ), 94\% (2 steps).

a separable mixture of cis-diols 19. Monotosylation of 19a now proceeded with modest selectivity at the equatorially-positioned C4 hydroxyl group to provide a mixture of compounds 20a and 20b. After acetylation of the remaining hydroxyl group in 20a, stereoinversion at $\mathrm{C} 4$ was accomplished by treatment with caesium acetate in DMF. Sharpless oxidative degradation of the $p$-methoxyphenyl substitutent in 21, reduction of the resulting carboxylic acid and sequential ester hydrolysis then provided DNJ (1).

In contrast to the work of both Poisson and Jung, Hirai's synthesis of DNJ (1) employs the palladium(II)-catalyzed cyclization of an allylic alcohol to construct the piperidine ring 
<smiles>CCCOC(C1COC(C)(C)O1)[C@@H](C=CC(=O)OCC)OCC</smiles><smiles>C[14C](=O)OC/C=C/[C@@H](Cc1ccccc1)[C@@H](O)[C@H](O)CO</smiles>
$\downarrow k$, I

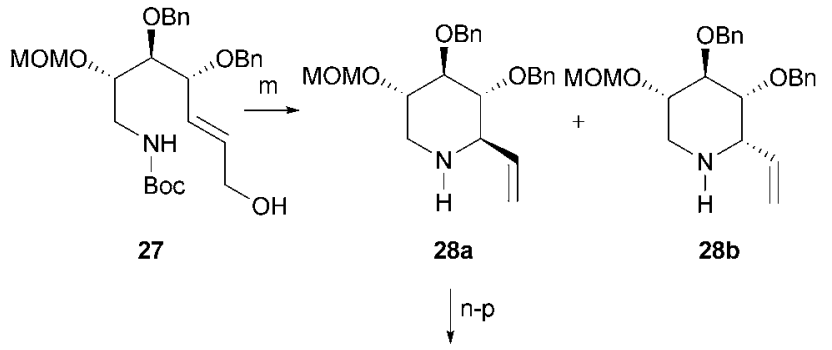

(+)-1-Deoxynojirimycin (1)

Scheme 3 Hirai's synthesis of (+)-DNJ. Reagents and conditions: (a) $\mathrm{NaIO}_{4}, \mathrm{Et}_{2} \mathrm{O}-\mathrm{H}_{2} \mathrm{O}, 0{ }^{\circ} \mathrm{C}, 79 \%$; (b) $\left(\mathrm{Et}_{2} \mathrm{O}\right) \mathrm{P}(\mathrm{O}) \mathrm{CH}_{2} \mathrm{CO}_{2} \mathrm{Et}$, NaH, THF, $0{ }^{\circ} \mathrm{C}, 89 \%$; (c) DIBAL-H, THF, $-78{ }^{\circ} \mathrm{C}, 94 \%$; (d) PivCl, pyridine, THF, $0{ }^{\circ} \mathrm{C}, 93 \%$; (e) $\mathrm{HCl}-\mathrm{H}_{2} \mathrm{O}$ (1:9), THF, $40{ }^{\circ} \mathrm{C}, 95 \%$; (f) $\mathrm{BzCl}$, pyridine, $\mathrm{CH}_{2} \mathrm{Cl}_{2}, \mathrm{rt}, 78 \%$; (g) TsCl, pyridine, $\mathrm{CH}_{2} \mathrm{Cl}_{2}, \mathrm{rt}, 85^{\circ} \mathrm{C}$; (h) $\mathrm{K}_{2} \mathrm{CO}_{3}, \mathrm{MeOH}$, rt, $68 \%$; (i) $\mathrm{NaN}_{3}, \mathrm{NH}_{4} \mathrm{Cl}, 15$-crown-5, DMF, $55^{\circ} \mathrm{C}, 76 \%$; (j) $\mathrm{MOMCl}, i$ $\mathrm{Pr}_{2} \mathrm{NEt}$, rt, 99\%; (k) $\mathrm{LiAlH}_{4}, \mathrm{Et}_{2} \mathrm{O}, 0{ }^{\circ} \mathrm{C}$; (l) (Boc) $)_{2} \mathrm{O}, \mathrm{Na}_{2} \mathrm{CO}_{3}, \mathrm{CH}_{2} \mathrm{Cl}_{2}$, rt $75 \%$ (2 steps); (m) $\mathrm{PdCl}_{2}\left(\mathrm{MeCN}_{2}\right.$ (10 mol\%), THF, rt, 76\%; (n) $\mathrm{O}_{3}$, $\mathrm{CH}_{2} \mathrm{Cl}_{2}-\mathrm{MeOH},-78{ }^{\circ} \mathrm{C}$; then $\mathrm{NaBH}_{4},-78{ }^{\circ} \mathrm{C}, \mathrm{rt}, 94 \%$; (o) $\mathrm{HCl}-\mathrm{H}_{2} \mathrm{O}$ (1 : 9), $\mathrm{MeOH}, 70{ }^{\circ} \mathrm{C}, 90 \%$; (p) $\mathrm{H}_{2}$, Pd/C, $12 \mathrm{M} \mathrm{HCl}-\mathrm{EtOH}, \mathrm{rt}, 92 \%$.

(Scheme 3). ${ }^{33}$ Starting from 22, this D-mannitol derivative was converted to unsaturated ester $\mathbf{2 3}$ through oxidative cleavage of the 1,2-diol and a Horner-Wadsworth-Emmons reaction. Reduction of the ester, pivolylation of the resulting allylic alcohol, and hydrolysis of the acetonide group provided diol 24 in high overall yield. After selective benzoylation of the primary alcohol, the secondary alcohol was transformed to a tosylate ester, which upon exposure to $\mathrm{K}_{2} \mathrm{CO}_{3}$ in methanol, afforded 25. Ring opening of this epoxide with sodium azide in DMF generated a $\beta$-hydroxy azide which was $O$-alkylated with $\mathrm{MOMCl}$ to yield compound 26. Reduction of the azide group with $\mathrm{LiAlH}_{4}$ and $\mathrm{N}$-(tert-butyloxy)carbonylation of the amine afforded key intermediate 27. Treatment of 27 with catalytic $\mathrm{PdCl}_{2}(\mathrm{MeCN})_{2}$ now mediated cyclization to furnish the allequatorially-substituted piperidine $\mathbf{2 8}$ in good yield, albeit with modest diastereoselectivity $(\mathrm{dr}=2: 1)$. After separation, ozonolysis of the vinyl group of $\mathbf{2 8 a}$, reductive workup and subsequent removal of the $\mathrm{Cbz}, \mathrm{MOM}$ and $O$-benzyl protecting groups provided DNJ (1).

Mandal and co-workers have reported an 11-step synthesis of (+)-DNJ pentaacetate (33) which centers on generation of piperidine ring through the reductive amination of latent aldehyde 31 (Scheme 4). ${ }^{34}$ This key intermediate was prepared from

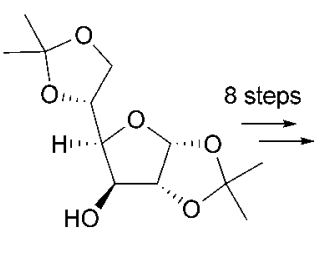

29

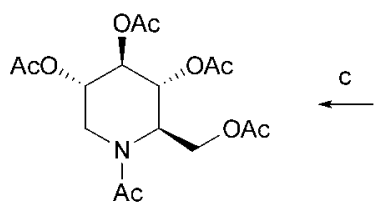

(+)-DNJ pentaacetate $(33)$

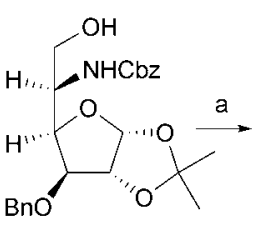

30

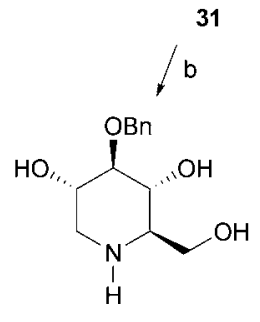

32

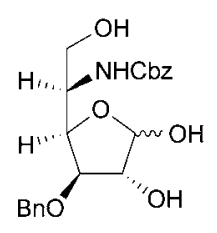

31
Scheme 4 Mandal's synthesis of (+)-DNJ pentaacetate. Reagents and conditions: (a) TFA- $\mathrm{H}_{2} \mathrm{O}(3: 2), \mathrm{rt}, 5 \mathrm{~h}, 89 \%$; (b) $\mathrm{H}_{2}, \mathrm{Pd} / \mathrm{C}\left(10 \mathrm{~mol}^{\%}\right)$, $\mathrm{MeOH}, 24 \mathrm{~h}, 45 \%$; (c) $\mathrm{H}_{2}, \mathrm{Pd}(\mathrm{OH})_{2} / \mathrm{C}, \mathrm{MeOH}, 6 \mathrm{~h}$; then $\mathrm{Ac}_{2} \mathrm{O}$, pyridine, rt, $12 \mathrm{~h}, 70 \%$ (2 steps).

$\alpha$-D-glucofuranose 29 by way of 30 . After removal of the acetonide group in 30, catalytic hydrogenation over $\mathrm{Pd} / \mathrm{C}$ in $\mathrm{MeOH}$ resulted in removal of the $\mathrm{Cbz}$ group and concomitant intramolecular reductive amination. Hydrogenolysis of the remaining benzyl ether in $\mathbf{3 2}$ was accomplished using Pearlman's catalyst and provided (+)-DNJ pentaacetate (33).

While 1-deoxynojirimycin (1) exhibits potent anti-glycosidase activity in vitro, its low in vivo efficacy, which stems in part from its pronounced hydrophilicity, has stimulated much interest in the preparation of more "drug-like" derivatives with improved pharmacokinetic properties. In particular, alkylation of the ring nitrogen has been found to both enhance the uptake of this iminosugar into mammalian cells and modify its specificity of inhibition in vitro. It is notable, in this context, that the iminosugarbased drugs which have to date reached the clinical marketplace are both $N$-alkylated derivatives of DNJ: $N$-(2-hydroxyethyl)-DNJ (Miglitol ${ }^{\circledR} /$ Glyset $^{\circledR}$ ) is approved for the control of diabetes mellitus type 2, while $N$-butyl-DNJ (Zavesca ${ }^{\circledR}$ ) is indicated for Gaucher's disease, a glycolipid lysosomal storage disorder., ${ }^{4,8}$

Fleet's pioneering studies of $N$-alkylated DNJ derivatives ${ }^{35}$ has revealed that increases in $N$-alkyl chain length have a profound effect on endoplasmic reticulum (ER) $\alpha$-glucosidase I inhibition. ${ }^{36}$ It has been suggested that this effect is related to the hydrophobicity of the alkyl chain and its localization within the ER membrane. Studies by Asano also indicate that the conformation of the $N$-alkyl chain plays a role in the activity of these inhibitors. ${ }^{37}$ In order to further understand the factors that govern iminosugar entry to the ER and potential binding partners, Fleet and co-workers have recently prepared the photolabile DNJ derivatives $\mathbf{3 5 b}$ and $\mathbf{3 6}$ shown in Scheme 5 and employed these compounds in an affinity labelling study. ${ }^{38}$

Reductive alkylation of DNJ (1) with aldehydes 34a-c, in the presence of $\mathrm{NaBH}_{3} \mathrm{CN}$ and acetic acid in methanol provided the target compounds in good to excellent yield (Scheme 5). Biological testing of these products against ER $\alpha$-glucosidases I and II revealed that compounds 35a $(n=5), \mathbf{3 5 b}$, and $\mathbf{3 6}$ have increased potency over $N$-butyl-DNJ. Most notably, aryl azide 35b not only proved to be a highly potent inhibitor of $\alpha$-glucosidase I ( $\mathrm{IC}_{50}, 17$ 


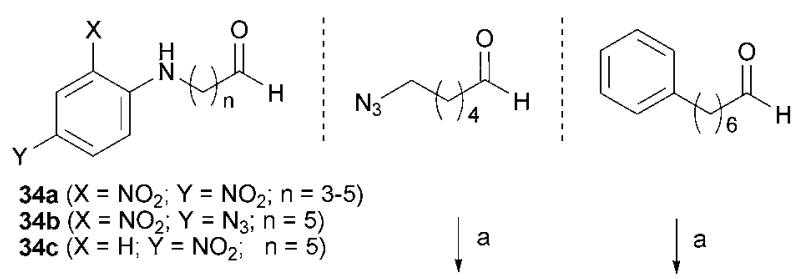
34b $\left(X=\mathrm{NO}_{2} ; \mathrm{Y}=\mathrm{N}_{3} ; n=5\right)$
$34 \mathrm{c}\left(\mathrm{X}=\mathrm{H} ; \mathrm{Y}=\mathrm{NO}_{2} ; n=5\right)$
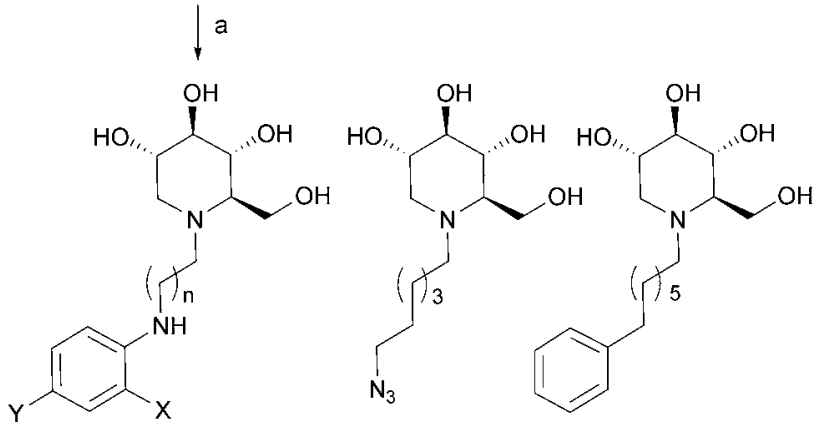

35a $\left(X=\mathrm{NO}_{2} ; Y=\mathrm{NO}_{2} ; n=3-5\right)$

$35 \mathrm{~b}\left(\mathrm{X}=\mathrm{NO}_{2} ; \mathrm{Y}=\mathrm{N}_{3} ; \mathrm{n}=5\right)$

$35 \mathrm{c}\left(\mathrm{X}=\mathrm{H} ; \mathrm{Y}=\mathrm{NO}_{2} ; \mathrm{n}=5\right)$

Scheme 5 Fleet's synthesis of photosensitive $N$-alkyl-DNJ derivatives. Reagents and conditions: (a) DNJ (1), $\mathrm{NaCNBH}_{3}, \mathrm{AcOH}, \mathrm{MeOH}$, rt.<smiles>[R]N1C[C@H](O)[C@@H](O)[C@H](O)[C@@H]1CO</smiles>

$$
\begin{aligned}
& \text { 38a }\left(\mathrm{R}=\left(\mathrm{CH}_{2}\right)_{n} \mathrm{CH}_{3} ; n=3-5\right) \\
& \text { 38b }\left(\mathrm{R}=\left(\mathrm{CH}_{2}\right)_{n} \mathrm{Ph} ; n=1,4-6\right) \\
& \text { 38c }\left(\mathrm{R}=\left(\mathrm{CH}_{2}\right)_{n} \mathrm{Cy}-\mathrm{Hex} ; n=2,4\right) \\
& \text { 38d }\left(\mathrm{R}=\left(\mathrm{CH}_{2}\right)_{n} \text { OCy-Hex; } n=5\right) \\
& \text { 38e }\left(\mathrm{R}=\left(\mathrm{CH}_{2}\right)_{n} \mathrm{Cy}-\mathrm{Pen} ; n=5\right)
\end{aligned}
$$

Fig. 6 Butters' $N$-alkyl and $N$-arylalkyl analogues of the naturally occurring glycosidase inhibitor 1-deoxynojirimycin.

$\mathrm{nM}$ ), but also inhibited cellular ER $\alpha$-glucosidases with equal potency.

Butters has recently extended the study of $N$-alkylated DNJ derivatives through the preparation of a library of substrates in which an alkyl chain of 1 to 6 carbons provides a flexible linker between DNJ and phenyl, cyclohexyl or cyclopentyl groups (Fig. 6). ${ }^{39}$ Utilizing the reductive amination coupling strategy previously outlined, compounds 38a-e were prepared from DNJ and the requisite aldehydes. Employing a free oligosaccharide (FOS) assay, these iminosugars were evaluated for their activity against ER $\alpha$-glucosidase I in cells. These studies revealed that maximal glycosidase inhibitory activity was observed where the linker was comprised of 4-6 carbon atoms and a phenyl group.

Murphy and Zhou have reported the use of an intramolecular Huisgen 1,3-dipolar cycloaddition reaction to simultaneously generate the piperidine ring and establish the C5 center of DNJ (Scheme 6). ${ }^{40}$ Upon heating, unsaturated azide 40, which was obtained in 6 steps from D-glucono- $\delta$-lactone (39), ${ }^{41}$ underwent $[2+3]$ cycloaddition to yield acid-sensitive triazoline 41 with excellent stereocontrol, albeit in moderate yield. Treatment of $\mathbf{4 1}$ with silica gel led to extrusion of dinitrogen and the formation of bicyclic aziridine $\mathbf{4 2}$, which was of sufficient stability to be isolated but not fully characterised. Hydrogenation of $\mathbf{4 2}$ over $\mathrm{Pd} / \mathrm{C}$ led to ring opening and the formation of an inseparable mixture of DNJ derivatives $\mathbf{4 4}$ and $\mathbf{4 3}$. Notably, Murphy has found that

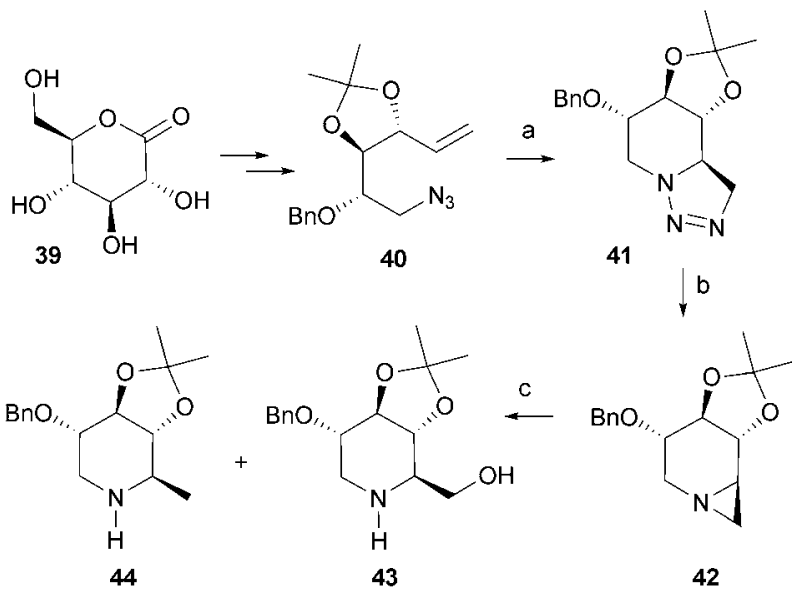

Scheme 6 Murphy and Zhou's route to (+)-DNJ derivatives. Reagents and conditions: (a) DMF or $\mathrm{PhCH}_{3}, 110{ }^{\circ} \mathrm{C}, 55 \%$; (b) silica gel, $\mathrm{PhCH}_{3}$, $20{ }^{\circ} \mathrm{C}, 35 \%$; (c) $10 \% \mathrm{Pd} / \mathrm{C}$, EtOAc, $20{ }^{\circ} \mathrm{C}, 78 \%, \mathbf{4 4 : 4 2}=1: 1.5$.

42 can be intercepted with a range of nucleophiles, including acetate, azide and thiophenol, thus offering convenient, one-pot access to a range of usefully functionalized DNJ derivatives.

Employing the diastereoselective aldol additions of metalated bislactim ethers to matched and mismatched erythrose or threose

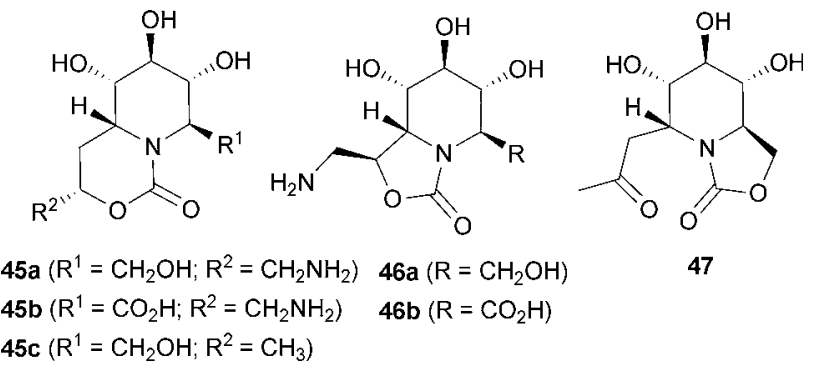

Fig. 7 Structure of Cipolla's nojirimycin (NJ)-based $\alpha$-glucosidase inhibitors.

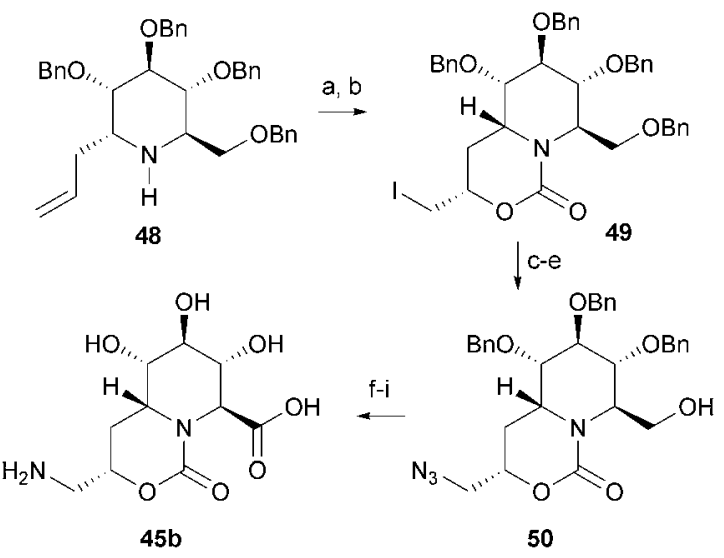

Scheme 7 Cipolla's route to conformationally restricted bicyclic nojirimycin derivatives. Reagents and conditions: (a) $\mathrm{CbzCl}$, DIPEA, $\mathrm{MeCN}$, $58 \%$; (b) $\mathrm{I}_{2}, \mathrm{CH}_{2} \mathrm{Cl}_{2}, 0{ }^{\circ} \mathrm{C}, 92 \%$; (c) $\mathrm{NaN}_{3}, n-\mathrm{Bu}_{4} \mathrm{NI}, \mathrm{CH}_{2} \mathrm{Cl}_{2}, 88 \%$; (d) $\mathrm{Ac}_{2} \mathrm{O}$, TFA, 72\%; (e) $\mathrm{MeOH}$, cat. Na, 95\%; (f) IBX, DMSO; (g) $\mathrm{NaPO}_{4} \mathrm{H}_{2} \cdot 2 \mathrm{H}_{2} \mathrm{O}, \mathrm{NaClO}_{2}, \mathrm{CH}_{3} \mathrm{CN}, 72 \%$ (2 steps); (h) $\mathrm{H}_{2}, \mathrm{Pd}(\mathrm{OH})_{2} / \mathrm{C}$, $\mathrm{AcOH}$, acetone- $\mathrm{H}_{2} \mathrm{O}, 100 \%$. 
acetonides, Ruiz and Ojea have developed a general strategy for the preparation of 1,5-iminohexitols related to 1-deoxynojirimycin. ${ }^{42}$

In an effort to access nojirimycin analogues with a flattenedchair conformation resembling the glycosidase transition state, Cipolla and co-workers have prepared a small library of conformationally restricted bicyclic nojirimycin (NJ) derivatives, which incorporate functional groups capable of being protonated under physiological conditions, including amines, ureas, cyclic carbamates and guanidines (Fig. 7) ${ }^{43}$

Employing $\alpha$ - $C$-allyl nojirimycin derivative 48, introduction of a confomationally rigidifying 1,3-oxazinan-2-one ring was accomplished through halofunctionalization of the corresponding $\mathrm{Cbz}$ derivative (Scheme 7). Iodocyclization in this case was readily effected by treatment with $\mathrm{I}_{2}$, which furnished iodide 49 as a single diastereomer in excellent yield. Functionalization of the oxazinanone ring was now accomplished through a sequence of nucleophilic substitution and regioselective de- $O$-benzylation to yield primary alcohol 50. Sequential oxidation and hydrogenolysis then afforded bicyclic NJ derivative 45b. Employing the same strategy, $\alpha$ - $C$-vinyl nojirimycin derivative $\mathbf{5 1}$ was converted to $\mathbf{4 6} \mathbf{b}$, the oxazolidinone analogue of compound $\mathbf{4 5 b}$ (Scheme 8). Through minor modification of the strategies outlined in Schemes 7 and 8, a range of other bicyclic NJ anlogs were also accessed. While these novel nojirimycin-derived bicycles failed to display appreciable antibacterial activity, a number of the cyclic carbamate derivatives did prove to be inhibitors of $\alpha$-glucosidase in the $\mu \mathrm{M}$ range.

In 2000, Asano and co-workers reported the isolation of a novel family of $\alpha$-1-C-alkylated analogues of 1-deoxy-homonojirimycin and fagomine (1,2-dideoxynojirimycin) from Adenophora triphylla ${ }^{44}$ and Lobelia sessilifolia. (Fig. 8). ${ }^{45}$ From among this series of alkyliminosugars, 1-O- $\beta$-D-glucopyranosyl-5-deoxyadenophorine (55) and $\alpha$-1-deoxy-1- $C$-methylhomonojirimycin (adenophorine, 56) were found to be $\alpha$-glucosidase inhibitors. That the presence of an $\alpha-1-C$-alkyl substituent in deoxyiminosugars is not necessarily detrimental to the biological activity
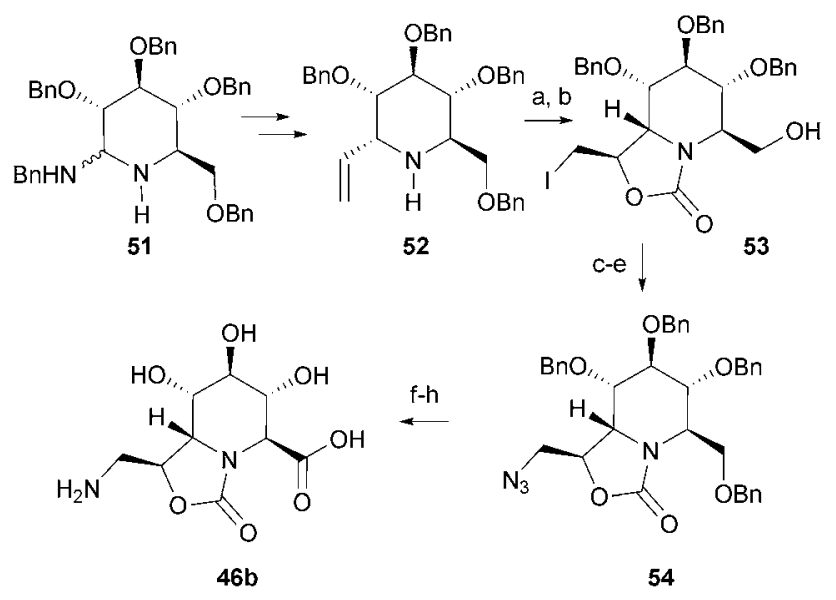

Scheme 8 Cipolla's route to conformationally restricted bicyclic nojirimycin derivatives. Reagents and conditions: (a) $\mathrm{CbzCl}$, DIPEA, $\mathrm{MeCN}$, $58 \%$; (b) $\mathrm{I}_{2}, \mathrm{CH}_{2} \mathrm{Cl}_{2}, 0{ }^{\circ} \mathrm{C}, 84 \%$; (c) $\mathrm{NaN}_{3}, n$ - $\mathrm{Bu}_{4} \mathrm{NI}, \mathrm{CH}_{2} \mathrm{Cl}_{2}, 97 \%$; (d) $\mathrm{Ac}_{2} \mathrm{O}$, TFA, 74\%; (e) $\mathrm{MeOH}$, cat. Na, 78\%; (f) IBX, DMSO; (g) $\mathrm{NaPO}_{4} \mathrm{H}_{2} \cdot 2 \mathrm{H}_{2} \mathrm{O}_{2}, \mathrm{NaClO}_{2}, \mathrm{CH}_{3} \mathrm{CN}, 83 \%$ (2 steps); (h) $\mathrm{H}_{2}, \mathrm{Pd}(\mathrm{OH})_{2} / \mathrm{C}$, $\mathrm{AcOH}$, acetone $-\mathrm{H}_{2} \mathrm{O}(1: 1), 100 \%$.

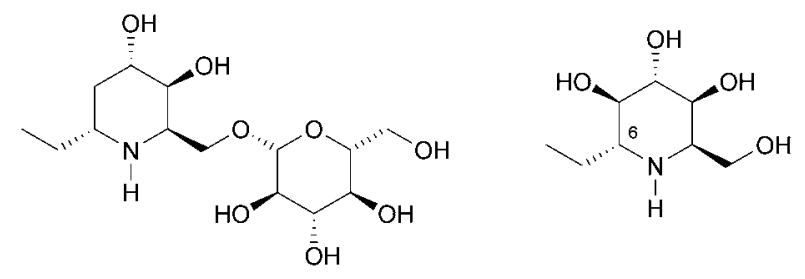

1-O- $\beta$-D-Glucopyranosyl-5-deoxyadenophorine (55) Adenophorine (56)

Fig. 8 Examples of naturally occurring $\alpha-1-C$-alkylated 1-deoxy-iminosugar glycosidase inhibitors.
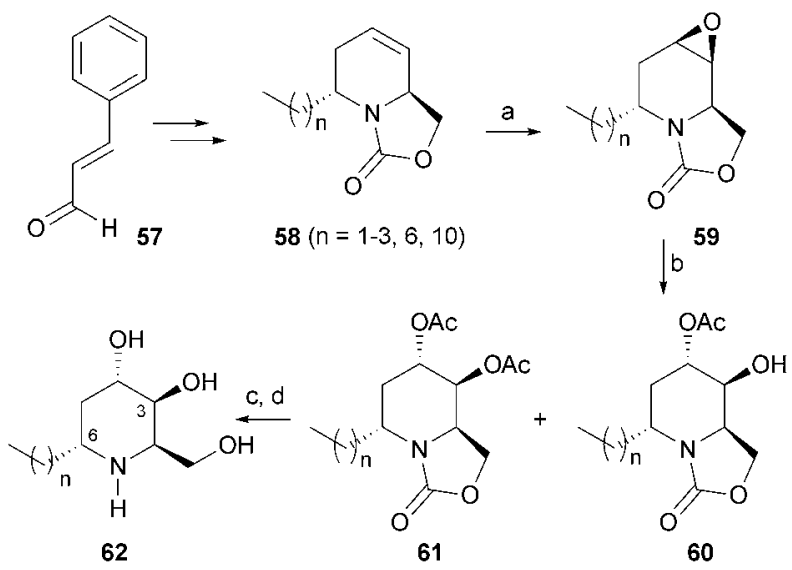

Scheme 9 Lebreton's synthesis of 5-deoxyadenophorine analogues. Reagents and conditions: (a) $m$-CPBA, $\mathrm{NaH}_{2} \mathrm{PO}_{4}, \mathrm{CH}_{2} \mathrm{Cl}_{2}, 0{ }^{\circ} \mathrm{C} \rightarrow \mathrm{rt}, 72$ h, 54-93\%; (b) $\mathrm{AcOH}, 100{ }^{\circ} \mathrm{C}, 17 \mathrm{~h}$; (c) $\mathrm{K}_{2} \mathrm{CO}_{3}, \mathrm{MeOH}, \mathrm{rt}, 3 \mathrm{~h}, 50-70 \%$ (2 steps); (e) $8 \mathrm{M} \mathrm{NaOH}-\mathrm{H}_{2} \mathrm{O}-\mathrm{MeOH}, 95^{\circ} \mathrm{C}, 24 \mathrm{~h}, 66-74 \%$.

of these systems is of note and has stimulated considerable interest.

Having previously completed the total synthesis of $\mathbf{5 5}$ in 2004, ${ }^{46}$ Lebreton and co-workers have recently reported the preparation of a series of racemic 5-deoxyadenophorine analogues from 1-Calkyl tetrahydropyridine $58(n=1-3,6,10)$ (Scheme 9). ${ }^{47}$ These 1,6-disubstituted piperidines were expediently accessed from transcinnamaldehyde (57) through a six-step sequence involving formation of the tetrahydropyridine ring by RCM. From 58, the trans-3,4-diol stereodiad was introduced via diastereoselective alkene epoxidation $(\mathrm{dr}=85: 15)$ and subsequent ring opening in acetic acid, which proceeded with complete regioselectivity to provide 60 and 61. After saponification of this mixture, hydrolysis of the oxazolidinone under more stringent conditions $(\mathrm{NaOH}$, $95{ }^{\circ} \mathrm{C}$ ) furnished 5-deoxyadenophorine analogues 62 . The corresponding cis-3,4-iminosugar series was also accessed through dihydroxylation of $\mathbf{5 8}$ rather than epoxidation. Preliminary biological evaluation of these novel iminosugar analogues revealed them to be weak $\alpha$-glucosidase inhibitors, although two cissubstituted compounds with $\mathrm{C}_{7}$ and $\mathrm{C}_{11}$ sidechains were found to be potent $\beta$-glucosidase inhibitors $\left(K_{\mathrm{i}}=60 \mu \mathrm{M}\right)$.

In related work, Lebreton has also completed the first total synthesis of the natural product $(+)$-adenophorine (56) (Scheme 10).$^{48}$ After conversion of (+)-Garner's aldehyde (64) to imine $\mathbf{6 5}$, addition of allylmagnesium bromide proceeded with reasonable diastereoselectivity to generate $\mathbf{6 6} \mathbf{b}$, thereby establishing the C6 stereocenter of the target. After protection of these 1,2-amino 
<smiles>CC#CCCCC(=O)C([N-])CO</smiles>

63<smiles>CC(C)(C)OC(=O)N1C(C=O)COC1(C)C</smiles>

64

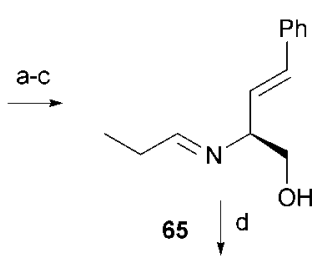

67a<smiles>C1CCCCC1</smiles><smiles>CC[C@H]1CC2O[C@H]2[C@H]2COC(=O)N12</smiles><smiles>CC[C@H]1C=C[C@@H](O)[C@@H]2COC(=O)N12</smiles>

69<smiles>[CH]N1C(CO)[C@@H](O)[C@H](O)[C@@H](O)[C@H]1CC</smiles>

(+)-Adenophorine (56)

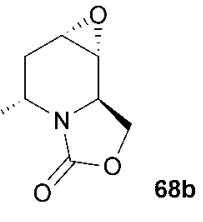<smiles>CC[C@H]1C2OC2[C@@H](OCc2ccccc2)C2COC(=O)N21</smiles>

$70 a$
OBn $/ \mathrm{l}, \mathrm{m}^{70 \mathrm{~b}}$

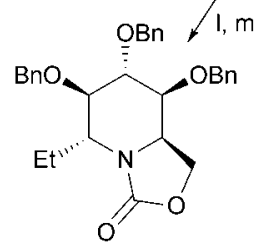

71

Scheme 10 Lebreton's total synthesis of (+)-adenophorine. Reagents and conditions: (a) diethyl benzylphosphonate, $n$-BuLi, THF, $-78^{\circ} \mathrm{C} \rightarrow$ rt. 14 h, $75 \%$; (b) $12 \mathrm{M} \mathrm{HCl}, \mathrm{MeOH}$, reflux, 4 h, 98\%; (c) EtCHO, $\mathrm{MgSO}_{4}$, THF, rt, $12 \mathrm{~h}$; (d) allylmagnesium bromide, THF, $\mathrm{Et}_{2} \mathrm{O},-78 \rightarrow-10^{\circ} \mathrm{C}, 6$ h, $87 \%, \mathrm{dr}=87: 13$; (e) CDI, $\mathrm{Et}_{3} \mathrm{~N}, \mathrm{CH}_{2} \mathrm{Cl}_{2}, 18$ h, $88 \%$; (f) Grubbs' 2ndgeneration catalyst ( $5 \mathrm{~mol} \%), \mathrm{CH}_{2} \mathrm{Cl}_{2}$, reflux, $1 \mathrm{~h}, 67 \mathbf{a}(74 \%)$, 67b $(9 \%)$; (g) DMDO, acetone, rt, 4 h, 68a, 60\%; (h) $\mathrm{Ph}_{2} \mathrm{Se}_{2}, \mathrm{NaBH}_{4}, \mathrm{EtOH}, \mathrm{rt}, 12$ h, $72 \%$; (i) $50 \% \mathrm{H}_{2} \mathrm{O}_{2}$, THF, rt, $2 \mathrm{~h}, 63 \%$; (j) $\mathrm{BnBr}, \mathrm{NaH}$, THF, rt, 12 h; (k) $m$-CPBA, $\mathrm{CH}_{2} \mathrm{Cl}_{2}, \mathrm{rt}, 72 \mathrm{~h}, 70 \mathrm{~b}\left(60 \%, 2\right.$ steps); (l) $1 \mathrm{M} \mathrm{H}_{2} \mathrm{SO}_{4}, \mathrm{H}_{2} \mathrm{O}-$ dioxane (1:1), $80^{\circ} \mathrm{C}, 12 \mathrm{~h}$; (m) BnBr, NaH, DMF, rt, $2 \mathrm{~h}, 60 \%$ (2 steps); (n) $8 \mathrm{M} \mathrm{NaOH}, \mathrm{MeOH}, 95^{\circ} \mathrm{C}, 48 \mathrm{~h}, 76 \%$; (o) $\mathrm{H}_{2}, \mathrm{Pd}(\mathrm{OH})_{2}, \mathrm{HCl}, \mathrm{EtOH}$, rt, $24 \mathrm{~h}, 100 \%$.

alcohols, formation of tetrahydropiperidine 70a was accomplished by ring-closing metathesis of the oxazolidinone mixture and chromatographic separation. The C3-C5 stereotriad present in adenophorine was now introduced in stepwise fashion via alkene expoxidation, regioselective ring opening to generate an allylic selenide, and selenoxide elimination to yield 69. $O$-Benzylation of this allylic alcohol and exo-face epoxidation using $m$-CPBA generated 70a with excellent facial control $(\mathrm{dr}=95: 5)$. Solvolysis of this epoxide proceeded with complete regiocontrol to yield 71, after bis- $O$-benzylation. Saponification of the oxazolidine ring and hydrogenolytic removal of the benzyl ethers then completed the synthesis of (+)-adenophorine (56).

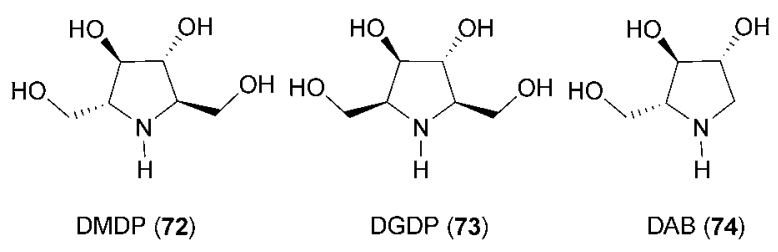

Fig. 9 Naturally occurring polyhydroxylated pyrrolidine-based glycosidase inhibitors: DMDP, DGDP and DAB.

\subsection{Pyrrolidines}

Polyhydroxylated pyrrolidine alkaloids, including 2,5-dideoxy-2,5imino-D-mannitol (DMDP, 72), 2,5-dideoxy-2,5-imino-D-glucitol (DGDP, 73), 1,4-dideoxy-1,4-imino-D-arabinitol (DAB-1, 74) are widespread, naturally occurring secondary sugar mimics, many of which have been found to be specific inhibitors of plant and mammalian glucosidases as well as antiviral agents (Fig. 9). ${ }^{49}$

Numerous syntheses of these targets have been reported in the literature, ${ }^{50}$ and while carbohydrates are appealing points of departure in these undertakings, the issue of regiocontrol as it pertains to hydroxyl group protection has proven to be a recurring challenge. In an effort to obviate this problem, Mellet and Fernandez have recently developed a method to selectively mask 1,2-diols as cyclic $o$-xylylene ethers and have successfully utilized this protecting group strategy in the total synthesis of DMDP (72) and DGDP (73) (Scheme 11). ${ }^{51}$ Commencing from protected D-fructose derivative 75, alkylation of the free hydroxyl group with $\alpha, \alpha^{\prime}$-dibromoxylene and selective hydrolysis of the 4,5-Oisopropylidene group provided 76. Treatment with sodium hydride in DMF then mediated ring closure to form $o$-xylylene ether 77 which, through double inversion, was converted to azide $\mathbf{7 8}$ in excellent overall yield. The synthesis of DMDP (72) was completed efficiently by removal of the acetonide group and submission of 1,2-diol 79 to catalytic hydrogenation. In the presence of $\mathrm{HCl}$, this process resulted in hydrogenolysis of the cyclic ether, azide reduction and, ultimately, stereoselective reductive amination of the latent $\gamma$-amino ketone.

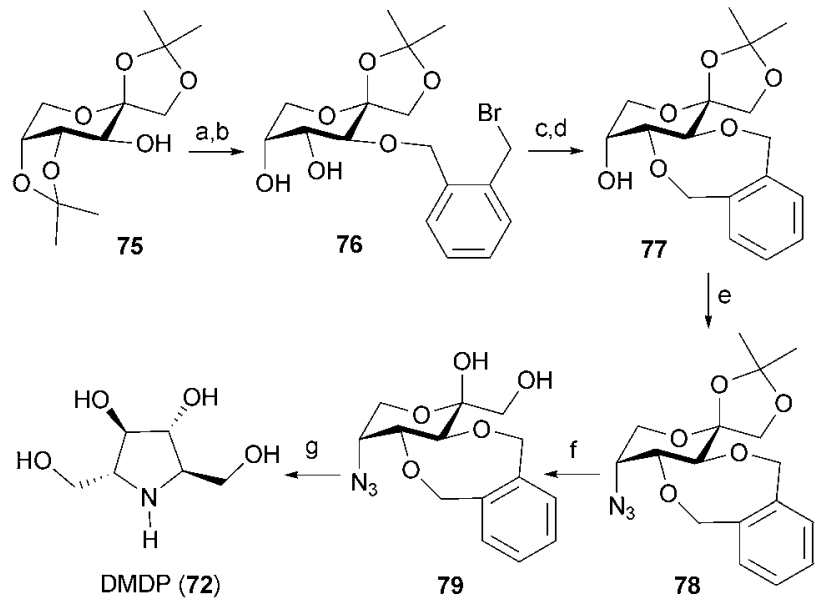

Scheme 11 Mellet and Fernandez's synthesis of DMDP. Reagents and conditions: (a) $\alpha, \alpha^{\prime}$-dibromoxylene, NaH, DMF, rt, $20 \mathrm{~min}, 91 \%$; (b) $60 \%$ aq. $\mathrm{AcOH}, 45^{\circ} \mathrm{C}, 2 \mathrm{~h}, 87 \%$; (c) $\mathrm{NaH}, \mathrm{DMF}$, rt, 15 min, $93 \%$; (d) $\mathrm{I}_{2}, \mathrm{PPh}_{3}$, imidazole, $\mathrm{PhCH}_{3}, 80{ }^{\circ} \mathrm{C}, 16 \mathrm{~h}, 98 \%$; (e) $\mathrm{NaN}_{3}, \mathrm{DMF}, 80^{\circ} \mathrm{C}, 12 \mathrm{~h}, 91 \%$; (f) TFA- $\mathrm{H}_{2} \mathrm{O}$ (9 : 1), rt, $30 \mathrm{~min}, 98 \%$; (g) $\mathrm{H}_{2}$ (4 bars), $\mathrm{Pd} / \mathrm{C}, \mathrm{HCl}, \mathrm{MeOH}-$ $\mathrm{H}_{2} \mathrm{O}, 24 \mathrm{~h}, 95 \%$. 


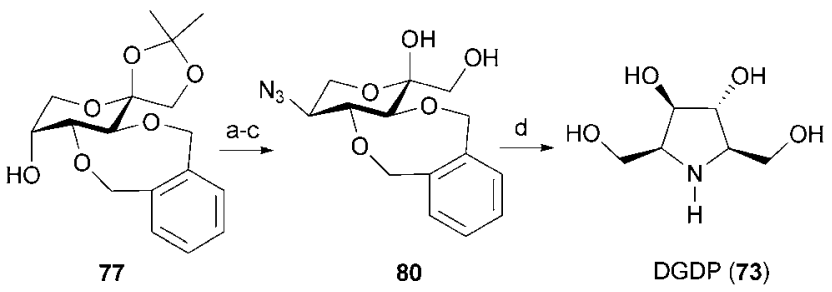

Scheme 12 Mellet and Fernandez's synthesis of DGDP. Reagents and conditions: (a) $\mathrm{Tf}_{2} \mathrm{O}$, pyridine, $\mathrm{CH}_{2} \mathrm{Cl}_{2}, \mathrm{rt}, 1 \mathrm{~h}$; (c) $\mathrm{NaN}_{3}, \mathrm{DMF}, \mathrm{rt}, 3 \mathrm{~h}$, $83 \%$ (2 steps); (c) TFA- $\mathrm{H}_{2} \mathrm{O}$ (9: 1), rt, $30 \mathrm{~min}, 98 \%$; (d) $\mathrm{H}_{2}$ (4 bars), $\mathrm{Pd} / \mathrm{C}$, $\mathrm{HCl}, \mathrm{MeOH}-\mathrm{H}_{2} \mathrm{O}, 24 \mathrm{~h}, 95 \%$.

Mellet and co-workers have also adapted their route to DMDP (72) for the preparation of DGDP (73) (Scheme 12). In this case, activation of the secondary hydroxyl group in 77 as a triflate ester and stereoinversion with azide provided diastereomer 80. Conversion of this material to the hydrochloride salt of DMDP (73) was accomplished as before, via acetonide hydrolysis and global reduction.
81<smiles>C=CC1CO1</smiles><smiles>O=C1NC(=O)c2ccccc21</smiles>

82<smiles>C=C[C@H](CO)N1C(=O)c2ccccc2C1=O</smiles>

83<smiles>C1C[C@H]2CC[C@H](C1)C2</smiles><smiles>C=CC(CO)N1C(=O)OC[C@H]1C=C</smiles><smiles>C=C[C@@H](CO)N1C(=O)OC[C@H]1C=C</smiles>

85b<smiles>O=C1OC[C@H]2C=CC(COc3ccccc3)N12</smiles>
86

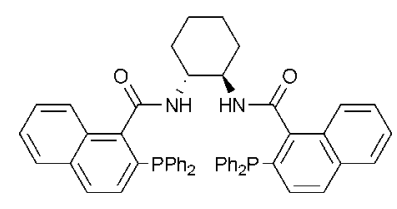

$(R, R)-89$

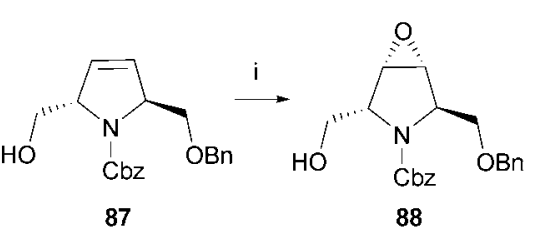

88

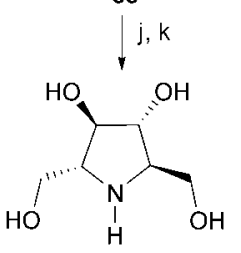

DMDP (72)
Scheme 13 Trost's synthesis of DMDP. Reagents and conditions: a) [ $\left(\eta^{3}-\right.$ $\left.\left.\mathrm{C}_{3} \mathrm{H}_{5}\right) \mathrm{PdCl}\right]_{2}(0.4 \mathrm{~mol} \%),(R, R)-89(1.2 \mathrm{~mol} \%), \mathrm{Na}_{2} \mathrm{CO}_{3}(1 \mathrm{~mol} \%)$, $\mathrm{CH}_{2} \mathrm{Cl}_{2}, \mathrm{rt}, 99 \%$, ee = 94\%; (b) ethylenediamine, EtOH, reflux, $84 \%$; (c) triphosgene, $\mathrm{NaHCO}_{3}$, toluene- $\mathrm{H}_{2} \mathrm{O}(1: 1), 0{ }^{\circ} \mathrm{C}, 85 \%$; (d) butadiene monoxide, $\left[\mathrm{Pd}_{2} \mathrm{dba}_{3}\right] \cdot \mathrm{CHCl}_{3}(1 \mathrm{~mol} \%),(R, R)-89(1.5 \mathrm{~mol} \%), \mathrm{DBU}(1$ $\mathrm{mol} \%$ ), $\mathrm{CH}_{2} \mathrm{Cl}_{2}, \mathrm{rt}, 91 \%, \mathrm{dr}=93: 7$; (e) $\mathrm{NaH}, \mathrm{BnBr}$, TBAI, THF, rt, $84 \%$; (f) Grubbs' second-generation catalyst (1.2 mol\%), $\mathrm{CH}_{2} \mathrm{Cl}_{2}, 40{ }^{\circ} \mathrm{C}$, 91\%; (g) $\mathrm{NaOH}, \mathrm{EtOH}-\mathrm{H}_{2} \mathrm{O}$ (3:1), reflux; (h) $\mathrm{BnOCOCl}, \mathrm{NaHCO}_{3}$, $\mathrm{Na}_{2} \mathrm{CO}_{3}, \mathrm{H}_{2} \mathrm{O}, 0{ }^{\circ} \mathrm{C}, 99 \%$, (2 steps); (i) $\mathrm{MeReO}_{3}(5 \mathrm{~mol} \%$ ), $\mathrm{CO}(\mathrm{N}-$ $\left.\mathrm{H}_{2}\right)_{2} \cdot \mathrm{H}_{2} \mathrm{O}_{2}, \mathrm{CH}_{2} \mathrm{Cl}_{2}, \mathrm{rt}, 76 \%$, dr $>25: 1$; (j) TFA, THF, $\mathrm{H}_{2} \mathrm{O}, 65^{\circ} \mathrm{C}$, $72 \%$; (k) $\mathrm{H}_{2}, \mathrm{Pd} / \mathrm{C}, \mathrm{HCl}, \mathrm{MeOH}, 96 \%$.

The first report of a catalytic enantioselective synthesis of DMDP (72) was made in 2006, by Trost and co-workers, ${ }^{52}$ who employed consecutive palladium-catalysed dynamic kinetic asymmetric transformations (DYKAT) to generate trans-2,5dihydropyrrole 86, a key intermediate for the preparation of a number of alkaloids (Scheme 13). In this case, $\mathrm{N}$-alkylation of phthalimide $(\mathbf{8 2})$ with butadiene oxide $(\mathbf{8 1})$ proceeded with excellent regio- and enantioseletivity to form $\mathbf{8 3}$. After a two-step conversion of this material to oxazolidinone 84, a second Pd-catalyzed DYKAT reaction with butadiene oxide yielded a chromatographically separable mixture of dienes $\mathbf{8 5}$. $O$-Benzylation, ring closure using Grubbs' second-generation catalyst, oxazolidinone hydrolysis and $N$-protection then provided dihydropyrrole 87. Hydroxyl-directed epoxidation of this alkene using catalytic methyltrioxorhenium led to the formation of $\mathbf{8 8}$ which, upon acid-mediated epoxide ring opening and hydrogenolysis, afforded DMDP (72) in 11 steps and $22 \%$ overall yield.

Employing a chiral-pool approach, Madsen and Lauritsen have reported a concise approach to DAB (74) which features the<smiles>OCC1(O)OC[C@@H](O)[C@H](O)[C@H]1O</smiles>

90<smiles>[Z4]N1[C@H](O)[C@@H](O)[C@@H](CO)N1Cl</smiles>

Scheme 14 Madsen and Lauritsen's synthesis of DAB. Reagents and conditions: (a) $\mathrm{MeOH}, \mathrm{H}_{2} \mathrm{SO}_{4}, \mathrm{rt}$; (b) $\mathrm{I}_{2}, \mathrm{PPh}_{3}$, imidazole, THF, $65^{\circ} \mathrm{C}$; (c) $\mathrm{BnOC}(\mathrm{NH}) \mathrm{CCl}_{3}$, TfOH, dioxane, $0{ }^{\circ} \mathrm{C}$; (d) $\mathrm{Zn}$, THF, $\mathrm{H}_{2} \mathrm{O}$, ultrasound, $40{ }^{\circ} \mathrm{C}$; (e) $\mathrm{O}_{3}, \mathrm{MeOH}, \mathrm{CH}_{2} \mathrm{Cl}_{2},-78{ }^{\circ} \mathrm{C}$, then $\mathrm{Me}_{2} \mathrm{~S}$, rt; (f) $\mathrm{BnNH}_{2}$, $\mathrm{NaCNBH}_{3}, \mathrm{AcOH}, 3 \AA$ A MS, THF, rt, 93a (44\%, two steps); (g) $\mathrm{H}_{2}, \mathrm{Pd} / \mathrm{C}$, $\mathrm{HCl}, \mathrm{MeOH}, \mathrm{rt}, 74 \%$.

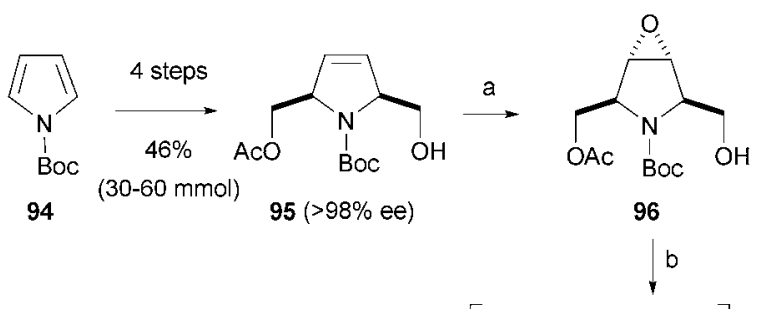

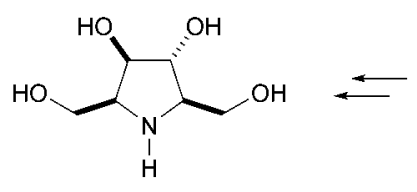

DGDP (73)

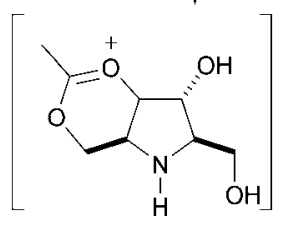

97
Scheme 15 Donohoe's synthesis of DGDP. Reagents and conditions: (a) $\mathrm{CF}_{3} \mathrm{COCH}_{3}$, Oxone, $\mathrm{NaHCO}_{3}, \mathrm{CH}_{3} \mathrm{CN}-\mathrm{H}_{2} \mathrm{O}$, EDTA, $0{ }^{\circ} \mathrm{C}, 94 \%$; (b) $\mathrm{BF}_{3} \cdot \mathrm{OEt}_{2}, \mathrm{CH}_{2} \mathrm{Cl}_{2}, 0{ }^{\circ} \mathrm{C} \rightarrow \mathrm{rt}$; then $\mathrm{MeOH}, 78 \%$. 
zinc-mediated fragmentation of iodofuranoside 91 (Scheme 14). ${ }^{53}$ D-Fructose (90) was converted to 91 via a sequence of Fischer glycosylation with methanol, selective iodination of the primary alcohol and per- $O$-benzylation using Bundle's reagent. Upon sonication in the presence of zinc, 91 underwent reductive fragmentation to afford unsaturated ketone $\mathbf{9 2}$ in good yield. In order to complete the synthesis of DAB, this alkene was ozonized and the resulting 1,4-dicarbonyl compound subjected to reductive amination with benzylamine in the presence of $\mathrm{NaBH}_{3} \mathrm{CN}$ and acetic acid. Unfortunately, this cyclization proceeded with poor diastereoselectivity and yielded $N$-benzyl-DAB derivative 93a and its L-xylo epimer 93b in a 5:2 ratio. After chromatographic separation, hydrogenolysis of $\mathbf{9 3 a}$ gave the hydrochloride salt of DAB (74) in seven steps and 11\% overall yield from D-fructose.

Donohoe and co-workers has developed an elegant and highly efficient synthesis of (+)-DGDP (73) ${ }^{54}$ which makes use of their well-established methodology involving the partial Birch reduction of heterocycles (Scheme 15). ${ }^{55}$ In this work, preparation of DGDP commenced from enantiopure monoacetate 95, which was obtained from $N$-Boc pyrrole (94) in four steps. Epoxidation of this pyrroline using methyltrifluoromethyl dioxirane proceeded efficiently with excellent facial selectivity to yield $\mathbf{9 6}$. Lewis acid-mediated ring opening of this epoxide now proceeded with complete regio- and stereocontrol as a result of the participation of the proximal $O$-acetyl group. Concomitant loss of the $N$-Boc group and methanolysis of the putative dioxonium ion intermediate 97 then provided DGDP (73) in 6 steps and 34\% overall yield.

\subsection{Pyrrolizidines}

Noteworthy members of this family of plant-derived, polyhydroxylated natural products include (+)-australine (98), (+)-casuarine (99), hyacinthacine $A_{2}(\mathbf{1 0 0})$, hyacinthacine $A_{1}$ (101) and (+)-alexine (102) (Fig. 10). Notwithstanding their unifying pyrrolizidine core structure, these alkaloids display a diverse range of differing biological activities, for which reason they remain popular synthetic targets. (+)-Australine (98), isolated from Castenospermine australe by Moleneux and co-workers, ${ }^{56}$ is among of the most important members of this group of compounds, since it not only potently inhibits $\alpha$-amyloglucosidase and glycoprotein processing ${ }^{57}$ but displays anti-HIV activity. ${ }^{58}$

Trost and co-workers have reported an elegant synthesis of australine (98) which features the Pd-catalyzed DYKAT reaction of oxazolidinone 104 with butadiene oxide (Scheme 16). ${ }^{59}$ Notably, this $N$-alkylation proceeded with excellent (catalystcontrolled) diastereoselectivity to provide $\mathbf{1 0 5}$ in near-quantitative yield. Ring-closing metathesis of this material using Grubbs' second-generation catalyst then furnished 3-pyrroline 106 which, after protection of the primary alcohol, underwent regioselective hydroboration-oxidation to generate the primary alcohol. The remaining alkene was epoxidized with methyl trifluoromethyl dioxirane and compound $\mathbf{1 0 7}$ then solvolyzed in benzyl alcohol to provide 108, the product of oxazolidinone hydrolysis and epoxide ring-opening. Having established all stereocenters of the target, the synthesis of australine hydrochloride (109) was completed by formation of the pyrrolizidine ring system and removal of the benzyl ethers using $\mathrm{PdCl}_{2}$ as the hydrogenation catalyst and source of $\mathrm{HCl}$.

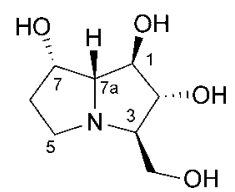

(+)-Australine (98)

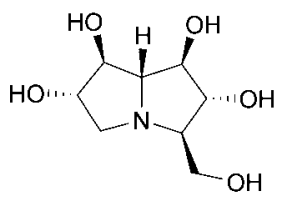

(+)-Casuarine (99)

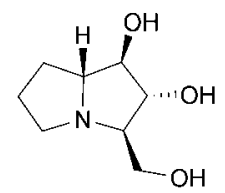

(+)-Hyacinthacine $A_{2}(\mathbf{1 0 0})$

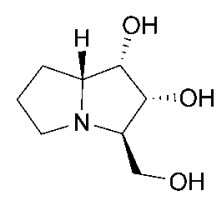

(+)-Hyacinthacine $A_{1}(101)$

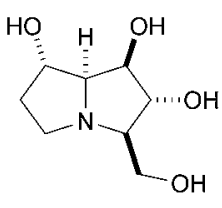

$(+)$-Alexine (102)
Fig. 10 Structures of selected, naturally occurring C3-alkylated pyrrolizidine alkaloids, which display $\alpha$-glucosidase inhibitory activity.
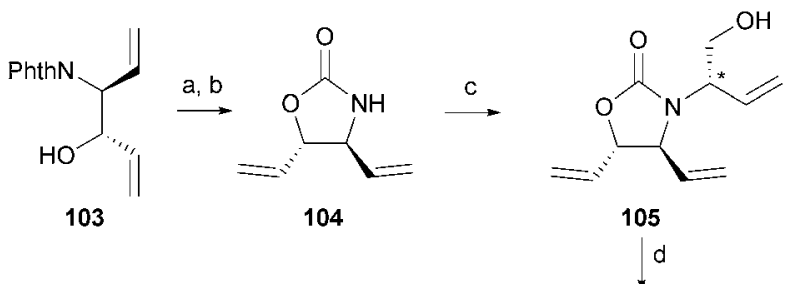<smiles></smiles>

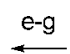<smiles>C=C[C@@H]1OC(=O)N2[C@@H](CO)C=C[C@H]12</smiles>

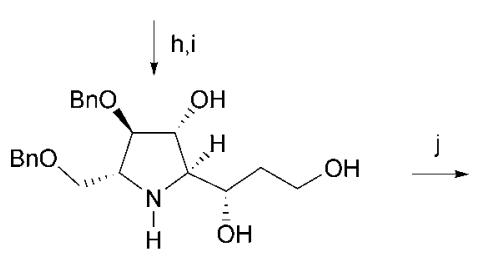

108
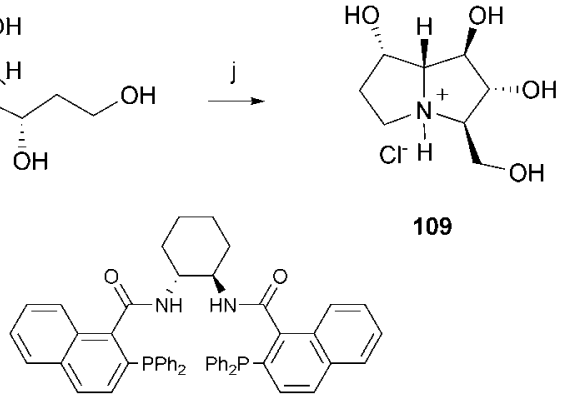

109

Scheme 16 Trost's total synthesis of (+)-australine. Reagents and conditions: (a) $\mathrm{H}_{2} \mathrm{~N}\left(\mathrm{CH}_{2}\right)_{2} \mathrm{NH}_{2}$, EtOH, $96 \%$; (b) triphosgene, pyridine, $\mathrm{CH}_{2} \mathrm{Cl}_{2}, 78 \%$; (c) $\left[\mathrm{Pd}_{2} \mathrm{dba}_{3}\right] \cdot \mathrm{CHCl}_{3}(0.5 \mathrm{~mol} \%),(R, R)-89(1.5 \mathrm{~mol} \%)$, DBU (10 mol\%), $\mathrm{CH}_{2} \mathrm{Cl}_{2}, 99 \%, \mathrm{dr}=95: 5$; (d) Grubbs' second-generation catalyst ( $1 \mathrm{~mol} \%$ ), $\mathrm{CH}_{2} \mathrm{Cl}_{2}, 77 \%$; (e) $\mathrm{BnOC}(\mathrm{NH}) \mathrm{CCl}_{3}, \mathrm{TfOH}, 94 \%$; (f) 9-BBN, THF; $\mathrm{NaBO}_{3} \cdot \mathrm{H}_{2} \mathrm{O}, \mathrm{H}_{2} \mathrm{O}, 74 \%$; (g) Oxone, $\mathrm{CF}_{3} \mathrm{COCH}_{3}$, $\mathrm{NaHCO}_{3}, \mathrm{MeCN}_{-} \mathrm{H}_{2} \mathrm{O}$, EDTA, $0{ }^{\circ} \mathrm{C}, 67 \%$; (h) Dowex $1 \mathrm{X} 8-50, \mathrm{BnOH}$, $100{ }^{\circ} \mathrm{C}, 51 \%$; (i) $\mathrm{MsCl}, \mathrm{Et}_{3} \mathrm{~N}, \mathrm{CH}_{2} \mathrm{Cl}_{2}, 74 \%$; (j) $\mathrm{H}_{2}, \mathrm{PdCl}_{2}, \mathrm{MeOH}, 98 \%$. 


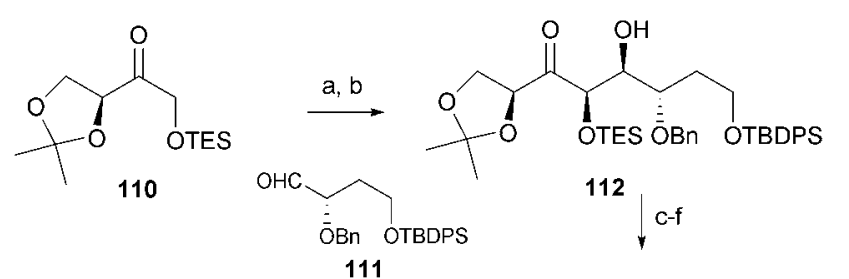

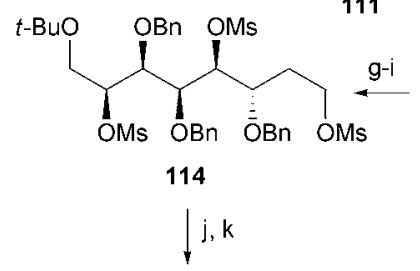

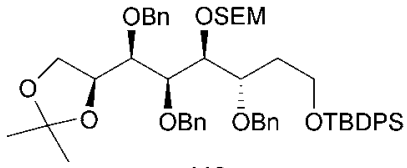

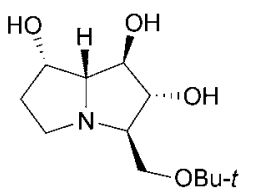

115

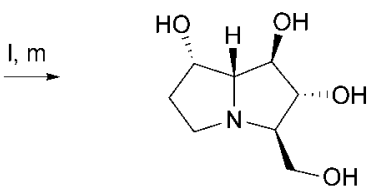

(+)-Australine (98)
Scheme 17 Marco and Falamor's total synthesis of (+)-australine. Reagents and conditions: (a) (cyclohexyl) ${ }_{2} \mathrm{BCl}, \mathrm{Et}_{3} \mathrm{~N}, \mathrm{Et}_{2} \mathrm{O}, 0{ }^{\circ} \mathrm{C}$; (b) 113, $72 \%$; (c) $\mathrm{SEMCl}, i-\mathrm{Pr}_{2} \mathrm{NEt}, \mathrm{CH}_{2} \mathrm{Cl}_{2}$, rt, $24 \mathrm{~h}, 75 \%$; (d) $\mathrm{LiBH}_{4}, \mathrm{Et}_{2} \mathrm{O},-90^{\circ} \mathrm{C}$, $80 \%$; (e) DDQ, THF- $\mathrm{H}_{2} \mathrm{O}$, rt, 24 h, 74\%; (f) BnBr, NaH, THF, 4 h, $40{ }^{\circ} \mathrm{C}$, $80 \%$; (g) $\mathrm{MeMgBr}, \mathrm{PhCH}_{3}-\mathrm{Et}_{2} \mathrm{O}, 16$ h, 77\%; (h) TBAF, THF, rt, 1 h, $97 \%$; (i) $\mathrm{MsCl}, \mathrm{Et}_{3} \mathrm{~N}, \mathrm{CH}_{2} \mathrm{Cl}_{2}, \mathrm{rt}, 2 \mathrm{~h}$; (j) $\mathrm{BnNH}_{2}, \mathrm{NaI}, \mathrm{DMSO}, 80^{\circ} \mathrm{C}, 24 \mathrm{~h}, 60 \%$ (2 steps); (k) $\mathrm{H}_{2}, \mathrm{Pd}(\mathrm{OH})_{2}, \mathrm{rt}, 2 \mathrm{~d}$; (l) TFA, $\mathrm{CH}_{2} \mathrm{Cl}_{2}, \mathrm{rt}, 15 \mathrm{~h}$; (m) $\mathrm{NH}_{4} \mathrm{OH}$, $78 \%$ (3 steps).

A stereocontrolled, convergent synthesis of (+)-australine (98) has also been reported by Marco, Falomir and co-workers, who employ an aldol-based strategy to rapidly establish the 5 stereocenters present in the target molecule (Scheme 17). ${ }^{60}$ In this endevour, the $Z$-boron enolate derived from L-erythrulose derivative 110 underwent reaction with $\alpha$-alkoxyaldehyde 111 to generate adduct $\mathbf{1 1 2}$ as a single diastereoisomer. After protection of the secondary alcohol and $s y n$-selective reduction of the ketone, a series of protecting and functional group manipulations led to trimesylate 114. Generation of the bicyclic pyrrolizidine system 115 was now accomplished by means of a three-step sequence of $\mathrm{S}_{\mathrm{N}} 2$ displacements, triggered by benzylamine. Notably, this process also leads to the concomitant $N$-benzylation of the putative quaternary ammonium ion intermediate. The synthesis of (+)-australine (98) was completed by hydrogenolysis of the benzyl ether and acid-catalyzed removal of the tert-butyl ether. Employing this aldol strategy, Marco and co-workers have recently completed the stereoselective synthesis of hyacinthacine $\mathrm{A}_{2}$, hyacinthacine $\mathrm{A}_{3}$ and 5-epi-hyacinthacine $\mathrm{A}_{3}{ }^{61}$

Using the zinc-mediated fragmentation strategy developed for their synthesis of 1,4-dideoxy-1,4-imino-D-arabinitol (DAB), Madsen and Lauritsen have reported a formal synthesis of australine (98), which features generation of the pyrrolizidine core structure through the transannular ring closure of an eightmembered aminoepoxide. ${ }^{53}$ This approach has also been gainfully exploited by Madsen and co-workers in their 2009 synthesis of castanospermine (vide infra).

Isolated from the bark of Casuarina equisetifolia and from the leaves of Eugenia jambolana, (+)-casuarine (99) and its 6-O- $\alpha-$ glucoside 123 were originally found to be specific inhibitors of

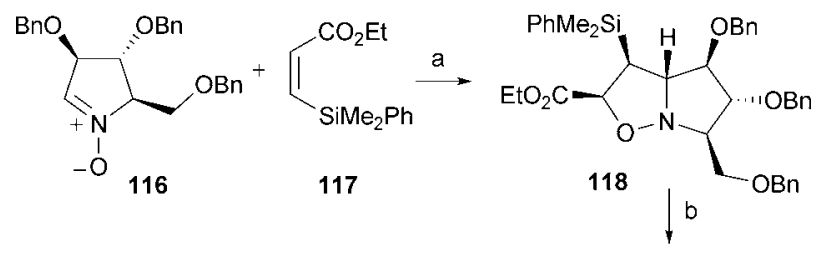<smiles>OC[C@H]1[C@@H](O)[C@H](O)[C@@H]2[C@@H](O)[C@@H](O)CN12</smiles>

(+)-Casuarine (99)

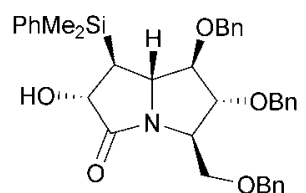

119
Scheme 18 Goti's total synthesis of (+)-casuarine. Reagents and conditions: (a) $\mathrm{CH}_{2} \mathrm{Cl}_{2}, \mathrm{rt}, 36 \mathrm{~h}, 79 \%$; (b) $\mathrm{Zn}, \mathrm{AcOH}-\mathrm{H}_{2} \mathrm{O}, 60-65^{\circ} \mathrm{C}, 5 \mathrm{~h}, 93 \%$; (c) $\mathrm{Hg}\left(\mathrm{CF}_{3} \mathrm{CO}_{2}\right)_{2}, \mathrm{AcOH}, \mathrm{AcOOH}, \mathrm{CHCl}_{3}, 76 \%$; (d) $\mathrm{LiAlH}_{4}, \mathrm{THF}$, reflux, 78\%; (e) $\mathrm{H}_{2}, \mathrm{Pd} / \mathrm{C}, \mathrm{MeOH}, \mathrm{HCl}, 100 \%$.

fungal glucoamylase from Aspergillus niger $\left(\mathrm{IC}_{50}=0.7\right.$ and $1.1 \mu \mathrm{M}$, respectively). ${ }^{62}$ These important alkaloids have most recently been prepared by Goti and co-workers, who employed a stereoselective nitrone-alkene cycloaddition to establish the C6, C7 and C7a stereocenters of the pyrollizidine framework in a single step (Scheme 18). ${ }^{63}$ Thus, reaction of nitrone 116 with disubstituted $(Z)$-vinylsilane 117 proceeded with the anticipated regioselectivity to yield $118 .{ }^{64}$ Reductive cleavage of this isoxazolidine with $\mathrm{Zn}$ in acetic acid afforded lactam 119 which,
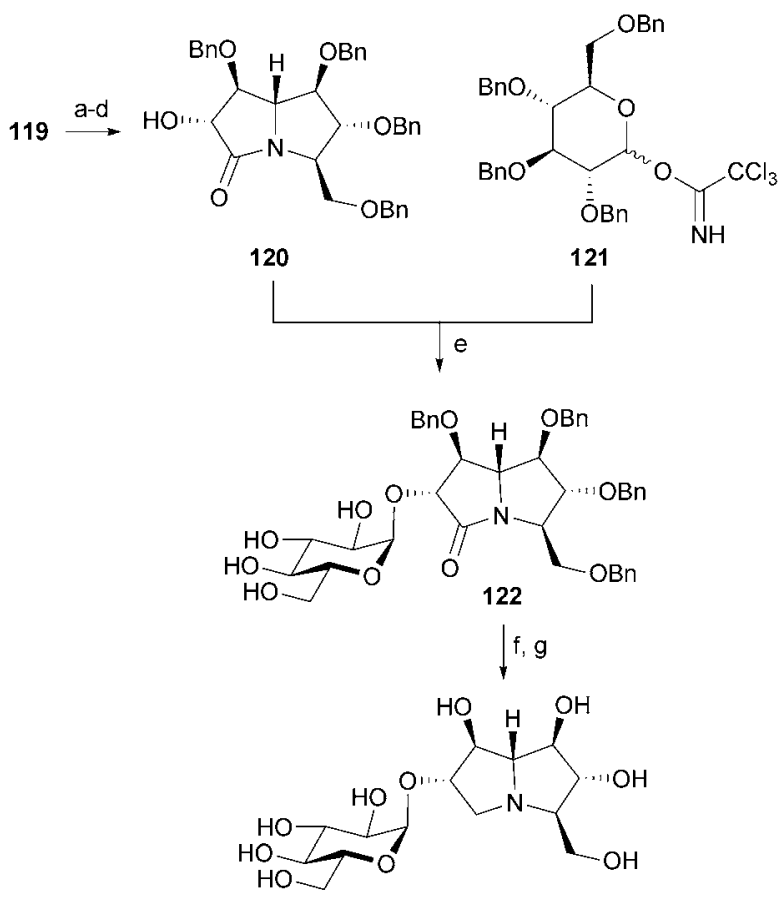

(+)-Casuarine 6-O- $\alpha$-glucoside (123)

Scheme 19 Goti's synthesis of (+)-casuarine 6-O- $\alpha$-glucoside. Reagents and conditions: (a) $\mathrm{Ac}_{2} \mathrm{O}$, pyridine, $\mathrm{rt}, 15 \mathrm{~h}, 100 \%$; (b) $\mathrm{Hg}\left(\mathrm{CF}_{3} \mathrm{CO}_{2}\right)_{2}$, $\mathrm{AcOH}, \mathrm{AcOOH}, \mathrm{CHCl}_{3}, 82 \%$; (c) $\mathrm{BnOC}(=\mathrm{NH}) \mathrm{CCl}_{3}, \mathrm{CF}_{3} \mathrm{SO}_{3} \mathrm{H}, \mathrm{Et}_{2} \mathrm{O}$, rt, 3 h; (d) Ambersep 900 ( $\mathrm{OH}^{-}$form), $\mathrm{MeOH}, \mathrm{rt}, 15 \mathrm{~h}, 75 \%$ (2 steps); (e) TMSOTf, $\mathrm{Et}_{2} \mathrm{O},-20{ }^{\circ} \mathrm{C}, 40 \mathrm{~min}, 72 \%$; (f) $\mathrm{LiBH}_{4}, \mathrm{BH}_{3} \cdot \mathrm{THF}$, THF, $23{ }^{\circ} \mathrm{C}, 3 \mathrm{~d}, 68 \%$; (g) $\mathrm{H}_{2}, \mathrm{Pd} / \mathrm{C}, \mathrm{MeOH}, \mathrm{HCl}, 77 \%$. 
through Tamao-Fleming oxidation of the $\mathrm{C}-\mathrm{Si}$ bond, lactam reduction and catalytic hydrogenolysis, was converted to casuarine (99).

Goti's synthesis of casuarine glucoside $\mathbf{1 2 3}$ commenced from lactam 119, which was advanced through 4 steps to compound 120, as shown in Scheme 19. Glycosylation of this secondary alcohol using trichloroacetamidate glycosyl donor $\mathbf{1 2 1}$ was mediated by catalytic TMSOTf and proceeded diastereoselectively to provide $\alpha$-anomer $\mathbf{1 2 2}$ in high yield. Finally, reduction of $\mathbf{1 2 2}$ with excess of $\mathrm{LiBH}_{4}$ in combination with $\mathrm{BH}_{3} \cdot \mathrm{THF}$ and subsequent hydrogenolysis generated target 123. Inhibition and docking studies subsequently carried out on casuarine (99) by Rose with the $N$-terminal domain of human intestinal maltase-glucoamylase (ntMGAM) have shown this is compound to a potent inhibitor with a $K_{\mathrm{i}}$ of $0.45 \mu \mathrm{M} .^{63}$ While glucoside 123 was found to be a significantly less active inhibitor of ntMGAM, it is a very potent $\left(K_{\mathrm{i}}=12 \mathrm{nM}\right)$ inhibitor of Tre37A, a periplasmic trehalase from Escherichia coli.

Utilizing DMDP derivative $\mathbf{1 2 4}$ as their starting point, Izquierdo and co-workers have developed a concise stereoselective route to (+)-casuarine (99) and its 6,7-bis-epi isomer 127 (Scheme 20). ${ }^{65}$ Advanced intermediate 124 was converted to 125 , following a three-step sequence of carbamate protection, primary alcohol oxidation and Wittig homologation. Dihydroxylation of this unsaturated ester then served to introduce the C6 and C7 stereocenters of the target molecule, although the diastereoselectivity in this case proved to be rather low $(\mathrm{dr}=2.2: 1)$ and highly

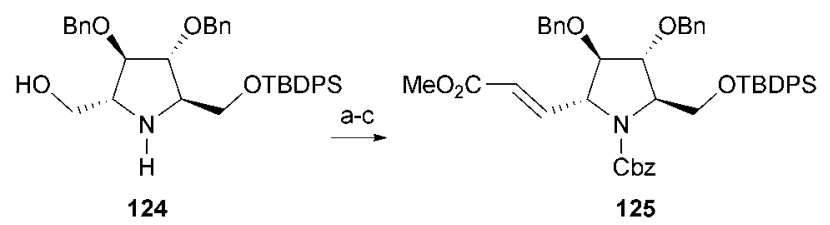

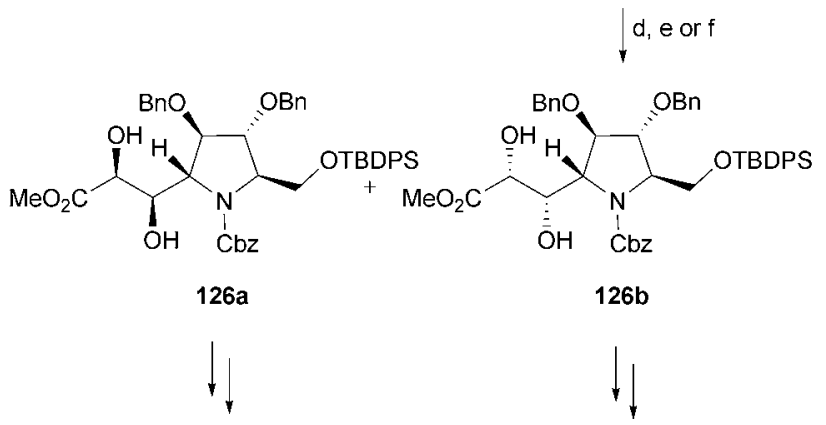

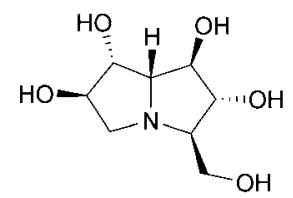

6,7-di-epi-(+)-Casuarine (127)

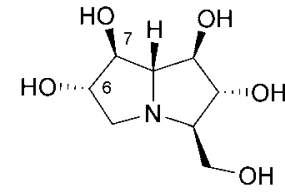

(+)-Casuarine (99)
Scheme 20 Izquierdo's total synthesis of 6,7-bis-epi-(+)-casuarine and (+)-casuarine. Reagents and conditions: (a) $\mathrm{CbzCl}, \mathrm{K}_{2} \mathrm{CO}_{3}$, acetone, $\mathrm{rt}, 3$ h, 93\%; (b) TPAP, NMO, $4 \AA$ A MS, $\mathrm{CH}_{2} \mathrm{Cl}_{2}$, rt, 1 h; (c) $\mathrm{Ph}_{3} \mathrm{P}=\mathrm{CHCO}_{2} \mathrm{Me}$, $\mathrm{CH}_{2} \mathrm{Cl}_{2}, \mathrm{rt}, 48 \mathrm{~h}, 85 \%$ (2 steps); (d) $\mathrm{OsO}_{4}, \mathrm{NMO}$, acetone- $\mathrm{H}_{2} \mathrm{O}$ (8: 1), rt, $30 \mathrm{~h}, 88 \%, \mathrm{dr}=1: 1$ (e) DHQ-CLB, NMO, acetone- $\mathrm{H}_{2} \mathrm{O}(5: 1), \mathrm{rt}, 48 \mathrm{~h}$, $85 \%, \mathrm{dr}=1: 2.2$; (f) DHQD-CLB, NMO, acetone- $\mathrm{H}_{2} \mathrm{O}(5: 1), \mathrm{rt}, 48 \mathrm{~h}$, $92 \%, \mathrm{dr}=2: 1$. dependant on the method/ligands employed. After separation of 126a and 126b, ring closure, lactam reduction, and further protecting group manipulations individually generated $(+)$-casuarine (99) and 6,7-bis-epi-casurine (127).

In 2006, Fleet and co-workers reported the isolation and total synthesis of the naturally occurring $\beta$-glucosidase inhibitor 3-epicasuarine (135) (Scheme 21). ${ }^{66}$ In addition, these authors also adapted this synthetic route to encompass casaurine (99) itself. Embarking from D-gluconolactone (128), this inexpensive starting material was converted through a five-step, four-pot sequence to allylic azide $\mathbf{1 3 0}$ on a multigram scale. In common with
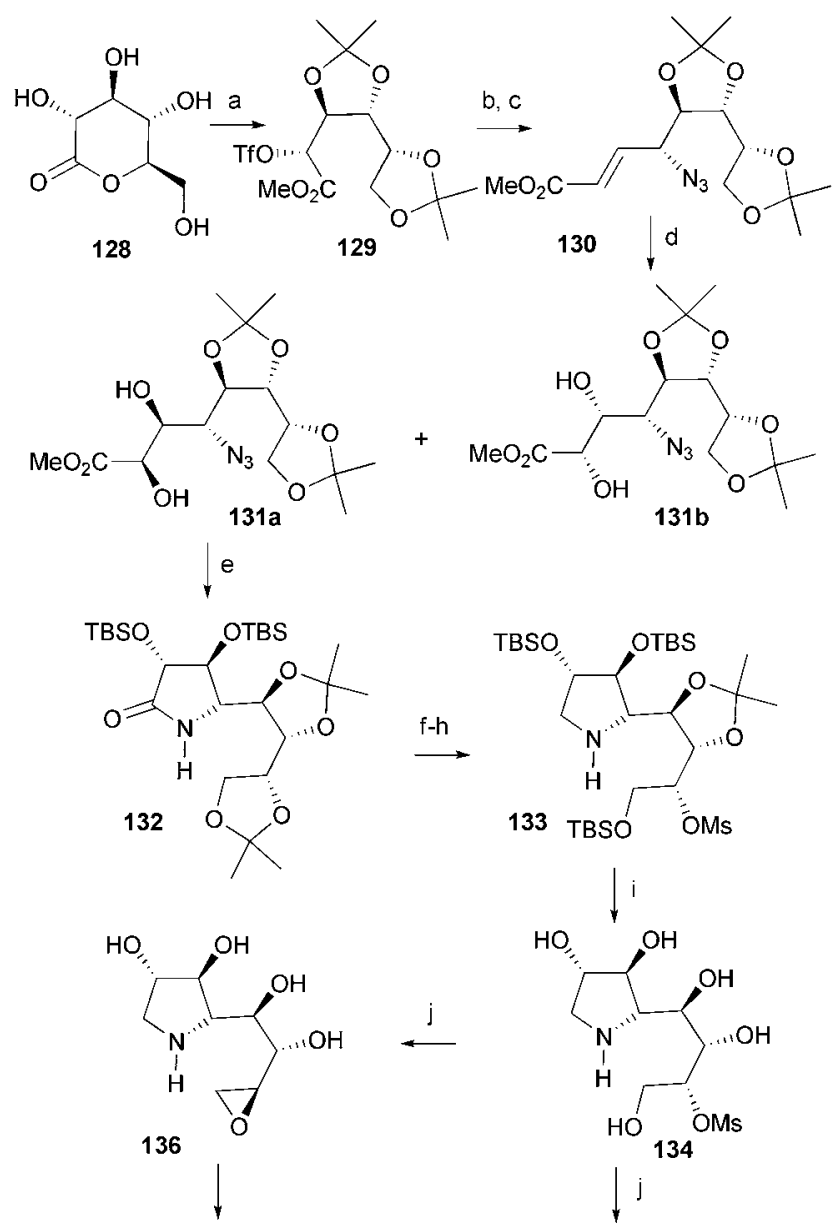

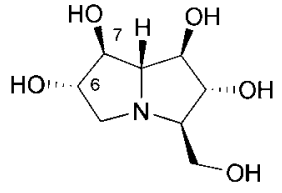

$(+)$-Casuarine (99)

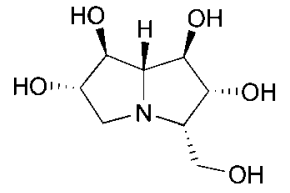

3-epi-Casuarine (135)
Scheme 21 Fleet's total synthesis of (+)-casuarine and 3-epi-casuarine. Reagents and conditions: (a) $\mathrm{Me}_{2} \mathrm{C}(\mathrm{OMe})_{2}, p$ - $\mathrm{TsOH}, \mathrm{MeOH}$; then $\left(\mathrm{CF}_{3} \mathrm{SO}_{2}\right)_{2} \mathrm{O}$, pyridine, $\mathrm{CH}_{2} \mathrm{Cl}_{2}, 72 \%$; (b) $\mathrm{NaN}_{3}$, DMF, 97\%; (c) DIBAL$\mathrm{H},-78{ }^{\circ} \mathrm{C}$; then $\mathrm{Ph}_{3} \mathrm{P}=\mathrm{CHCO}_{2} \mathrm{Me}, \mathrm{PhCH}_{3}, 75 \%$ (2 steps); (d) $\mathrm{OsO}_{4}$, NMO, $t$ - BuOH- $\mathrm{H}_{2} \mathrm{O}, 72 \%$; (e) $\mathrm{H}_{2}, \mathrm{Pd} / \mathrm{C}$, THF; then $\mathrm{PhCH}_{3}$, heat; then TBSCl, imidazole, THF, $70 \%$ (3 steps); (f) $60 \% \mathrm{AcOH}, \mathrm{H}_{2} \mathrm{O}-\mathrm{MeOH}$, $69 \%$; (g) $\mathrm{TBSCl}$, pyridine; then $\mathrm{MeSO}_{2} \mathrm{Cl}, \mathrm{Et}_{3} \mathrm{~N}, \mathrm{CH}_{2} \mathrm{Cl}_{2}, 66 \%$; (h) $\mathrm{BH}_{3} \cdot \mathrm{THF}$, THF, $57 \%$; (i) $\mathrm{CF}_{3} \mathrm{CO}_{2} \mathrm{H}-\mathrm{H}_{2} \mathrm{O}$ (9 : 1); (j) NaOAc, $\mathrm{H}_{2} \mathrm{O}, 89 \%$ (2 steps). 
Izquierdo's casuarine synthesis, introduction of the C6/7 stereodiad was accomplished through dihydroxylation, which gave a $4: 1$ mixture of 131a and 131b. Isomer separation was achieved in this case, after azide reduction, lactamization and diol silylation. Through a number of steps, compound $\mathbf{1 3 2}$ was converted to pentahydroaminomesylate 134, which upon exposure to sodium acetate underwent cyclization to yield 3-epi-casuarine (135) with a $6 \%$ overall yield. In this case, a small quantity $(<5 \%)$ of casaurine (99) was also isolated and is thought to arise through the competitive formation and cyclization of epoxide $\mathbf{1 3 6}$.

3-epi-Casuarine has also attracted the attention of Chmielewski and co-workers, who have recently developed a [2+3]cycloaddition-based route to 3-epi-1-homocasuarine (142) and analogues, 140 and 141 (Scheme 22). ${ }^{67}$ The key transformation in this work involves the 1,3-dipolar cycloaddition of nitrone 137 and $2(5 H)$-furanone 138, which proceeds with complete diastereo- and regioselectivity ${ }^{68}$ Through a sequence featuring lactone reduction, $\mathrm{N}-\mathrm{O}$ bond scission and intramolecular alkylation of the nitrogen atom, 139 was converted to 140,141 and 142 .

Isolated from the bulbs of the grape hyacinth (Muscari armeniacum) by Asano co-workers, hyacinthacine $\mathrm{A}_{2}(\mathbf{1 0 0})$ is a selective inhibitor of amyloglucosidase (Aspergillus niger) with an $\mathrm{IC}_{50}$ value of $8.6 \mu \mathrm{M} .^{69}$ Blechert and co-workers have developed a short and convergent synthesis of $\mathbf{1 0 0}$ in which the trans-fused pyrrolizidine core is constructed through a double reductive cyclization (Scheme 23). ${ }^{70}$ Assembly of the skeleton of 100 commenced with the stereoselective cross-metathesis (CM) of enone 143 and vinylglycine derivative 144 and using the Hoveyda-Blechert ruthenium catalyst. Sharpless enantioselective dihydroxylation of the resulting enone was followed by a one-pot, three-step hydrogenation procedure to generate hydrochloride salt 147. Treatment with Amberlite $\left(\mathrm{OH}^{-}\right.$form $)$ then afforded hyacinthacine $A_{2}(\mathbf{1 0 0})$ in $39 \%$ yield. Blechert has also employed the CM reaction of a 2-vinyl-3-alkoxypyrrolidine derivative in the preparation of 7a-epi-7-deoxycasuarine. ${ }^{71}$

The total synthesis of (+)-hyacinthacine $\mathrm{A}_{2}(\mathbf{1 0 0})$ has also been reported by Py, who has made use of a $\mathrm{SmI}_{2}$-induced reductive coupling reaction to simultaneously assemble the carbon framework and establish the $\mathrm{C} 7 \mathrm{a}$ stereocenter of the target

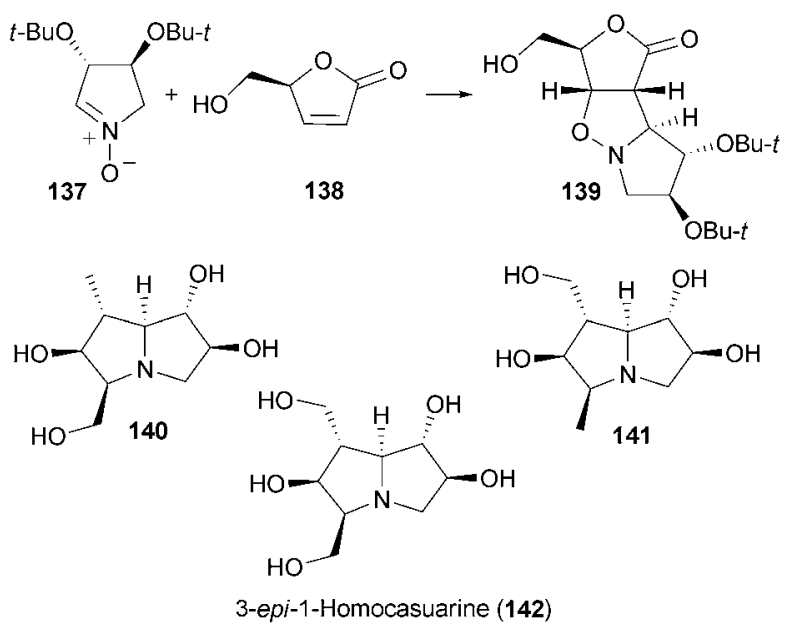

Scheme 22 Chmielewski's 1,3-dipolar cycloaddition strategy for the preparation of 3-epi-1-homocasuarine and analogues.

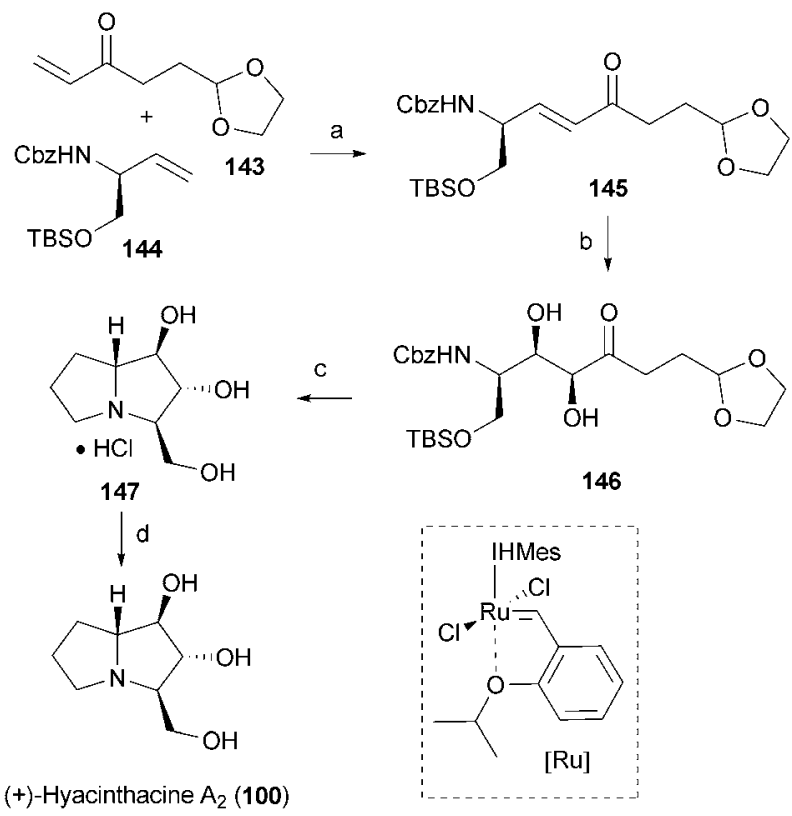

Scheme 23 Blechert's total synthesis of hyacinthacine $\mathrm{A}_{2}$. Reagents and conditions: (a) $[\mathrm{Ru}](10 \mathrm{~mol} \%), \mathrm{CH}_{2} \mathrm{Cl}_{2}$, reflux, $3 \mathrm{~d}, 73 \%$; (b) $\mathrm{AD}$-mix $\beta$, $\mathrm{NaHCO}_{3}, \mathrm{MeSO}_{2} \mathrm{NH}_{2}, \mathrm{~K}_{2} \mathrm{OsO}_{4} \cdot 2 \mathrm{H}_{2} \mathrm{O}, t-\mathrm{BuOH}-\mathrm{H}_{2} \mathrm{O}, 1$ h, $67 \%$; (c) $\mathrm{H}_{2}$ (4 bars), $\mathrm{Pd} / \mathrm{C}\left(10 \mathrm{~mol} \%\right.$ ), $\mathrm{MeOH}, 3$ d; cat. $\mathrm{HCl}$; $\mathrm{H}_{2}$ (4 bars), $3 \mathrm{~d}$; (d) Amberlite IRA, $\mathrm{NH}_{4} \mathrm{OH}, 39 \%$ (4 steps).

molecule (Scheme 24). ${ }^{72}$ In this regard, treatment of nitrone $\mathbf{1 1 6}$ with $\mathrm{SmI}_{2}$ generated an $\alpha$-azanucleophile, ${ }^{73}$ which underwent stereoselective addition to ethyl acrylate to generate $\mathbf{1 4 9}(\mathrm{dr}=$ $9: 1)$. From this intermediate, the synthesis of hyacinthacine $A_{2}$ was completed through $\mathrm{N}-\mathrm{O}$ bond scission, lactamization, lactam reduction and hydrogenolytic cleavage of the benzyl protecting groups. The overall yield of $\mathbf{1 0 0}$ from L-xylose was $19 \%$.

Differing from hyacinthacine $A_{2}$ in the relative configuration at the $\mathrm{C} 1$ stereocenter, hyacinthacine $\mathrm{A}_{1}(\mathbf{1 0 1})$ has proven to be a similarly popular synthetic target (Scheme 25). In this regard, the total synthesis of $\mathbf{1 0 1}$ reported by Landais and Renaud is

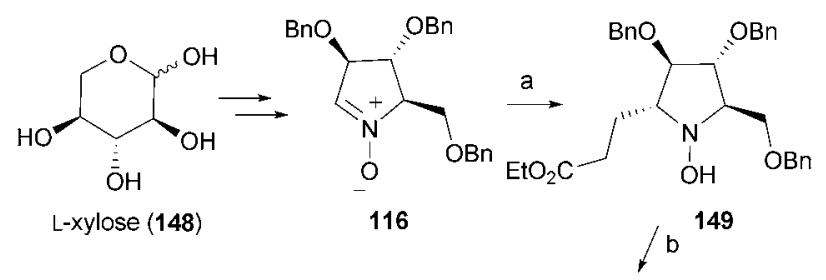

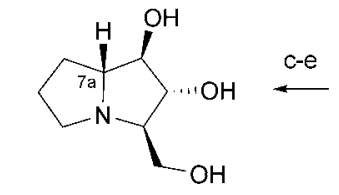

(+)-Hyacinthacine $A_{2}(100)$

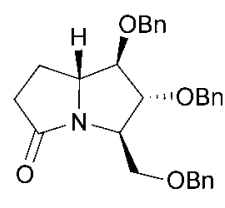

150
Scheme 24 Py's total synthesis of (+)-hyacinthacine $\mathrm{A}_{2}$. Reagents and conditions: (a) ethyl acrylate, $\mathrm{SmI}_{2}, \mathrm{H}_{2} \mathrm{O}$, THF, $-78{ }^{\circ} \mathrm{C}, 3 \mathrm{~h}, 64 \%, \mathrm{dr}=$ 90 : 10; (b) $\mathrm{SmI}_{2}, \mathrm{THF},-78{ }^{\circ} \mathrm{C}$ rt, $24 \mathrm{~h} ; \mathrm{K}_{2} \mathrm{CO}_{3}, \mathrm{EtOH}, \mathrm{H}_{2} \mathrm{O}, 59 \%$ (2 steps), $\mathrm{dr}=90: 10$; (c) $\mathrm{LiAlH}_{4}, \mathrm{THF}, 66^{\circ} \mathrm{C}, 1 \mathrm{~h}, 79 \%$; (d) $\mathrm{H}_{2}, \mathrm{Pd} / \mathrm{C}$, $\mathrm{MeOH}, \mathrm{THF}, 6 \mathrm{M} \mathrm{HCl}$, rt, 4 d; (e) Dowex 1X8, 79\% (2 steps). 


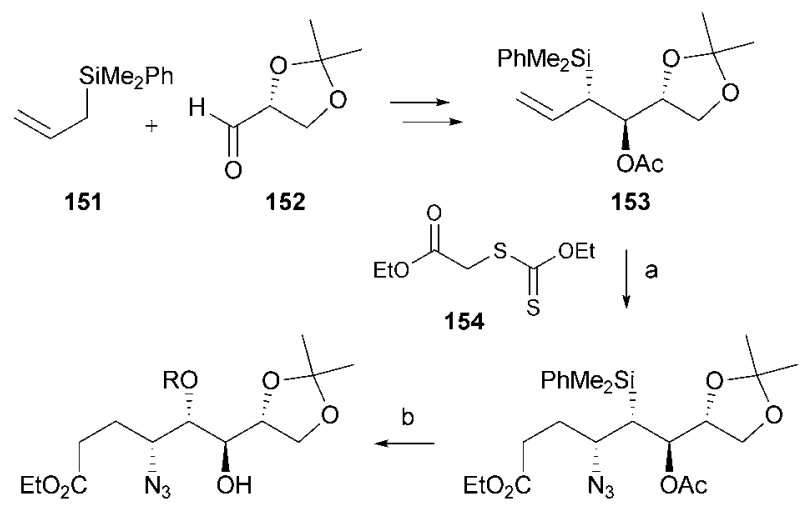

$156 a(R=H)+156 b(R=O A c)$

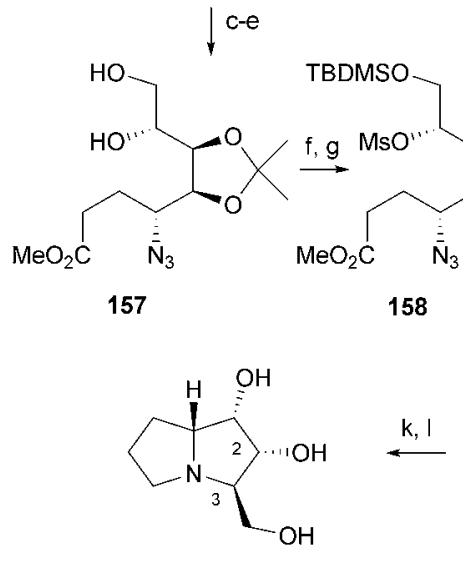

(+)-Hyacinthacine $A_{1}(101)$
155
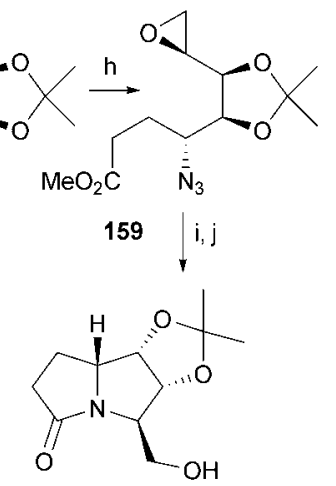

160
Scheme 25 Renaud's total synthesis of (+)-hyacinthacine $\mathrm{A}_{1}$. Reagents and conditions: (a) 154, $\left(\mathrm{Bu}_{3} \mathrm{Sn}\right)_{2}, t-\mathrm{BuON}=\mathrm{NO} t-\mathrm{Bu}$, benzene, $\operatorname{pyrSO}_{2} \mathrm{~N}_{3}$, $60{ }^{\circ} \mathrm{C}, 84 \%$, (synlanti 85 : 15); (b) $\mathrm{AcOOH}, \mathrm{AcOH}, \mathrm{KBr}, \mathrm{AcONa}, 0{ }^{\circ} \mathrm{C} \rightarrow$ rt, $84 \%$; (c) Dowex 1X10, $\mathrm{MeOH}$, rt; (d) $\mathrm{Me}_{2} \mathrm{C}(\mathrm{OMe})_{2}, p-\mathrm{TsOH}, \mathrm{CH}_{2} \mathrm{Cl}_{2}$, rt, $12 \mathrm{~h}$; (d) $\mathrm{Zn}\left(\mathrm{NO}_{3}\right)_{2} \cdot 6 \mathrm{H}_{2} \mathrm{O}, \mathrm{CH}_{3} \mathrm{CN}, 50{ }^{\circ} \mathrm{C}, 6 \mathrm{~h}, 55 \%$ (3 steps); (f) $\mathrm{TBSCl}$, pyridine, rt, $5 \mathrm{~h}$; (g) $\mathrm{MsCl}$, pyridine, rt, $3 \mathrm{~h}, 84 \%$ (2 steps); (h) TBAF, THF, rt, $2 \mathrm{~h}$; then $\mathrm{K}_{2} \mathrm{CO}_{3}, \mathrm{MeOH}, \mathrm{rt}, 12 \mathrm{~h}, 70 \%$; (i) $\mathrm{H}_{2}, \mathrm{Pd} / \mathrm{C}$, $\mathrm{MeOH}, \mathrm{rt}, 2 \mathrm{~h}$; (j) $\mathrm{Et}_{3} \mathrm{~N}, \mathrm{MeOH}$, reflux; (k) $\mathrm{LiAlH}_{4}$, THF, reflux, $1 \mathrm{~h}$; (l) $\mathrm{HCl}, \mathrm{MeOH}$ then Dowex $1 \mathrm{X} 10\left(\mathrm{OH}^{-}\right.$form $), 65 \%$ (2 steps).

notable not only for being the first but also for its reliance upon the diastereoselective, radical carboazidation reaction of allylsilane 153 to establish the $\mathrm{C} 2 / 3$ stereodiad. ${ }^{74}$ Having served its purpose, to effect 1,2-stereocontrol, the $\mathrm{PhMe}_{2} \mathrm{Si}$ group was now removed via Tamao-Fleming oxidation to generate 156a and 156b, which through saponification and deacetalization were converted to 157. A number of protecting group manipulation steps then led to epoxide 159, which upon hydrogenation and treatment with base, underwent 5-exo-tet cyclization to generate pyrrolizidinone 160. Reduction of the lactam with $\mathrm{LiAlH}_{4}$ and deacetalization then provided hyacinthacine $A_{1}$ (101) in 13 steps and $8 \%$ overall yield.

Published shortly after the Landais and Renaud report, Donohoe's flexible synthesis of $( \pm)$-hyacinthacine $A_{1}$ (101) and related targets centers around the stereodivergent generation and functionalization of 3-pyrrolines (Scheme 26). ${ }^{75}$ In the case of 101, partial Birch reduction of pyrrole 161 in ammonia generated trans-162. Poli dihydroxylation $\left(\mathrm{OsO}_{4}, \mathrm{Me}_{3} \mathrm{NO}\right)$, diol protection

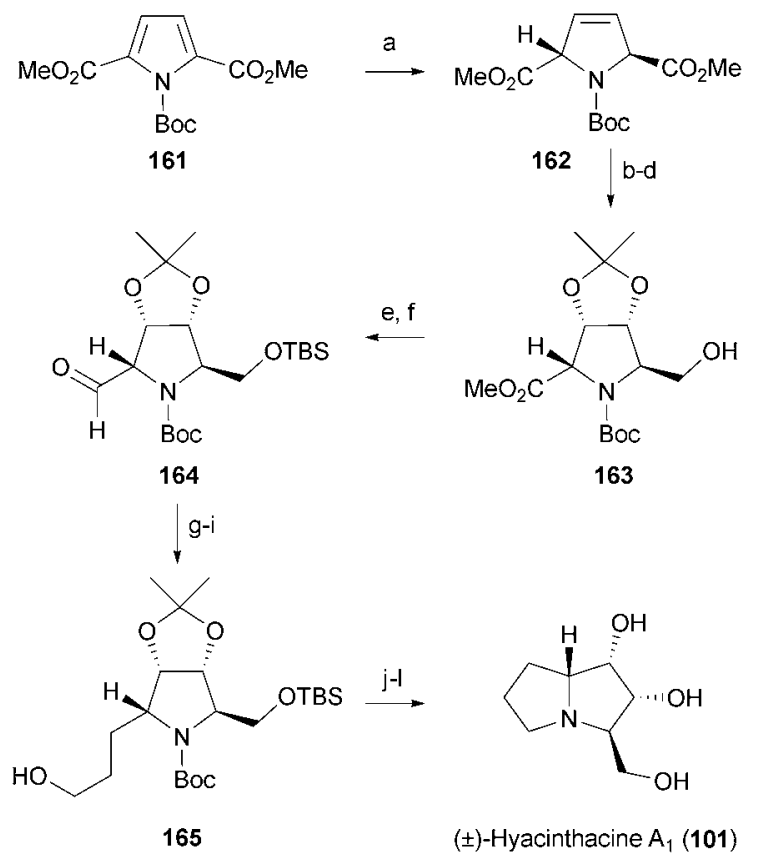

Scheme 26 Donohoe's total synthesis of $( \pm)$-hyacinthacine $\mathrm{A}_{1}$. Reagents and conditions: (a) $\mathrm{Li}, \mathrm{NH}_{3},-78{ }^{\circ} \mathrm{C}$, isoprene, $\mathrm{NH}_{4} \mathrm{Cl}, 73 \%$; (b) cat. $\mathrm{OsO}_{4}$, $\mathrm{CH}_{2} \mathrm{Cl}_{2}, \mathrm{Me}_{3} \mathrm{NO}$, 95\%; (c) dimethoxypropane, $p$ - $\mathrm{TsOH}$, acetone, 94\%; (d) $\mathrm{NaBH}_{4}, \mathrm{MeOH}-\mathrm{THF}$; (e) TBSCl, imidazole, DMF, $85 \%$ (2 steps); (f) DIBAL- $\mathrm{H}, \mathrm{CH}_{2} \mathrm{Cl}_{2},-40{ }^{\circ} \mathrm{C}, 97 \%$; (g) $\mathrm{Ph}_{3} \mathrm{P}=\mathrm{CHCO}_{2} \mathrm{Me}$, toluene, $110^{\circ} \mathrm{C}$, $100 \%$; (h) $\mathrm{H}_{2}, \mathrm{Pt}_{2} \mathrm{O}, \mathrm{MeOH}, \mathrm{rt}, 100 \%$; (i) DIBAL-H, $\mathrm{CH}_{2} \mathrm{Cl}_{2},-78^{\circ} \mathrm{C} \rightarrow \mathrm{rt}$, $93 \%$; (j) $\mathrm{MsCl}$, pyridine, $0{ }^{\circ} \mathrm{C}$; (j) TESOTf, 2,6-lutidine, $\mathrm{CH}_{2} \mathrm{Cl}_{2},-78^{\circ} \mathrm{C} \rightarrow$ rt, $91 \%$ (2 steps); (k) $(\mathrm{COCl})_{2}, \mathrm{MeOH}, \mathrm{rt}, 89 \%$.

and reduction of the more accessible ester group yielded $\mathbf{1 6 3}$ which, by way of a 3-step sequence, was homologated to compound 165. Activation of this primary alcohol via methanesulfonylation and removal of the $N$-Boc group then triggered ring closure to form the pyrrolizidine ring. Finally, global deprotection using $\mathrm{HCl}$ in $\mathrm{MeOH}$ generated racemic hyacinthacine $A_{1}$ (101) in high yield. Donhoe has subsequently extended this chemistry to the enantioselective preparation of a number of other pyrrolizidine natural products, including 2,3,7-tri-epi-australine and (+)-hyacinthacines $\mathrm{A}_{6}$ and $\mathrm{A}_{7}$, as well as (+)-hyacinthacine $A_{1}$ itself. $^{76}$

In common with the work of Landais and Renaud, Delair's synthesis of hyacinthacine $A_{1}$ (101) also employs a dimethylphenylsilyl substituent as an agent of stereocontrol and a surrogate hydroxyl group (Scheme 27). ${ }^{77}$ The central theme of this work is the establishment of the $\mathrm{C} 7 \mathrm{a}$ stereocenter through an enantioselective dichloroketene-enol ether $[2+2]$ cycloaddition which was used to access 167 (vide infra) ${ }^{78}$ From this point, introduction of the $\mathrm{C} 3$ stereocenter was accomplished by $N$-protection, lactam reduction and reaction of 168 with magnesio(dimethylphenylsilylmethyl)cuprate. After generating pyrrolizidine 171, removal of the chiral auxiliary and dehydration generated 172. A sequence of dihydroxylation and TamaoFleming oxidation now generated triol 173, which was reduced with borane to provide (+)-hyacinthacine $\mathrm{A}_{1}$ (101).

Chandrasekhar's enantioselective synthesis of hyacinthacine $\mathrm{A}_{1}(\mathbf{1 0 1})^{79}$ is notable both for its use of a stereoretentive, Pdcatalysed epoxide ring-opening reaction and the generation of 

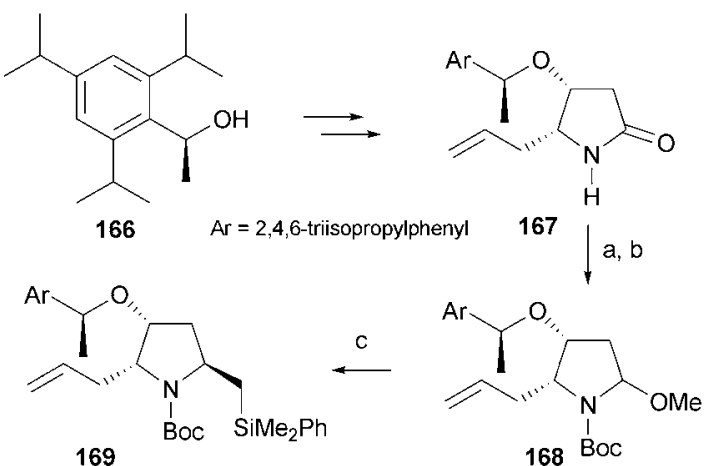

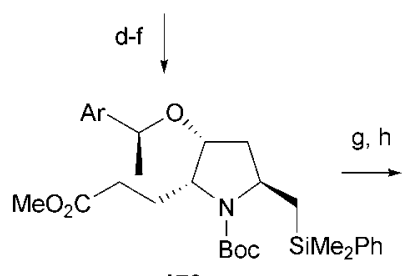

170

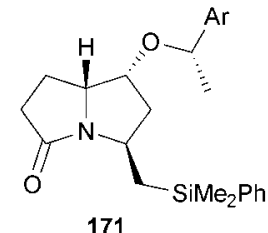

171

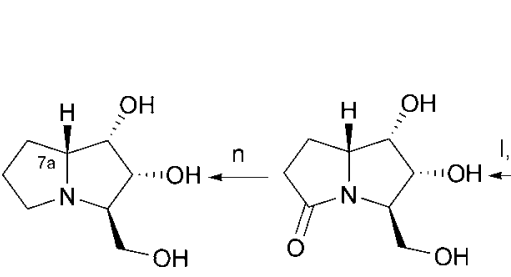

173

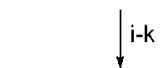

(+)-Hyacinthacine $A_{1}(101)$

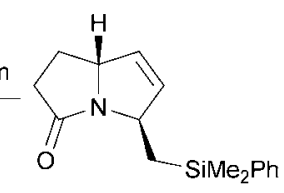

172
Scheme 27 Delair's total synthesis of (+)-hyacinthacine $\mathrm{A}_{1}$. Reagents and conditions: (a) $\mathrm{Boc}_{2} \mathrm{O}, \mathrm{DMAP}_{2} \mathrm{Et}_{3} \mathrm{~N}, 85 \%$; (b) $\mathrm{LiEt}_{3} \mathrm{BH}$; then p-TsOH, $\mathrm{MeOH}, 84 \%$; (c) $\mathrm{PhMe}_{2} \mathrm{SiCH}_{2} \mathrm{MgCl}, \mathrm{CuBr} \cdot \mathrm{SMe}_{2}, \mathrm{BF}_{3} \cdot \mathrm{OEt}_{2}$, $96 \%, \mathrm{dr}=6: 1$; (d) $\mathrm{Sia}_{2} \mathrm{BH} ; \mathrm{H}_{2} \mathrm{O}_{2}$; (e) Dess-Martin periodinane, $\mathrm{CH}_{2} \mathrm{Cl}_{2}$; (f) $\mathrm{NaClO}_{2}, \mathrm{CH}_{2} \mathrm{~N}_{2}, 67 \%$ (3 steps); (g) TMSOTf; (h) toluene, heat, $63 \%$ (2 steps); (i) TFA, 87\%; (j) KH, $\mathrm{CS}_{2}$, MeI, (k) heat, 72\% (2 steps); (l) cat. $\mathrm{OsO}_{4}, \mathrm{NMO}$, acetone, 99\%; (m) $\mathrm{HBF}_{4} \cdot \mathrm{OMe}_{2}, \mathrm{KF} ; m$-CPBA, $82 \%$; (n) $\mathrm{BH}_{3} \cdot \mathrm{SMe}_{2}, 78 \%$.

the pyrrolizidine ring system in a five-step, one-pot "domino" hydrogenation (Scheme 28). Commencing from compound 175, this (+)-diethyl tartrate derivative was converted in six steps and high overall yield to 177 . Treatment of this $\gamma, \delta$-epoxyester with $\mathrm{TMSN}_{3}$ in the presence of catalytic $\mathrm{Pd}\left(\mathrm{PPh}_{3}\right)_{4}$ now mediated ring opening with double inversion of configuration at the $\gamma$ position to yield syn azido alcohol $\mathbf{1 7 8} .^{\mathbf{8 0}}$ After protecting of the alcohol as a MOM ether, the acetonide group of $\mathbf{1 7 9}$ was hydrolyzed and the primary hydroxyl group selectively silylated to provide $\mathbf{1 8 0}$. To accomplish pyrrolizidinone formation, $\mathbf{1 8 0}$ was converted to the corresponding mesylate and this material hydrogenated over $\mathrm{Pd} / \mathrm{C}$ to yield 181. Removal of the $O$-protecting groups and lactam reduction using $\mathrm{LiAlH}_{4}$ then provided (+)-hyacinthacine $\mathrm{A}_{1}$ (101) in 14 steps and 8.5\% overall yield from $\mathbf{1 7 5}$.

Isolated from the leguminous plant Alexa leiopetala by Asano and co-workers, ${ }^{\mathbf{8 1}}(+)$-alexine $(\mathbf{1 0 2})$ is a potent glycosidase inhibitor and also the first pyrrolizidine alkaloid to be found with a C3 carbon substituent. Despite its biological activity, alexine has, until recently, proven to be a less popular synthetic target than other members of the pyrrolizidine family. Notably therefore, Yoda and co-workers have developed a unified, carbohydrate-based approach to (+)-alexine (102) and its C7 epimer, which in common with Py's hyacinthacine $\mathrm{A}_{2}$ synthesis, employs L-xylose as its source of asymmetry (Scheme 29). This synthesis commences from 2,3,5-tri- $O$-benzyl-L-xylose (182), which after conversion to the corresponding furanosylamine underwent vinyl addition to furnish $\mathbf{1 8 3}$ as a single diastereomer. A series of protecting group manipulations then provided alkene 184, which was cleaved via Lemieux-Johnson oxidation to the corresponding aldehyde. A second substrate-controlled (Cram) vinyl addition then established the final stereocenter, albeit with the undesired stereochemistry. Inversion of the hydroxyl-bearing stereocenter in $\mathbf{1 8 5}$ was achieved through a cycle of TPAP oxidation and chelation-controlled Luche reduction. From 186, the remainder of the synthesis involved a series of protecting group manipulations, to enable the formation of pyrrolidine $\mathbf{1 8 7}$, and $N$-alkylative ring closure of this intermediate to generate alexine (102). As the synthesis of (-)-7-epi-alexine did not require stereoinversion at $\mathbf{1 8 5}$, Yoda's route to this compound involved two fewer steps than that to alexine.

Of the pyrrolizidine syntheses reported during the period under review, Somfai's non-carbohydrate-based approach to (+)-alexine (102), is of particular note for the rapidity and stereoselectivity with which the tetrasubstituted pyrrolidine subunit of the target is established (Scheme 30).$^{82}$ The key transformation of this synthesis is in fact the first and involves the diastereoselective, Lewis-acid-promoted $[3+2]$ annulation of $N$-Ts- $\alpha$-aminoaldehyde 189 and 1,2-bis(silyl)propene 190. Having established 4 of 5 stereocenters in the target molecule, conversion of 191 to aldehyde 192 now set the stage for introduction of the final chiral center, which was accomplished via Sakurai-Hosomi allylation in the presence of $\mathrm{TiCl}_{4}$. After bis- $O$-benzylation of the resulting diol, sequential Lemieux-Johnson oxidation and in situ reduction generated 194 efficiently. Reductive cleavage of the sulfonamide protecting group was followed by a sequence of Appel cyclization $^{83}$ and Tamao-Fleming oxidation to yield pyrrolizidine 196a together with its $N$-oxide 196b. Hydrolysis of 196a and subsequent hydrogenolysis with 196b furnished (+)-alexine (102).

\subsection{Indolizidines}

Isolated from the seeds of the Moreton Bay chestnut tree (Castanospermum australe), ${ }^{84}$ the indolizidine alkaloid (+)-castanospermine (205) displays an impressive range of biological activities which stem from its potent inhibition of endoplasmic reticulum $\alpha$-glucosidase I as well as glucosidase II, and intestinal maltase and sucrase. ${ }^{85}$ Importantly, castanospermine exhibits activity against a range of human viral pathogens, including parainfluenza, dengue virus, HSV-2 and HIV-1. ${ }^{86}$ Adding further impetus to the development of synthetic routes to $\mathbf{2 0 5}$, castanospermine has most recently been found to inhibit the Rho/Rasglycosylating action of Clostridium difficile toxin $\mathrm{B},{ }^{87}$ the major virulence factor of this bacteria and the causative agent of antibiotic-associated pseudomembranous colitis. ${ }^{\mathbf{8 8}}$

In view of the biological activity associated with 205, it is understandable that this alkaloid and its derivatives remain popular synthetic targets. ${ }^{89}$ The self-evident stereochemical relationship between $(+)$-castanospermine (205) and D-glucose (197), which share four stereocenters, have made this carbohydrate a popular starting point for the preparation of 205. In this regard, Murphy and Cronin have reported the total synthesis of 

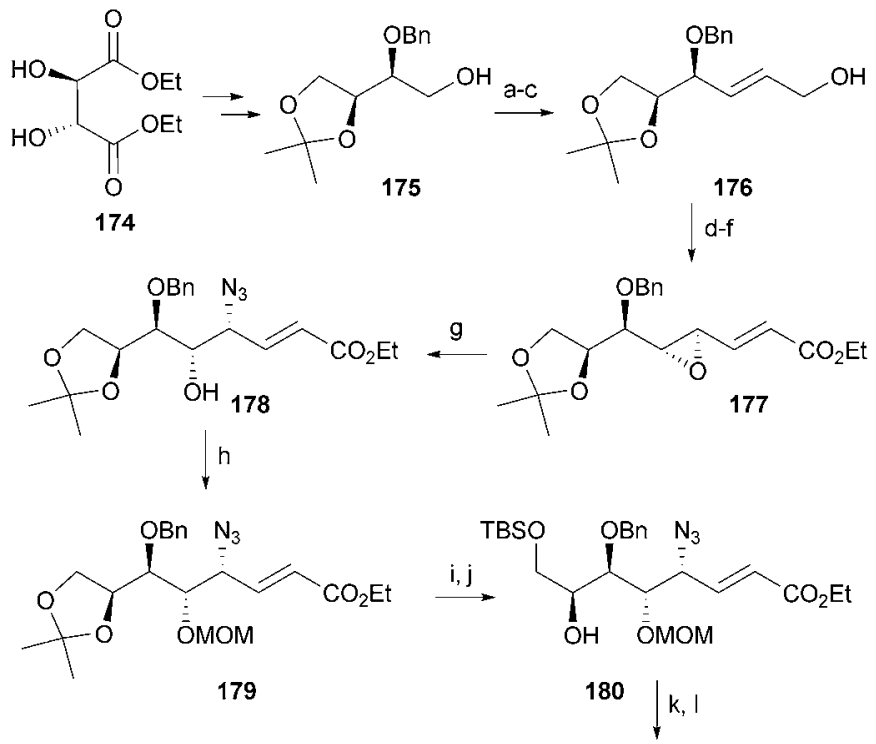

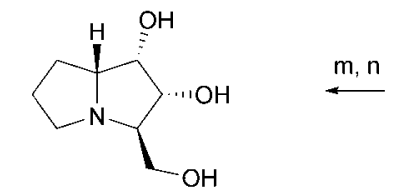

(+)-Hyacinthacine $A_{1}(101)$

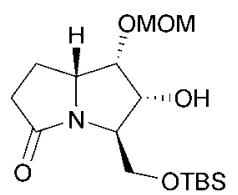

181

Scheme 28 Chandrasekhar's total synthesis of (+)-hyacinthacine $\mathrm{A}_{1}$. Reagents and conditions: (a) IBX, EtOAc, reflux, $3 \mathrm{~h} ;(\mathrm{b}) \mathrm{Ph}_{3} \mathrm{P}=\mathrm{CHCO}_{2} \mathrm{Et}$, $\mathrm{CH}_{2} \mathrm{Cl}_{2}, 0{ }^{\circ} \mathrm{C} \rightarrow \mathrm{rt}, 30 \mathrm{~min}, 90 \%$ (2 steps); (c) DIBAL-H, THF, $-10 \rightarrow 0{ }^{\circ} \mathrm{C}, 1 \mathrm{~h}, 96 \%$; (d) (-)-DET, Ti(O-i-Pr) $4, \mathrm{TBHP}, \mathrm{CH}_{2} \mathrm{Cl}{ }_{2},-23{ }^{\circ} \mathrm{C}, 10 \mathrm{~h}, 93 \%, \mathrm{dr}$ $>98 \%$; (e) IBX, EtOAc, reflux, $3 \mathrm{~h}$; (f) $\mathrm{Ph}_{3} \mathrm{P}=\mathrm{CHCO}_{2} \mathrm{Et}$, benzene, $0{ }^{\circ} \mathrm{C} \rightarrow \mathrm{rt}, 10 \mathrm{~min}, 90 \%$ (2 steps); (g) TMSN $, \mathrm{Pd}(\mathrm{PPh})_{4}(10 \mathrm{~mol} \%), \mathrm{THF}, 12 \mathrm{~h}, \mathrm{rt}$; (h) MOMCl, DIPEA, $\mathrm{CH}_{2} \mathrm{Cl}_{2}, \mathrm{rt}, 48 \mathrm{~h}, 77 \%$; (i) PPTS, $\mathrm{MeOH}, \mathrm{rt}, 24 \mathrm{~h}, 74 \%$; (j) TBSCl, imidazole, $\mathrm{CH}_{2} \mathrm{Cl}_{2}, \mathrm{rt}, 30 \mathrm{~min}, 78 \%$; (k) $\mathrm{MsCl}_{2} \mathrm{Et}_{3} \mathrm{~N}, \mathrm{CH}_{2} \mathrm{Cl}_{2},-10{ }^{\circ} \mathrm{C}, 10$ min, 88\%; (l) $\mathrm{H}_{2}, \mathrm{Pd} / \mathrm{C}$, EtOH, rt, 12 h; then $\mathrm{K}_{2} \mathrm{CO}_{3}$, EtOH, $\mathrm{H}_{2} \mathrm{O}$, reflux, $2 \mathrm{~h}, 65 \%$; (m) PTSA, MeOH, rt, 12 h; (n) LiAlH $\mathrm{H}_{4}$, THF, reflux, 2 h, $58 \%$ (2 steps).

(+)-castanospermine (205) and 1-epi-castanospermine (206) from 6-deoxyhex-5-enopyranosyl azide 198 (Scheme 31). ${ }^{90}$ Since this substrate houses all but one of the stereocenters present in the piperidine ring of $\mathbf{2 0 5}$, the initial stages of the synthesis focused upon a) introduction of the $\mathrm{C} 5$ methoxy group required for the antepenultimate reductive amination cascade and b) two-carbon homologation. The former task was accomplished through formation and ring opening of spiroepoxide 199 to primary alcohol 200, while homologation was completed by aldol condensation of aldehyde 201. Unfortunately, both processes displayed marginal diastereoselectivity and offered access to intermediate 202b in very low overall yield. Nonetheless, the rapidity with which castanospermine was subsequently accessed is worthy of note: high-pressure hydrogenation of 202b under acidic conditions provided indolizidine $\mathbf{2 0 3}$ as a single isomer! After temporary silylation of the free hydroxyl groups, reduction with $\mathrm{LiAlH}_{4}$ generated (+)-castanospermine (205). (+)-1-epiCastanospermine (206) was prepared in similar fashion, albeit in higher overall yield, from compound 204.

Also employing D-glucose as the starting point of their 2009 synthesis of (+)-castanospermine (205), Madsen and co-workers exploit the transannular cyclization of an nine-membered amino epoxide to generate the indolizidine core of this alkaloid (Scheme 32). ${ }^{91}$ After conversion of $\alpha$-D-glucopyranoside (207) to 6iodopyranoside 208, zinc-mediated fragmentation provided unsaturated aldehyde 209, which was subjected to reductive amination with homoallylamine using $\mathrm{NaCNBH}_{3}$ and then $\mathrm{N}$ acylated to yield 210. Cyclization of this 1,10-diene now proceeded at high dilution in the presence of the Hoveyda-Blechert ruthenium catalyst to provide azonine 211a together with azocine $\mathbf{2 1 1 b}$. This byproduct likely arises as a result of $\mathrm{Ru}$-mediated alkene isomerisation and subsequent elimination of propene during metathesis. ${ }^{92}$ After diastereoselective alkene epoxidation, transannular cyclization was triggered through treatment with $\mathrm{KO}-t-\mathrm{Bu}$ and proceeded to furnish strained azetidine 212a and indolizidine $\mathbf{2 1 2} \mathbf{b}$. Hydrogenolysis of the latter product provided (+)-castanospermine (205) in 9 steps and $27 \%$ overall yield from 197. Although prior to the timeframe of this review, the RCMtransannular epoxide ring opening approach to bicyclic alkaloids was first reported by White and co-workers, who employed this strategy in the synthesis of $(+)$-australine..$^{93}$

While a significant proportion of castanospermine syntheses rely on reductive amination to establish one or both of the $\mathrm{C}-\mathrm{N}$ bonds within this target, Dhavale's approach to $\mathbf{2 0 5}$ is notable in that it employs an 5-endo alkene aminomercuration to accomplish this task while simultaneously creating the pyrrolidine ring (Scheme 33). ${ }^{94}$ From D-glucose-derived nitrone 213, diastereoselective 1,3-addition of vinylmagnesium bromide preferentially generated D-gluco- $N$-allylamine $\mathbf{2 1 4 b}$, which after separation, was converted to 216. Although vinyl addition to this aldehyde proceeded with acceptable diastereoselectivity $(\mathrm{dr}=3: 1)$, the major product of this reaction proved to bear the undesired $5 R, 6 R$ 

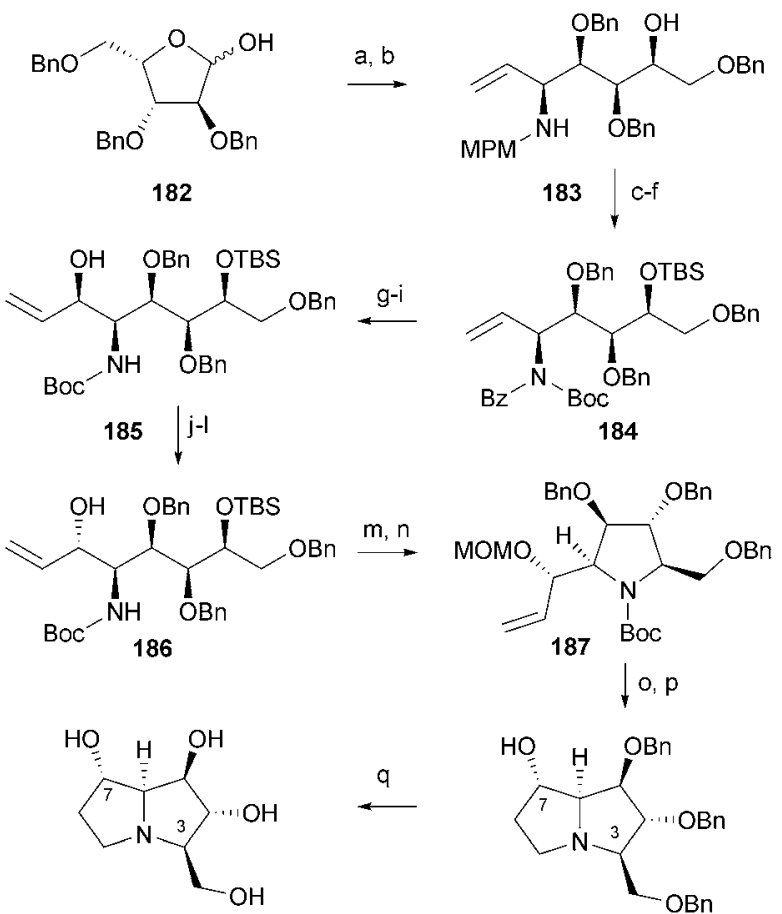

(+)-Alexine (102)

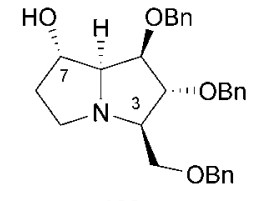

189

Scheme 29 Yoda's total synthesis of $(+)$-alexine. Reagents and conditions: (a) $\mathrm{MPMNH}_{2}, 4 \AA \mathrm{MS}, \mathrm{PhCH}_{3}$, reflux; (b) vinylmagnesium chloride, THF, $-78 \rightarrow 0{ }^{\circ} \mathrm{C}, 2 \mathrm{~h}, 75 \%$ (2 steps); (c) $\mathrm{BzCl}, \mathrm{CH}_{2} \mathrm{Cl}_{2}, \mathrm{rt}, 3 \mathrm{~h}, 89 \%$; (d) $\mathrm{CAN}, \mathrm{MeOH}, 0{ }^{\circ} \mathrm{C} \rightarrow \mathrm{rt}, 4 \mathrm{~h}, 86 \%$; (e) TBSCl, imidazole, DMF, rt, 12 h, $89 \%$; (f) (Boc) ${ }_{2} \mathrm{O}, \mathrm{Et}_{3} \mathrm{~N}$, DMAP, $\mathrm{CH}_{2} \mathrm{Cl}_{2}, \mathrm{rt}, 12 \mathrm{~h}, 92 \%$; (g) $\left(\mathrm{Me}_{2} \mathrm{~N}\right)_{2} \mathrm{C}=\mathrm{NH}_{2}, 130^{\circ} \mathrm{C}, 8 \mathrm{~h}, 98 \%$; (h) $\mathrm{OsO}_{4}, \mathrm{NMO}$, acetone, $12 \mathrm{~h}, 94 \%$; (i) $\mathrm{NaIO}_{4}, \mathrm{THF}-\mathrm{H}_{2} \mathrm{O}(1: 1), 4 \mathrm{~h}$; then vinylmagnesium chloride, THF, $-78{ }^{\circ} \mathrm{C}, 95 \%$ (2 steps); (j) TPAP, NMO, $4 \AA \mathrm{MS}, \mathrm{CH}_{2} \mathrm{Cl}_{2}, \mathrm{rt}, 12 \mathrm{~h}, 92 \%$; (k) $\mathrm{NaBH}_{4}, \mathrm{CeCl}_{3} \cdot \mathrm{H}_{2} \mathrm{O}, \mathrm{MeOH},-45{ }^{\circ} \mathrm{C}, 2 \mathrm{~h}, 80 \%$; (l) $\mathrm{MOMCl}$, $i$ - $\mathrm{Pr}_{2} \mathrm{NEt}_{2}, 12 \mathrm{~h}, 96 \%$; (m) $\mathrm{Bu}_{4} \mathrm{NF}, \mathrm{THF}, 3 \mathrm{~h}, 91 \%$; (n) $\mathrm{MsCl}, \mathrm{Et}_{3} \mathrm{~N}$, $\mathrm{CH}_{2} \mathrm{Cl}_{2}, \mathrm{rt}, 12 \mathrm{~h}$; then $t$-BuOK, THF, rt, $12 \mathrm{~h}, 87 \%$ (2 steps); (o) 9-BBN, $30 \% \mathrm{H}_{2} \mathrm{O}_{2}, 3 \mathrm{M} \mathrm{NaOH}$, THF, $97 \%$; (p) $\mathrm{MsCl}, \mathrm{Et}_{3} \mathrm{~N}, \mathrm{CH}_{2} \mathrm{Cl}_{2}$; then $\mathrm{BF}_{3} \cdot \mathrm{OEt}_{2}, \mathrm{CH}_{2} \mathrm{Cl}_{2},-20{ }^{\circ} \mathrm{C}, 84 \%$ (2 steps); (q) $\mathrm{Pd} / \mathrm{C}$ (10 $\mathrm{mol} \%$ ), $\mathrm{HCO}_{2} \mathrm{NH}_{4}, \mathrm{MeOH}$, reflux, $2 \mathrm{~h}, 83 \%$.

configuration. Facial selectivity in this case was rationalized in terms of the Felkin-Anh transition state model. Moving forward from 217a, hydrolysis of the oxazolidinone ring now yielded the $\beta$-hydroxy- $\gamma$-alkenylamine, which upon treatment with mercury(II) acetate underwent 5-endo-trig-aminomercuration to form pyrrolidine 218, after in situ reduction with $\mathrm{NaBH}_{4}$. Correction of the $\mathrm{C} 1$ (castanospermine) stereocenter was now brought about by formation and reduction of ketone 219, which generated 220 with high diastereoselectivity. Finally, a sequence of acetonide deprotection and hydrogenation generated the indolizidine ring and provided castanospermine (205). Dhavale has subsequently adapted this synthetic strategy to the preparation of two new $\mathrm{Cl}$ epimeric hydroxymethyl castanospermine congeners that display potent immunodulatory activity. ${ }^{95}$

In an extension of their work on the application of the Petasis borono-Mannich reaction ${ }^{96}$ to the preparation of alkaloids, ${ }^{97}$ Pyne and co-workers have reported the use of this remarkable transformation in an 11-step step of (+)-castanospermine (205) (Scheme 34). ${ }^{98}$ In this regard, three-component condensation of L-xylose, allylamine and an (E)-vinyl boronic acid proceeded

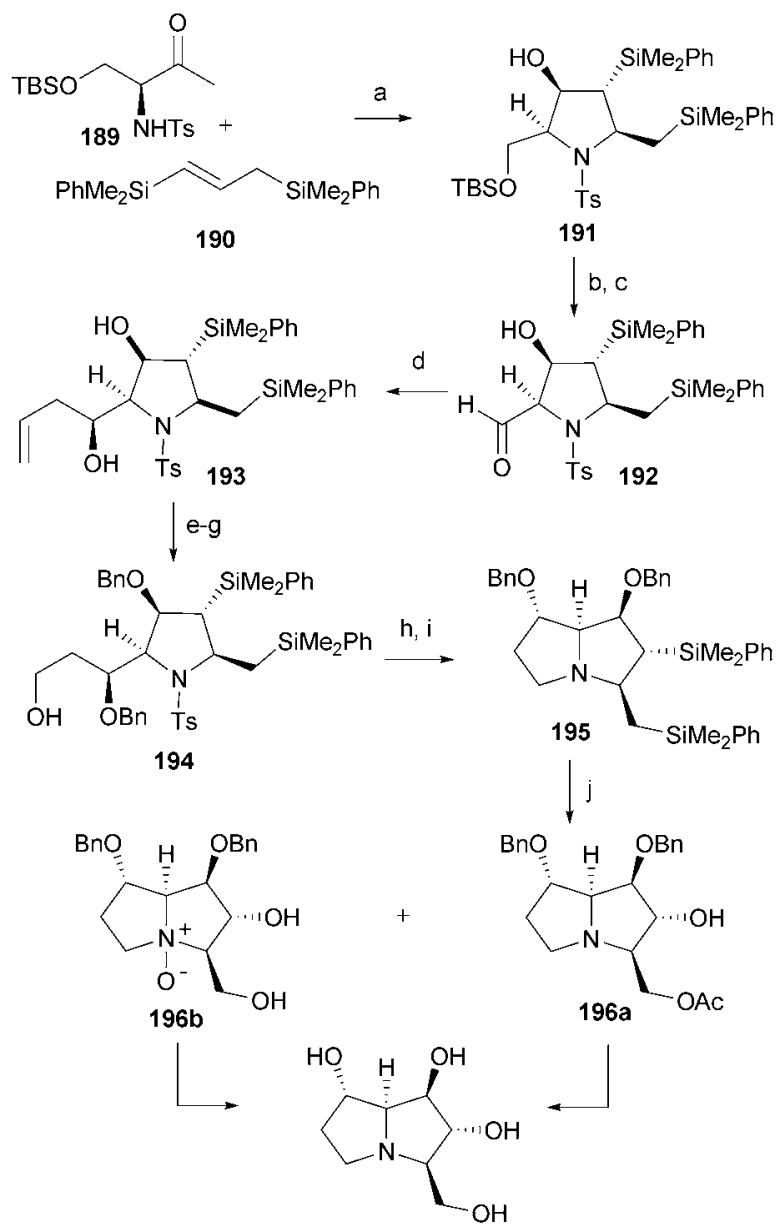

(+)-Alexine (102)

Scheme 30 Somfai's total synthesis of (+)-alexine. Reagents and conditions: (a) $\mathrm{MeAlCl}_{2}, \mathrm{CH}_{2} \mathrm{Cl}_{2},-78{ }^{\circ} \mathrm{C}, 57 \%$, dr > 40 : 1; (b) $\mathrm{AcOH}$, THF, $\mathrm{H}_{2} \mathrm{O}, 96 \%$; (c) TEMPO, $\mathrm{NaOCl}, \mathrm{KBr}, \mathrm{CH}_{2} \mathrm{Cl}_{2}-\mathrm{H}_{2} \mathrm{O}, 99 \%$; (d) allyltrimethylsilane, $\mathrm{TiCl}_{4},-78{ }^{\circ} \mathrm{C}, 70 \%$, dr > 95 : 5; (e) $\mathrm{BnBr}, \mathrm{KHMDS}$, THF, $-78{ }^{\circ} \mathrm{C}, 85 \%$; (f) $\mathrm{OsO}_{4}, \mathrm{NaIO}_{4}$, pyridine, $\mathrm{CH}_{3} \mathrm{CN}-\mathrm{H}_{2} \mathrm{O}$; (g) $\mathrm{NaBH}_{4}, 0{ }^{\circ} \mathrm{C}, \mathrm{MeOH}, 72 \%$; (h) $\mathrm{Na}^{+} \mathrm{C}_{10} \mathrm{H}_{8}{ }^{-}$, DME, $-60{ }^{\circ} \mathrm{C}, 99 \%$; (i) $\mathrm{CBr}_{4}, \mathrm{Ph}_{3} \mathrm{P}, \mathrm{Et}_{3} \mathrm{~N}, \mathrm{CH}_{2} \mathrm{Cl}_{2}, 64 \%$; (j) $\mathrm{Hg}(\mathrm{OTf})_{2}, \mathrm{AcO}_{2} \mathrm{H}, \mathrm{AcOH}, 196 \mathbf{a}$ (41\%), 196b (21\%), (k) LiOH, THF, $\mathrm{H}_{2} \mathrm{O}, 90 \%$; (l) $\mathrm{H}_{2}, \mathrm{Pd} / \mathrm{C}, \mathrm{EtOH}, 70 \%$.

with complete diastereocontrol to yield 221. ${ }^{99}$ The 1,2,3-triol remaining after chemoselective formation of oxazolidinone $\mathbf{2 2 2}$ was differentially alkylated to provide compound $\mathbf{2 2 3 b}$, whose formation was accompanied by significant quantities of oxazinone 223a, the product of acyl migration. RCM of this mixture using Grubbs' second-generation catalyst and separation of the resulting 3-pyrroline products gave $\mathbf{2 2 4}$ in 38\% overall yield from the 1,6-diene. syn-Dihydroxylation of this cyclic alkene now proceeded from the endo face, under stereoelectronic control, ${ }^{100}$ to generate the corresponding 1,2-diol from which the extraneous C2 (castanospermine) hydroxyl group was removed through formation and regioselective reduction $\left(\mathrm{NaBH}_{4}, \mathrm{DMA}\right)$ of cyclic sulfate 225. After solvolysis of the trityl group, oxazolidinone 226 was saponified to form 227a, a process which unexpectedly gave rise to furan $\mathbf{2 2 7}$ b. Notwithstanding the routine appearance of this penultimate transformation, cyclization of 227a to generate the indolizidine ring system was found to 


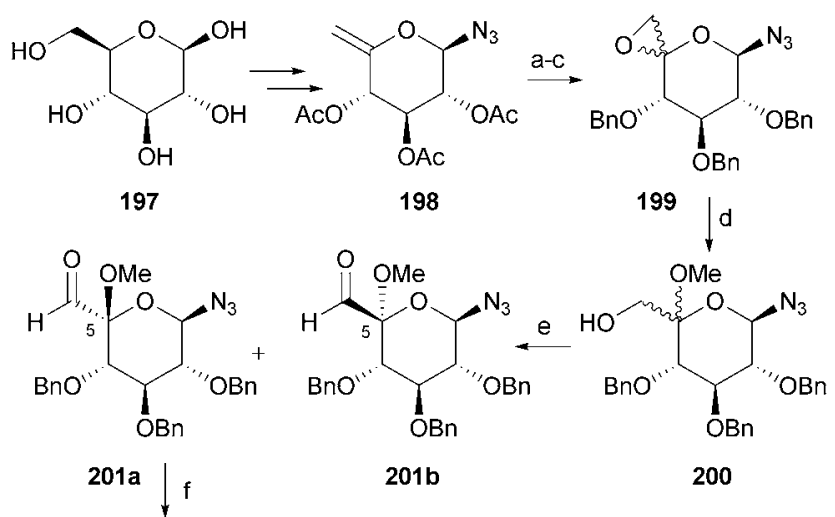

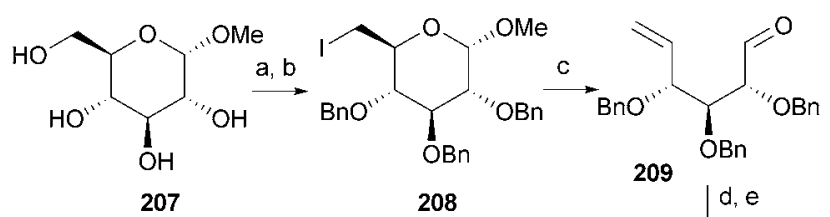

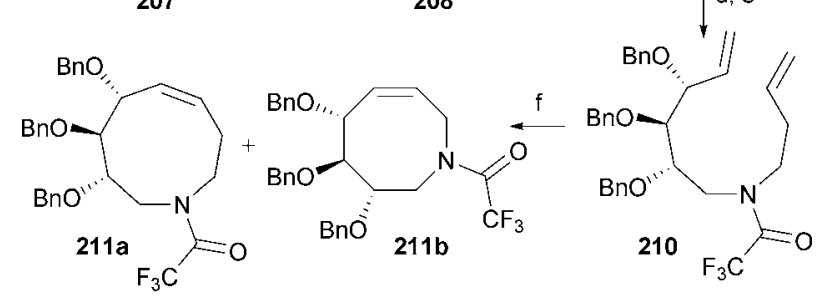<smiles>CCOC(=O)C[C@@H](O)[C@@]1(O)O[C@H](N)[C@@H](OCc2ccccc2)[C@H](OCc2ccccc2)[C@H]1Cc1ccccc1</smiles><smiles>CCOC(=O)C[C@H](O)[C@@]1(OC)OC([NH3+])[C@@H](Cc2ccccc2)[C@H](Br)[C@H]1OCc1ccccc1</smiles><smiles>O=C(O)C1CN2CC[C@H]2[C@H](O)[C@@H](OCc2ccccc2)[C@@H]1OCc1ccccc1</smiles>

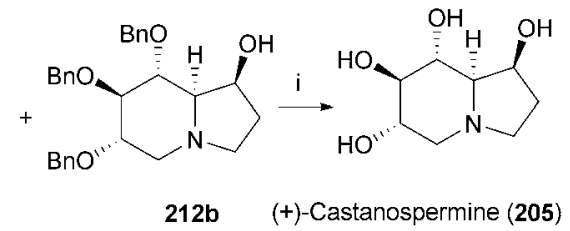

Scheme 32 Madsen's total synthesis of (+)-castanospermine. Reagents and conditions: (a) $\mathrm{I}_{2}, \mathrm{PPh}_{3}$, imidazole, THF, $65{ }^{\circ} \mathrm{C}, 87 \%$; (b) $\mathrm{BnOC}(\mathrm{NH}) \mathrm{CCl}_{3}, \mathrm{TfOH}, p$-dioxane, $22{ }^{\circ} \mathrm{C}, 90 \%$; (c) $\mathrm{Zn}, \mathrm{THF}-\mathrm{H}_{2} \mathrm{O}$, ultrasound, $40{ }^{\circ} \mathrm{C}, 90 \%$; (d) homoallylamine, $4 \AA \mathrm{MS}, \mathrm{AcOH}$, $\mathrm{NaCNBH}_{3}$, THF, $0 \rightarrow 22{ }^{\circ} \mathrm{C}, 89 \%$; (e) $\left(\mathrm{CF}_{3} \mathrm{CO}\right)_{2} \mathrm{O}, \mathrm{Et}_{3} \mathrm{~N}, \mathrm{CH}_{2} \mathrm{Cl}_{2}, 0{ }^{\circ} \mathrm{C}$, 93\%; (f) Grubbs' 1st-generation catalyst, benzene, $80{ }^{\circ} \mathrm{C}$, 211a (78\%), 211b (7\%); (g) $\mathrm{CF}_{3} \mathrm{COCH}_{3}$, Oxone, $\mathrm{NaHCO}_{3}, \mathrm{Na}_{2}$ EDTA, $\mathrm{CH}_{3} \mathrm{CN}-\mathrm{H}_{2} \mathrm{O}$, $-10 \rightarrow 0{ }^{\circ} \mathrm{C}$; (h) $\mathrm{KO}-t-\mathrm{Bu}, \mathrm{H}_{2} \mathrm{O}, \mathrm{Et}_{2} \mathrm{O}, 0 \rightarrow 22{ }^{\circ} \mathrm{C}$, 212a $(15 \%), 212 b$ (44\%); (i) $\mathrm{H}_{2}, \mathrm{Pd} / \mathrm{C}, \mathrm{HCl}-\mathrm{MeOH}, 22{ }^{\circ} \mathrm{C}, 94 \%$.

proceeds via formation of a boronate ester and the cyclization of a five- or six-membered cyclic iminium ion intermediate.

Poisson and co-workers recently reported total synthesis of $(+)$-castanospermine stands in contrast to the majority of existing routes to this natural product in that it does not rely on a starting material chosen from the chiral pool (Scheme 35). ${ }^{102}$ Rather, these authors employ the $[2+2]$ cycloaddition of dichloroketene to chiral enol ether 229 in order to establish the $\mathrm{C} 1$ and $\mathrm{C} 8 \mathrm{a}$ stereogenic centers of the target. Asymmetric induction $(\mathrm{dr}=96: 4)$ in this case was mediated by the $(R)$-stericol [1-(2,4,6-triisopropylphenyl)ethanol] alkene substituent. ${ }^{103}$ From cyclobutanone 230, regioselective Beckmann ring expansion, reductive dechlorination and allylic oxdation provided $\gamma$-lactam 231 in high overall yield. After $O$-silylation of 231 and $N$-alkylation using 232, RCM of 1,7-diene $\mathbf{2 3 3}$ generated compound 234. Introduction of the trans-trans triol array was now accomplished by hydroborationoxidation of this enol ether, which afforded a mixture of products 235a and 235b, which were each isolated as single diastereomers $(\mathrm{dr}>95: 5$ ). In the case of $\mathbf{2 3 5} \mathbf{b}$, a sequence of diol protection, lactam reduction and global protecting group/auxiliary removal now provided (+)-castanospermine (205), which was also accessed more directly from 235a, through acid hydrolysis.

Arguably, the most unique non-chiral pool synthesis of castanospermine (205) published during the review period originates from the laboratory of Mariano, who employs a photochemical electrocyclic ring contraction to prepare a carbocyclic substrate from which the piperidine ring of $\mathbf{2 0 5}$ is accessed via a ring rearrangement reaction (RRM) (Scheme 36). ${ }^{104}$ Photocyclization of pyridinium chlorate (236) in water results in the formation of 


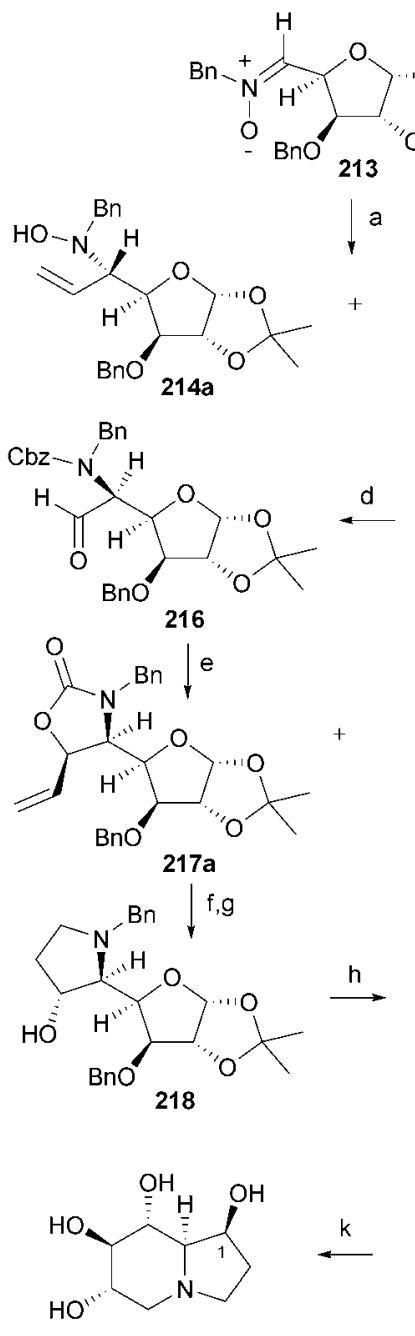

(+)-Castanospermine (205)
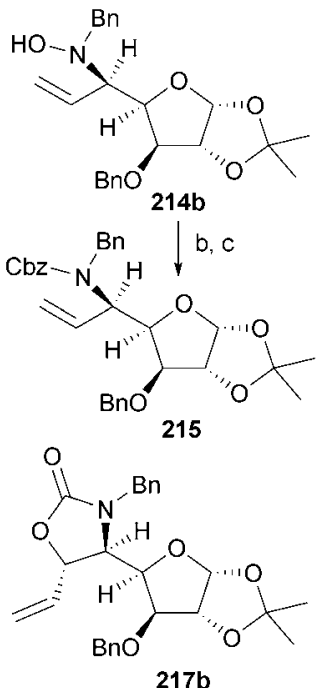

$217 b$

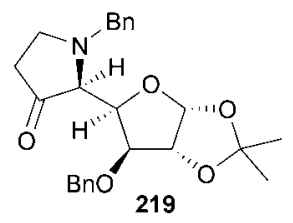

$i, j$

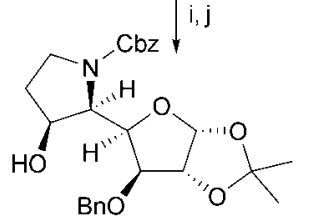

220

Scheme 33 Dhavale's total synthesis of (+)-castanospermine. Reagents and conditions: (a) vinylmagnesium bromide, TMSOTf, THF, $-78^{\circ} \mathrm{C}, 2$ h, $90 \%$; (b) $\mathrm{Zn}, \mathrm{Cu}(\mathrm{OAc})_{2}, \mathrm{AcOH}, 80^{\circ} \mathrm{C}, 1$ h, $88 \%$; (c) $\mathrm{NaHCO}_{3}, \mathrm{CbzCl}$, $\mathrm{MeOH}-\mathrm{H}_{2} \mathrm{O}, 3 \mathrm{~h}, 92 \%$; (d) NMO, $\mathrm{K}_{2} \mathrm{OsO}_{4} \cdot 2 \mathrm{H}_{2} \mathrm{O}$, acetone- $\mathrm{H}_{2} \mathrm{O}(8: 1)$, $12 \mathrm{~h}$; then $\mathrm{NaIO}_{4}$, acetone- $\mathrm{H}_{2} \mathrm{O}(9: 1), 6 \mathrm{~h}, 84 \%$ (2 steps); (e) vinylmagnesium bromide, THF, $-50{ }^{\circ} \mathrm{C}, 1 \mathrm{~h}$; then $\mathrm{KOH}-\mathrm{H}_{2} \mathrm{O}(2: 3), \mathrm{MeOH}$, $90{ }^{\circ} \mathrm{C}, 10 \mathrm{~min}, 77 \%$; (f) $\mathrm{KOH}-\mathrm{H}_{2} \mathrm{O}(2: 3), \mathrm{MeOH}, 90{ }^{\circ} \mathrm{C}, 48 \mathrm{~h}, 98 \%$; (g) $\mathrm{Hg}(\mathrm{OAc})_{2}$, THF- $\mathrm{H}_{2} \mathrm{O}(1: 1), \mathrm{NaBH}_{4}, 3 \mathrm{~h}, 74 \%$; (h) Swern oxidation, $85 \%$; (i) $\mathrm{NaBH}_{4}, \mathrm{MeOH}-\mathrm{H}_{2} \mathrm{O},-60{ }^{\circ} \mathrm{C}$, (10: 1); (j) $\mathrm{NaHCO}_{3}, \mathrm{CbzCl}$, $\mathrm{MeOH}-\mathrm{H}_{2} \mathrm{O}(9: 1), 3 \mathrm{~h}, 70 \%$ (2 steps); (k) TFA- $\mathrm{H}_{2} \mathrm{O}(3: 2), 2.5 \mathrm{~h}, \mathrm{rt}$; then $\mathrm{H}_{2}$ (80 psi), $\mathrm{Pd} / \mathrm{C}(10 \mathrm{~mol} \%), \mathrm{MeOH}, 12 \mathrm{~h}, 85 \%$.

bicyclic aziridinium ion 237, which undergoes solvolysis to provide 4-amino-3,5-cyclopentenediol 238a. As part of an earlier synthesis of the iminosugar swainsonine, Mariano developed a route to enantiomerically enriched 239 from 238a using a sequence involving enzymatic desymmetrization and alcohol inversion. ${ }^{105}$ Employing this advanced building block, treatment with the Grubbs' second-generation catalyst in the presence of ethylene triggered a highly selective RRM reaction to yield allyltetrahydropyridine $\mathbf{2 4 0}$ in excellent yield. After hydroxyldirected epoxidation of the alkene endo face, trans-diaxial opening of epoxide 241 under mild conditions and per- $O$ benzylation provided 242. In preparation for the formation of

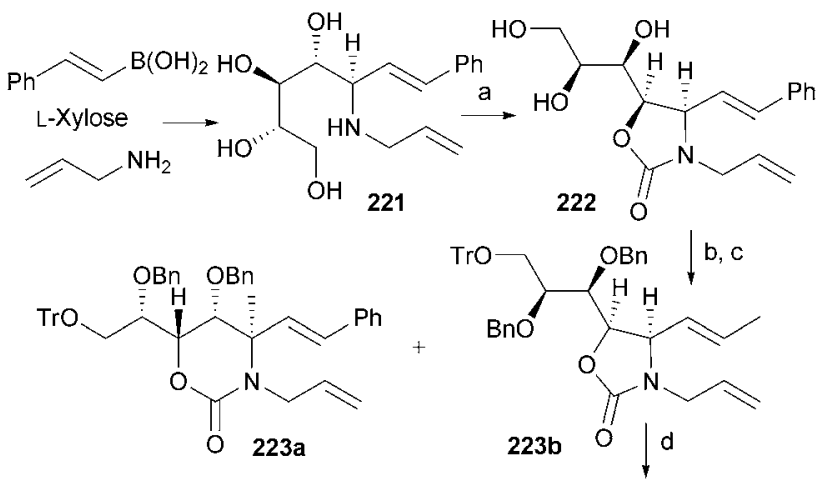

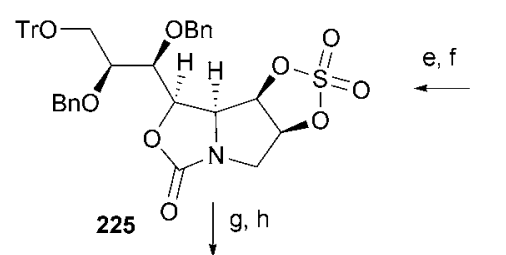

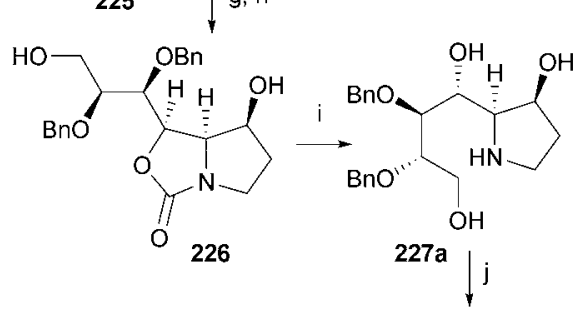<smiles>O=C1O[C@H]([C@H](OCc2ccccc2)[C@@H](Cc2ccccc2)OCc2ccccc2)[C@@H]2C=CCN12</smiles>
$\mathrm{OBn}$<smiles>OC1CO[C@@H](C2NCC[C@H]2O)[C@@H]1O</smiles>

227b

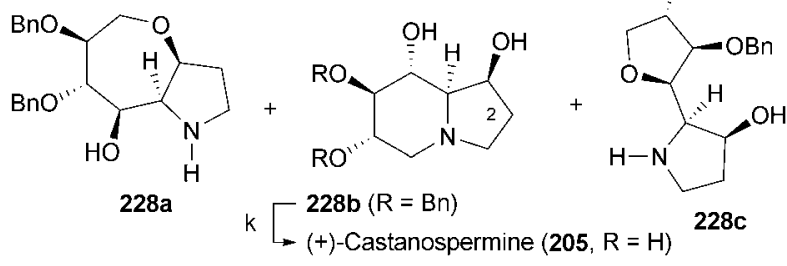

Scheme 34 Pyne's total synthesis of (+)-castanospermine. Reagents and conditions: (a) $\left(\mathrm{Cl}_{3} \mathrm{CO}\right)_{2} \mathrm{CO}, \mathrm{Et}_{3} \mathrm{~N}$, THF, rt, $10 \mathrm{~h}, 53 \%$; (b) TrCl, pyridine, rt, 20 h, 87\%; (c) $\mathrm{NaH}, \mathrm{BnBr}, \mathrm{Bu}_{4} \mathrm{NI}$, THF, $50{ }^{\circ} \mathrm{C}$, 4 d; (d) Grubbs' second-generation catalyst, $\mathrm{CH}_{2} \mathrm{Cl}_{2}$, reflux, $48 \mathrm{~h}, 88 \%$; (e) $\mathrm{K}_{2} \mathrm{OsO}_{4} \cdot 2 \mathrm{H}_{2} \mathrm{O}$, NMO, acetone- $\mathrm{H}_{2} \mathrm{O}$, rt, $48 \mathrm{~h}, 84 \%$, $\mathrm{dr}=83: 17$; (f) $\mathrm{SOCl}_{2}, \mathrm{Et}_{3} \mathrm{~N}, \mathrm{CH}_{2} \mathrm{Cl}_{2}$; then $\mathrm{RuCl}_{3}, \mathrm{NaIO}_{4}, 64 \%$; (g) $\mathrm{NaBH}_{4}$, DMA, rt, 16 h; (h) $\mathrm{H}_{2} \mathrm{SO}_{4}, \mathrm{H}_{2} \mathrm{O}$, THF, rt, $20 \mathrm{~h}, 63 \%$; (i) $\mathrm{NaOH}, \mathrm{H}_{2} \mathrm{O}, \mathrm{MeOH}, 110{ }^{\circ} \mathrm{C}$, $2 \mathrm{~h}$; (j) DIAD, $\mathrm{Ph}_{3} \mathrm{P}$, THF, $0-5{ }^{\circ} \mathrm{C}, 48 \mathrm{~h}, \mathbf{2 2 8 a}(11 \%)$, 228b $(25 \%)$, 229c (22\%); (k) $\mathrm{H}_{2}, \mathrm{PdCl}_{2}, \mathrm{MeOH}, \mathrm{rt}, 1 \mathrm{~h}$; DOWEX-1 ( $\mathrm{OH}^{-}$form), $95 \%$.

the pyrrolidine ring, this material was now submitted to hydroboration-oxidation, which fortuitously also served to remove the $N$-acetyl group. Mitsunobu cyclization followed by hydrogenolysis of the resulting alcohol formed (+)-castanospermine (205).

\section{Sulfonium-sulfate thiosugars}

Iminosugars such as castanospermine (205) are believed to derive their glycosidase binding properties from an ability to mimic the charge and, to some degree, the structure of the oxocarbenium ion-like transition state involved in glycoside hydrolysis (Fig. 11). A requirement for this transition state mimicry is protonation of the ring nitrogen atom within the active site of the enzyme, where electrostatic interaction between the inhibitor ammonium ion and the carboxylate residue(s) have been proposed to play a key 


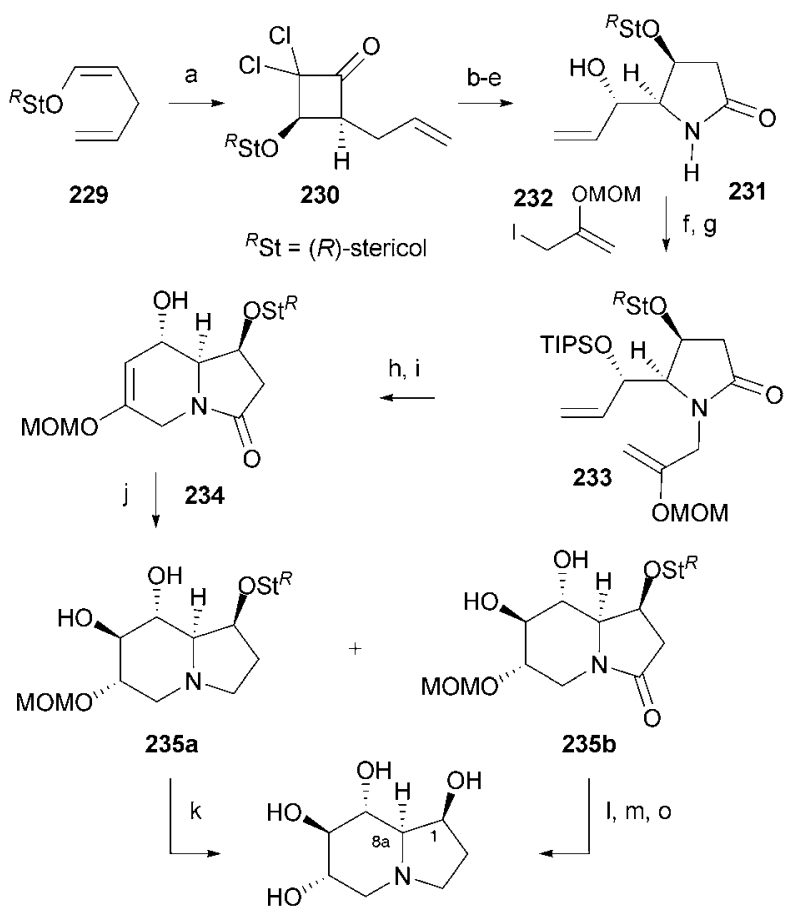

(+)-Castanospermine (205)

Scheme 35 Poisson's total synthesis of (+)-castanospermine. Reagents and conditions: (a) dichloroketene; (b) $O$-mesitylenesulfonylhydroxylamine; then $\mathrm{Zn} / \mathrm{Cu}, \mathrm{H}^{+}, 35 \%$ (5 steps); (c) $\mathrm{SeO}_{2}, 56 \%$, (d) Dess-Martin periodinane, $\mathrm{CH}_{2} \mathrm{Cl}_{2}$, rt, dr (cis/syn : cis/anti) $=1$ : 1; (e) $\mathrm{LiAlH}_{4}, \mathrm{Et}_{2} \mathrm{O}$, $0{ }^{\circ} \mathrm{C} \rightarrow \mathrm{rt}, 82 \%$ (2 steps); (f) TIPSOTf, AcOH; (g) PTC catalyst, 232, 77\%; (h) TBAF, THF, rt; (i) Grubbs' 2nd-generation catalyst, 68\%, (j) $\mathrm{BH}_{3} \cdot \mathrm{SMe}_{2}$, then $\mathrm{NaBO}_{3}, 58 \%$; (k) $\mathrm{HCl}$, EtOH, 93\%; (l) PTSA, 2methoxypropene; (m) $\mathrm{BH}_{3} \cdot \mathrm{SMe}_{2}$; (n) $\mathrm{HCl}$, EtOH, $65 \%$ (3 steps).

role in the activity of iminosugars. Prior to the review period, as part of an effort to design synthetic glycosidase inhibitors which carry a permanent positive charge, Pinto reported the synthesis of the sulfonium-ion castanospermine analogue 244 and found this compound to be a functional inhibitor of glucoamylase. ${ }^{106,107}$ Interestingly, this approach to inhibitor design has not always met with success, as in the case of $\mathbf{2 4 5}$, the $\mathrm{N}$-oxide analogue of castanospermine, which Wong and co-workers have shown to be a weak glycosidase inhibitor in comparison with the natural product. ${ }^{108}$

As previously noted for 1-deoxynojirimycin (1), synthetic chemistry has often pre-empted the isolation of natural products with anti-glycosidase properties. A particularly notable case in this regard has been Pinto's castanospermine studies, which were dramatically validated by Yoshikawa's discovery, beginning in 1997, of a series of naturally occurring glycosidase inhibitors that encompass a zwitterionic sulfonium-sulfate structure (Fig. 12). ${ }^{109}$

Isolated from the aqueous extracts of the roots and stems of Salacia reticulata and related plant species, salicinol (2), ${ }^{110}$ kotalanol (247), ${ }^{111}$ salaprinol (248), ${ }^{112}$ and ponkoranol $(\mathbf{2 4 9})^{112}$ are structurally related in having a 1,4-anhydro-4-thio-D-arabinitol "head" unit and a polyhydroxylated acyclic "tail" of varying length. Immediately attracting the attention of synthetic and medicinal chemists, these novel natural products were found to inhibit intestinal $\alpha$-glucosidases with potencies surpassing that
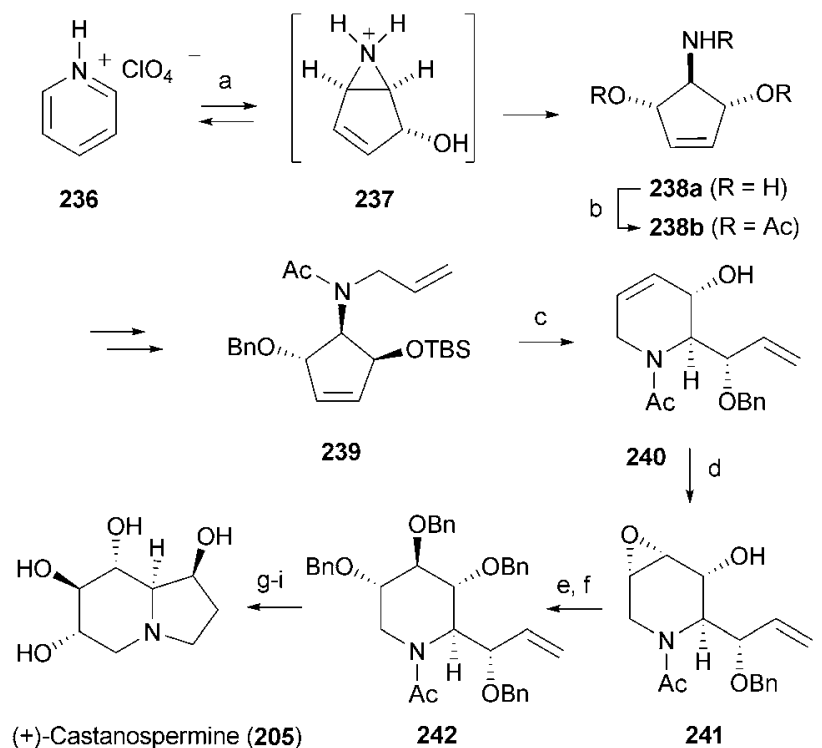

Scheme 36 Mariano's total synthesis of (+)-castanospermine. Reagents and conditions: (a) $\mathrm{h} v, \mathrm{H}_{2} \mathrm{O}, 45-70{ }^{\circ} \mathrm{C}, 48 \mathrm{~h}$; (b) $\mathrm{NaHCO}_{3}$; then $\mathrm{AcCl}$, pyridine, rt, $24 \mathrm{~h}, 22 \%$ (two steps); (b) Grubbs' 2nd-generation catalyst, $\mathrm{CH}_{2}=\mathrm{CH}_{2}, \mathrm{CH}_{2} \mathrm{Cl}_{2}$, reflux, $16 \mathrm{~h}, 93 \%$; (c) $\mathrm{VO}(\mathrm{acac})_{2}(10 \mathrm{~mol} \%), t$ $\mathrm{BuOOH}, 0 \rightarrow 25^{\circ} \mathrm{C}, 5 \mathrm{~h}, 50 \%$; (d) $\mathrm{NaOBz}, \mathrm{H}_{2} \mathrm{O}, 130{ }^{\circ} \mathrm{C}, 12 \mathrm{~h}, 55 \%$; (e) $\mathrm{BnBr}, \mathrm{NaH}, \mathrm{DMF}, 0{ }^{\circ} \mathrm{C}, 2.5 \mathrm{~h}, 94 \%$; (f) $\mathrm{BH}_{3} \cdot \mathrm{THF}, \mathrm{THF}, 0{ }^{\circ} \mathrm{C}, 3 \mathrm{~h}$; then $30 \% \mathrm{H}_{2} \mathrm{O}_{2}, 25^{\circ} \mathrm{C}, 3 \mathrm{~h}, 31 \%$; (g) $\mathrm{PPh}_{3}$, DEAD, THF, $25^{\circ} \mathrm{C}, 12 \mathrm{~h}, 93 \%$; (h) $\mathrm{H}_{2}, \mathrm{PdCl}_{2}, \mathrm{MeOH}-$ EtOAc $(1: 1), 25^{\circ} \mathrm{C}, 4 \mathrm{~h}, 91 \%$.

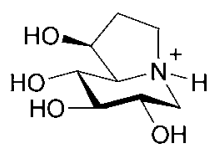

243

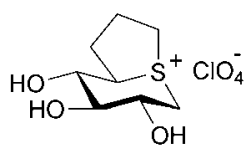

244

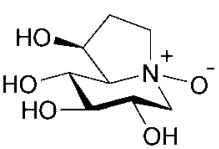

245
Fig. 11 Structure of protonated castanospermine and sulfonium-ion and $\mathrm{N}$-oxide analogues of this naturally occurring glycosidase inhibitor.

of voglibose and ascarbose. Furthermore, human clinical trials on patients with type-2 diabetes mellitus, conducted with extracts of $S$. reticulata, have shown this herbal preparation to be an effective treatment with minimal side effects. ${ }^{113}$ While the specific mode of action of $\mathbf{2}$ and related natural products has yet to be fully delineated, recent co-crystallographic studies of the $N$-terminal domain of human intestinal maltase-glucoamylase (ntMGAM) by Rose and Pinto ${ }^{114}$ suggest that in common with protonated iminosugars, these permanently charged species may mimic the oxocarbenium ion-like transition state of the glucosidase-mediated hydrolysis reaction.

\subsection{Salacinol}

Salacinol (2), the first of the sulfonium-sulfate inhibitors to be discovered, was isolated by Yoshikawa and co-workers in 1997 from the dried roots and stems of Salacia reticulata ("kotala himbutu' in Singhalese), a large climbing plant found throughout the forests of Southern India and Sri Lanka (Fig. 13). ${ }^{110}$ Extracts of this herb, prepared by soaking the bark and roots in water overnight, have long been employed in traditional Indian, or 
<smiles>O=[W]OC(CO)[C@@H](O)CS1=C[C@@H](O)[C@@H](O)[C@H]1CO</smiles>

ent-Salacinol (246)

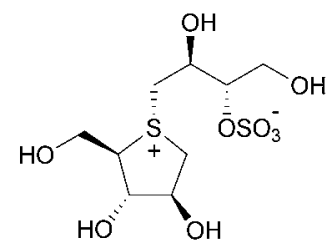

Salacinol (2)<smiles>O=S(=O)(O)O[C@H]([C@H](O)CS1=C[C@@H](O)[C@H](O)[C@H]1CO)[C@@H](O)[C@H](O)CO</smiles>

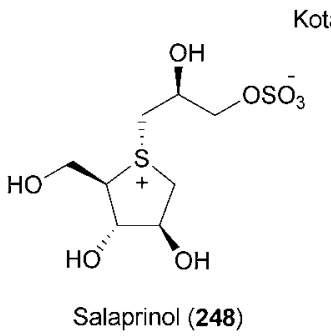

alanol (247)<smiles>O=S(=O)(O)O[C@H]([C@@H](O)C[S]1CC(O)[C@@H](O)[C@H]1CO)[C@H](O)[C@@H](O)CO</smiles>

Fig. 12 Naturally occurring zwitterionic sulfonium-sulfate glucosidase inhibitors: salacinol, kotalanol, salaprinol, and ponkoranol.

Ayurvedic, medicine for the treatment of type II diabetes. ${ }^{115}$ Employing spectroscopic and single crystal X-ray analysis, Yoshikawa initially proposed that salicinol was the inner sulfonium-sulfate salt 246, formed between 1,4-anhydro-4-thio-L-arabinitol and 1-deoxy-D-erythritol-3-sulfate. However, subsequent degradation studies conducted on kotalanol (247) led to a stereochemical revision and the reassignment of the structure of salicinol as D-arabinitol derivative $2 .{ }^{116}$ In vitro analysis of $\mathbf{2}$ has revealed this compound to be an inhibitor of several rat intestinal $\alpha$ glucosidases, including maltase, sucrase and isomaltase $\left(K_{\mathrm{i}}=0.31\right.$, 0.32 and $0.47 \mu \mathrm{M}$, respectively). ${ }^{110,116}$

The first total synthesis of salicinol (2) was reported in 2000 by Yuasa, who generated this sulfonium-sulfate inner salt through $S$-alkylation of 1,4-anhydro-4-thio-D-arabinitol (250) with 251, the cyclic sulfate derivative of isopropylidene-D-erythritol (Scheme 37A). ${ }^{117}$ Reaction at the $S$-center in this case proceeded with complete diastereoselectivity to generate $\alpha$-isomer $\mathbf{2 5 2}$, which was hydrolyzed to provide salicinol in reasonable overall yield. Implementing a similar strategy, but employing $O$-benzyl protecting groups in the 1,4-anhydro-4-thio-arabinitol unit 253, Pinto concurrently developed a synthetic route to $\mathbf{2}$ (Scheme 37B). ${ }^{118}$ While $S$-alkylation of $253(\mathrm{R}=\mathrm{Bn})$ with 253 in acetone proved to be inefficient, Snider and Pinto, through use of 1,1,1,3,3,3-hexafluoroisopropanol (HFIP) as the reaction medium, have subsequently optimized the yield of this step. In the case of $p$-methoxybenzyl (PMB)-protected 253 ( $\mathrm{R}=\mathrm{PMB})$, a quantitative yield of $255(\mathrm{R}=\mathrm{PMB})$ was obtained. ${ }^{119}$ Finding the hydrogenolytic removal of the protecting groups from this sulfonium salt prone to catalyst poisoning, simultaneous removal of the benzylidene acetal and the $p$-methoxybenzyl ethers was conveniently accomplished by solvolysis in aqueous trifluoroacetic acid.

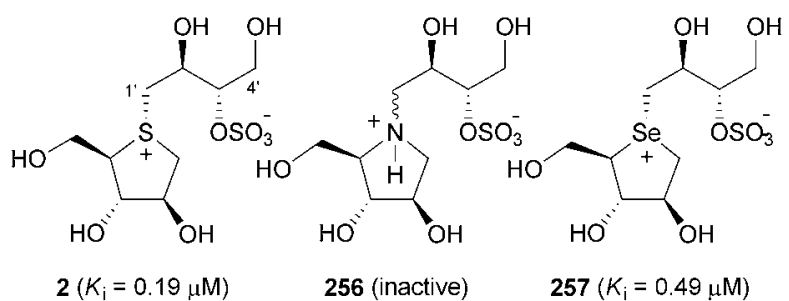<smiles>O=S(=O)(O)[C@H](CO)[C@@H](O)C[S+]1CC(O)[C@@H](O)[C@H](O)C1</smiles><smiles>O=S(=O)(O)[C@H](O)CO</smiles>

258 (inactive)

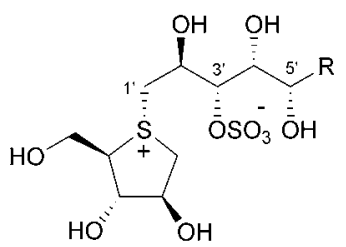

$260\left(\mathrm{R}=\mathrm{H} ; K_{\mathrm{i}}=0.17 \mu \mathrm{M}\right)$ $261\left(\mathrm{R}=\mathrm{CH}_{2} \mathrm{OH} ; K_{\mathrm{i}}=0.17 \mu \mathrm{M}\right)$

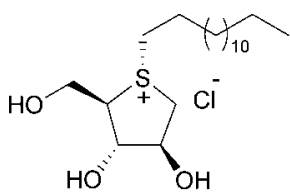

$263\left(K_{\mathrm{i}}=6.0 \mu \mathrm{M}\right)$<smiles>O=S(=O)(O)[C@@H]([C@@H](O)C[13C]1=C[C@@H](O)[C@@H](O)[C@@H]1CO)[C@H](O)CO</smiles>

$262\left(K_{\mathrm{i}}=0.10 \mu \mathrm{M}\right)$<smiles>OC[C@H](O)[C@@H](O)C[Si]1CC(O)[C@@H](O)[C@H]1CO</smiles>

$264\left(\mathrm{IC}_{50}=14.0 \mu \mathrm{M}\right)$

Fig. 13 Structure of salicinol and selected analogues together with their respective $K_{\mathrm{i}}$ values against recombinant human maltase glucoamylase (MGA).

The biological activity of salicinol (2), its unique structure, and the rapidity with which analogues of this natural product can be prepared through recourse to the strategies outlined in Scheme 38, have spurred the groups of Pinto, Muraoka, Yoshikawa and Leamire to conduct extensive structure-activity studies. Since a full discussion of this recently reviewed field is beyond the scope of this article, ${ }^{\mathbf{1 2 0 , 1 2 1}}$ we will limit our commentary to the salient findings of these studies (Fig. 14).

While Pinto ${ }^{122}$ and Muraoka ${ }^{123}$ have found ghavamiol (256), the nitrogen analog of salicinol (2), to be a weak inhibitor of a number of $\alpha$-glucosidases, ${ }^{124}$ the selenium homologue, ${ }^{125}$ blintol (257), displays potent activity against recombinant human maltase glucoamylase (MGA), a key intestinal $\alpha$-glucosidase involved in the breakdown of glucose oligosaccharides. ${ }^{126}$ Employing the strategy outlined in Scheme 38, Pinto ${ }^{127}$ and Lemaire $^{\mathbf{1 2 8}}$ have also independently examined a series of ring analogues of salcinol in order to probe the influence of ring size, substitution and stereochemistry. Notably, both groups have found that departure from the D-arabinitol configuration of the heterocyclic ring, ring expansion (as in the case of 258), ${ }^{128}$ or removal of the $\mathrm{C} 4$ hydroxymethyl group from 2 results in loss of activity. The importance of the five-membered heterocyclic ring 
<smiles>OC[C@H]1SCC(O)[C@H]1O</smiles><smiles>CC1(C)OC[C@H]2OS(=O)(=O)OC[C@H]2O1</smiles>

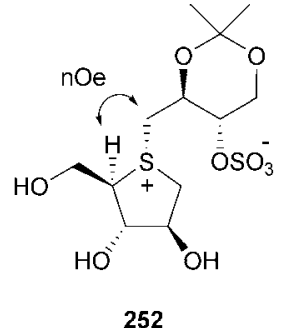

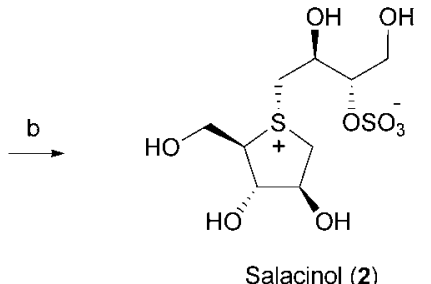

A

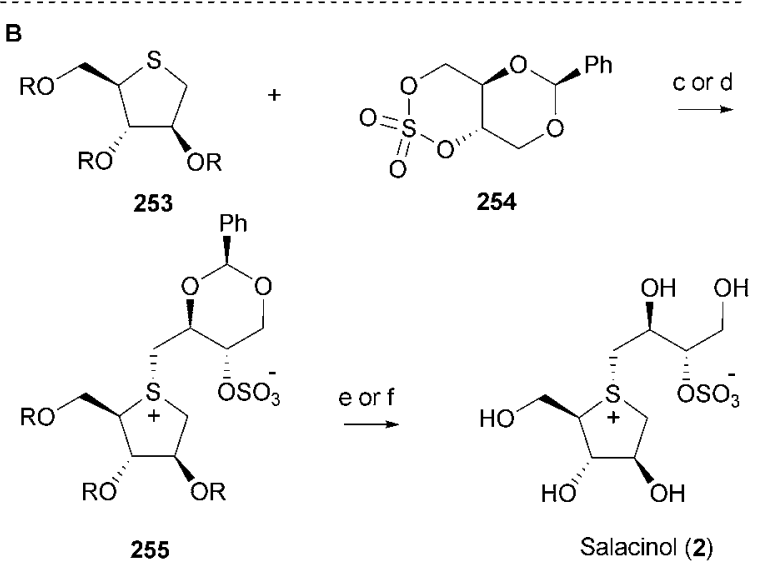

Scheme 37 Yuasa's (A) and Pinto's (B) total syntheses of the naturally occurring $\alpha$-glucosidase inhibitor salacinol. Reagents and conditions: (a) DMF, $45^{\circ} \mathrm{C}, 13 \mathrm{~h}, 61 \%$; (b) $0.01 \% \mathrm{HCl}, 40{ }^{\circ} \mathrm{C}, 4 \mathrm{~h}, 75 \%$; (c) 253 (R = Bn), $\mathrm{K}_{2} \mathrm{CO}_{3}$, acetone, $75^{\circ} \mathrm{C}$ (sealed tube), overnight, $33 \%$; (d) 253 ( $\mathrm{R}=\mathrm{PMB}$ ) HFIP, $\mathrm{K}_{2} \mathrm{CO}_{3}, 55^{\circ} \mathrm{C}$, overnight, $>99 \%$; (e) $255(\mathrm{R}=\mathrm{Bn}), \mathrm{H}_{2}(52 \mathrm{psi}), \mathrm{Pd} /$ $\mathrm{C}, \mathrm{AcOH}-\mathrm{H}_{2} \mathrm{O}(4: 1), 67 \%$; (f) 255 ( $\mathrm{R}=\mathrm{PMB}$ ), TFA- $\mathrm{H}_{2} \mathrm{O}$ (10:1), rt, 30 $\min , 86 \%$.

to the activity of $\mathbf{2}$ is further underscored by the findings of Lemaire $^{129}$ and Pinto ${ }^{130}$ that six-membered deoxynojirimycinsalicinol analogues 259 modeled on migitol are largely inactive towards a range of glucosidases.

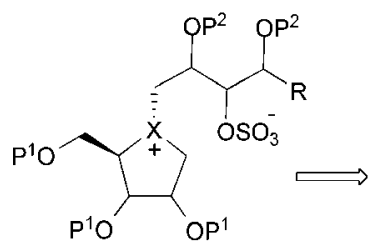

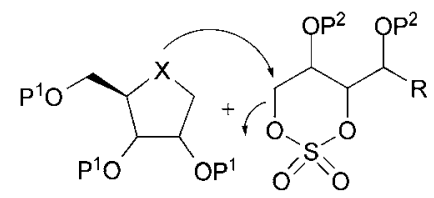

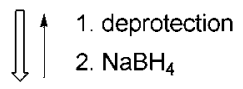

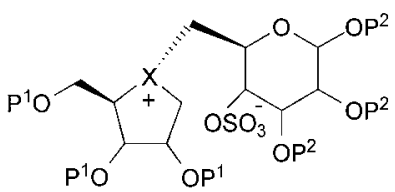<smiles>C=CC=C</smiles><smiles>CCCOC1OC2COS(=O)(=O)OC2C(O)C1OCCO</smiles>

Scheme 38 Regioselective, alkylative ring opening of 1,3-cyclic sulfates with hetero-1,4-anhydroalditols offers an expedient and flexible strategy for the preparation of ring and chain-extended analogues of salicinol.
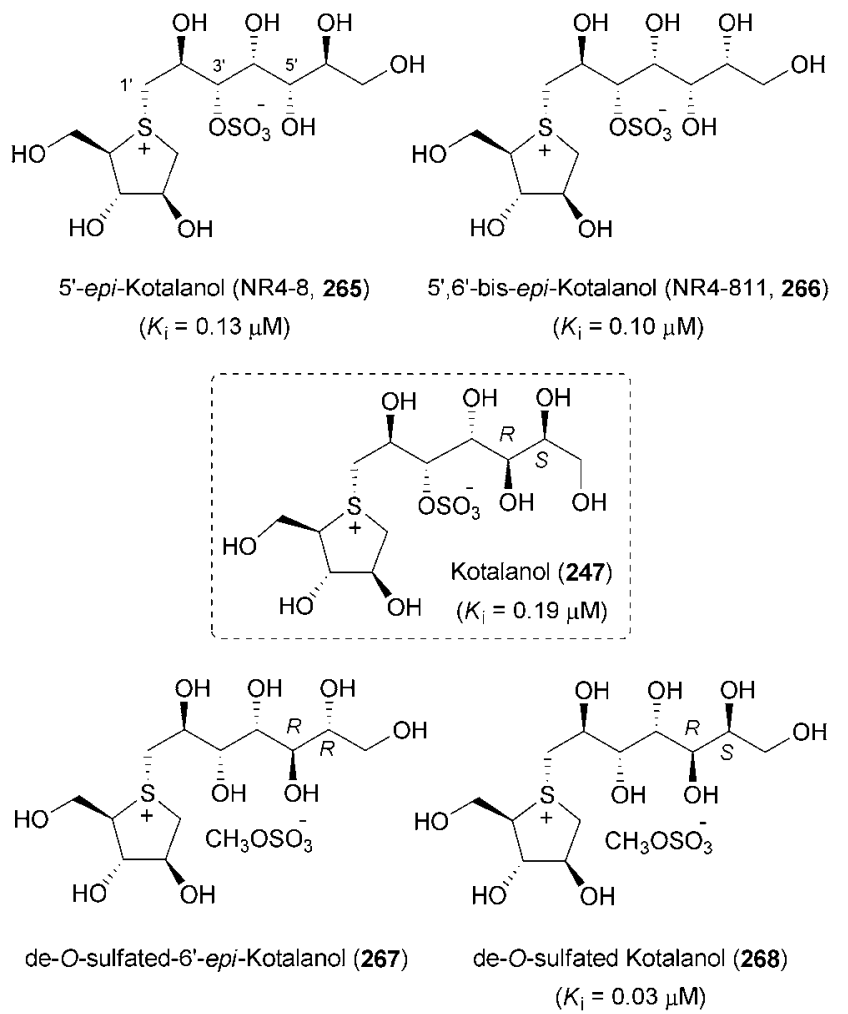

Fig. 14 Structure of seven-carbon chain-extended salicinol analogues designed through analysis of SAR data and synthesized with the intention of determining the stereochemistry of the naturally occurring $\alpha$ glucosidase inhibitor kotalanol (247). Respective $K_{\mathrm{i}}$ values for inhibition of recombinant human maltase-glucoamylase (MGA) are shown. ${ }^{114}$

Since kotalonal (247), which houses a longer side chain than salicinol, is a more potent glucosidase inhibitor, ${ }^{111}$ considerable attention has been paid to the preparation of chain-extended analogs of salicinol (2) and blintol (257). In this regard, Pinto and co-workers have conducted a systematic examination of salicinol homologues possessing 5- and 6-carbon side chains with varying stereochemistry and discovered a number of inhibitors of MGA, including 260, ${ }^{131} 261$ and 262, ${ }^{132}$ which match or exceed the inhibitory activity of salicinol and kotalonal. These studies have revealed that in the series shown, the $S$-configuration at $\mathrm{C}^{\prime}$ and $R$-configuration at $\mathrm{C}^{\prime}$ are critical for activity, while the relative configuration of the sulfate-bearing $\mathrm{C} 3^{\prime}$ stereocenter is unimportant. Intriguingly, simple $S$-alkylated sulfonium salts of 1,4anhydro-4-thio-D-arabinitol, as exemplified by $\mathbf{2 6 3}$, are also inhibitors of MGA. ${ }^{133,134}$ Pinto's findings in this regard appear to be in accord with those of Muraoka and co-workers, who, finding that neosalicinol (264) (the de- $O$-sulfonated derivative of salacinol) displays comparable activity against rat intestinal maltase to the natural product itself $\left(\mathrm{IC}_{50}=9.6 \mu \mathrm{M}\right)$, concluded that the $O$-sulfate anion is unnecessary for inhibitory activity. ${ }^{135}$

\subsection{Kotalanol}

In addition to salicinol (2), the aqueous extracts of Salacia reticulata have yielded a number of other bioactive components, including kotalanol (247), ${ }^{111}$ which displays more potent $\alpha$-glucosidase 
inhibitory activity ( $K_{\mathrm{i}}$ : maltase, $0.23 \mu \mathrm{g} / \mathrm{mL}$; sucrase, $0.18 \mu \mathrm{g} / \mathrm{mL}$ ) than $2\left(K_{\mathrm{i}}\right.$ : maltase, $0.31 \mu \mathrm{g} / \mathrm{mL}$; sucrase, $0.32 \mu \mathrm{g} / \mathrm{mL}$ ) (Scheme 39). From a structural perspective, 247 differs from salicinol in that it bears a heptitol rather than an alditol side chain and consequently has three additional stereocenters. Although the stereochemistry of the 1-deoxy-4-thiopento-furanosyl moiety was originally determined by Yoshikawa through degradation studies, ${ }^{111}$ the absolute stereochemistry of the heptitol side chain and $S$-stereocenter of $\mathbf{2 4 7}$ remained unknown until 2008-2009, when Pinto published two reports concerning the structural elucidation and total synthesis of this medicinally important natural product.

Pinto's initial efforts to determine the side-chain stereochemistry of kotalanol (247) focused on establishing the common stereochemical motif necessary for inhibitory activity against recombinant human maltase-glucoamylase (MGA) (Fig. 14). ${ }^{136}$ Through examination of a library of existing five- and six-carbon salicinol analogues, it was determined that compounds bearing the $S$-configuration at $\mathrm{C}^{\prime}$ and $\mathrm{C}^{\prime}$, and the $R$-configuration at $\mathrm{C}^{\prime}$ ', were most active. Based on this bioassay-guided analysis, chain-extended salicinol analogues 265 and 266 were selected as potential kolatanol candidates and synthesized. Unfortunately, while the inhibitory activity of these compounds was found to be

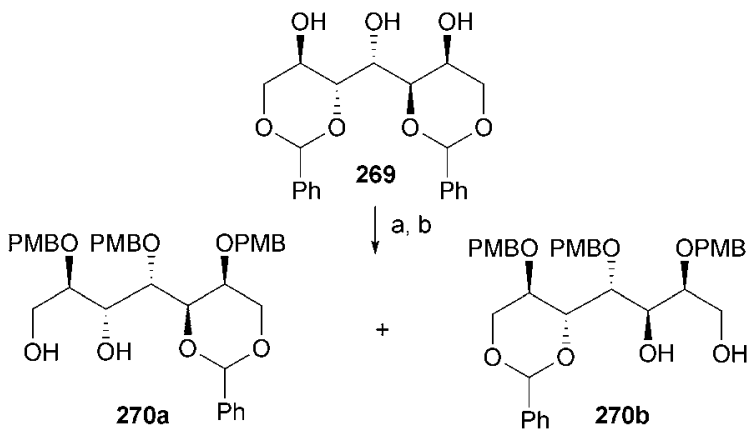
c, d
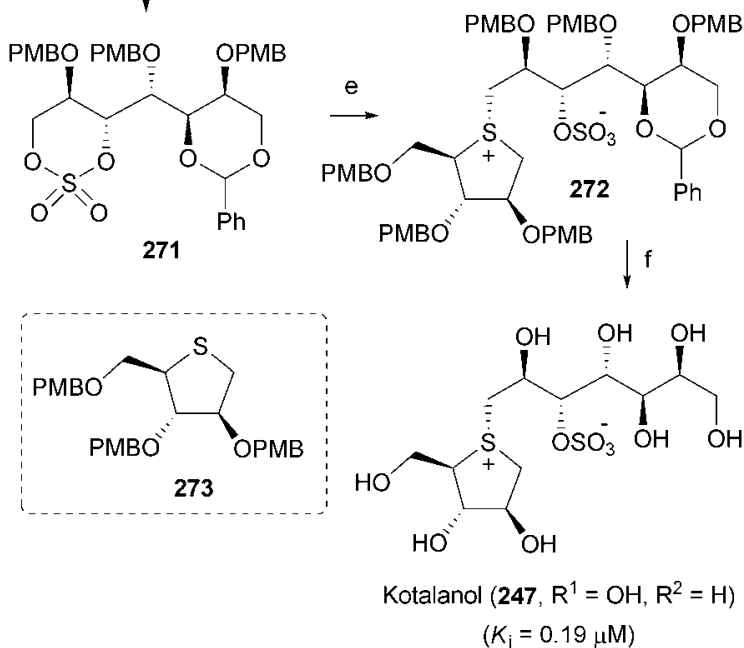

Scheme 39 Pinto's total synthesis of kotalanol. Reagents and conditions: (a) $\mathrm{PMBCl}, \mathrm{NaH}, \mathrm{DMF}, 0{ }^{\circ} \mathrm{C} \rightarrow \mathrm{rt}, 2 \mathrm{~h}$; (b) $p$-TSA, MeOH, rt, $30 \mathrm{~min}$, 270a (44\%), 270b (34\%); (c) $\mathrm{SOCl}_{2}, \mathrm{Et}_{3} \mathrm{~N}, \mathrm{CH}_{2} \mathrm{Cl}_{2}$; (d) $\mathrm{NaIO}_{4}, \mathrm{RuCl}_{3}$, $\mathrm{CCl}_{4}-\mathrm{CH}_{3} \mathrm{CN}, 77 \%$ (2 steps); (e) 273 , HFIP, $\mathrm{K}_{2} \mathrm{CO}_{3}, 75^{\circ} \mathrm{C}, 7 \mathrm{~d}, 69 \%$; (f) TFA, $\mathrm{CH}_{2} \mathrm{Cl}_{2}, \mathrm{H}_{2} \mathrm{O}$, rt, $2 \mathrm{~h}, 93 \%$. comparable to kolatanol, small discrepancies between the ${ }^{1} \mathrm{H}$ and ${ }^{13} \mathrm{C}$ NMR spectral data of these synthetic products and 247 indicated that neither was kolatanol. On the basis of detailed analysis of NMR data collected from 265 and 266, Pinto concluded that the configuration at $\mathrm{C}^{\prime}$ in the natural product was in fact $R$.

In light of these findings, Pinto and co-workers have recently synthesized the de- $O$-sulfated $\mathrm{C}^{\prime}$ epimers 267 and 268 from D-mannitol (for details, see Section 4.3) and found the physical data collected from the latter compound to closely match that reported for naturally derived de- $O$-sulfonated kolatanol. Having thus formally confirmed the elusive structure of kotalanol by inference, Pinto prepared the natural product itself from D-perseitol, ${ }^{137}$ a heptitol found in various parts of the avocado plant and its fruit (Scheme 40).

Commencing from D-perseitol derivative 269, ${ }^{138} \mathrm{O}$-benzylation and hydrolysis of this bis-benzylidene acetal generated a near-equal
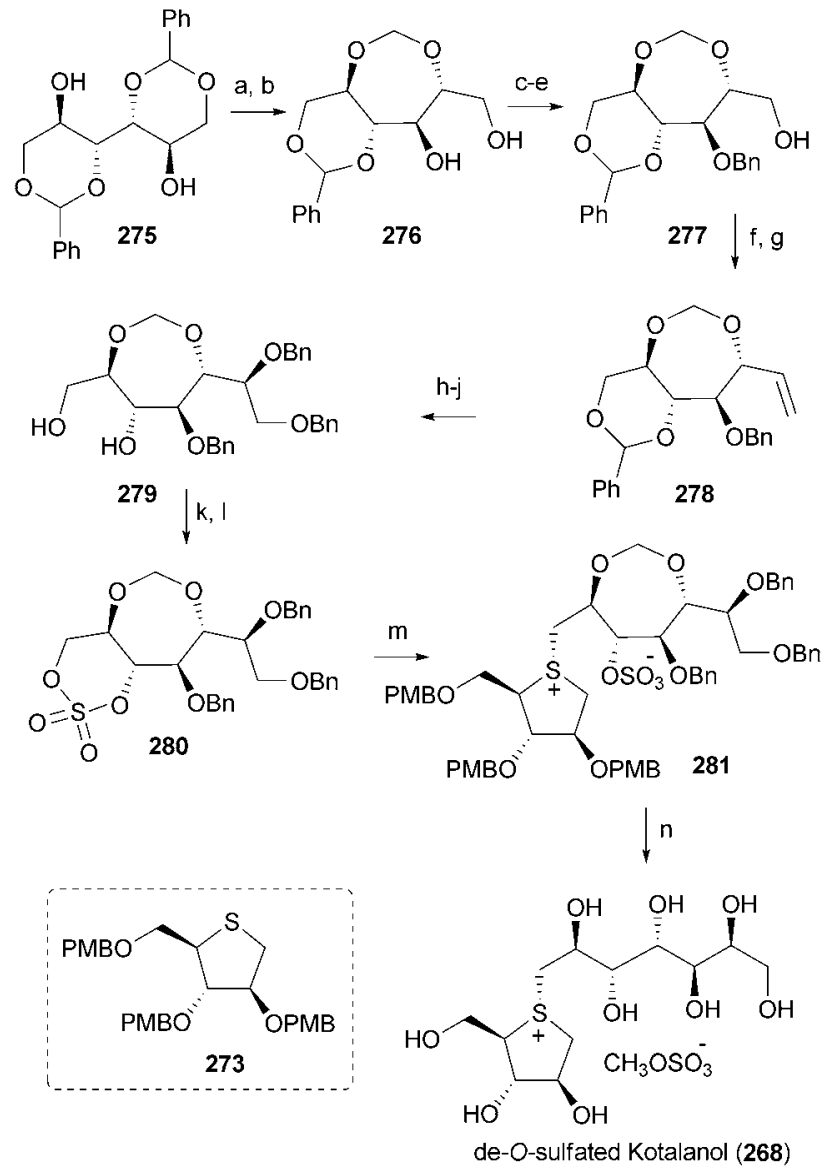

Scheme 40 Pinto's total synthesis of de- $O$-sulfonated kotalanol. Reagents and conditions: (a) $\mathrm{CH}_{2} \mathrm{Br}_{2}, \mathrm{NaOH}-\mathrm{H}_{2} \mathrm{O}$; (b) $p$-TSA, $\mathrm{MeOH}$, $70{ }^{\circ} \mathrm{C}, 2 \mathrm{~h}, 65 \%$ (2 steps); (c) TBSCl, imidazole, DMF, $0{ }^{\circ} \mathrm{C}, 2 \mathrm{~h}$; (d) BnBr, $\mathrm{NaH}, \mathrm{rt}, 1 \mathrm{~h}$; (e) TBAF, THF, rt, 20 h, 62\% (3 steps); (f) Dess-Martin periodinane, $\mathrm{CH}_{2} \mathrm{Cl}_{2}, \mathrm{NaHCO}_{3}$, rt, $15 \mathrm{~min}$; (g) $\mathrm{CH}_{3} \mathrm{PPh}_{3} \mathrm{Br}, n-\mathrm{BuLi}$, THF, $-78{ }^{\circ} \mathrm{C} \rightarrow \mathrm{rt}$, overnight, $56 \%$ (2 steps); (h) AD-mix $\beta, t$-BuOH$\mathrm{H}_{2} \mathrm{O}(1: 1), 0{ }^{\circ} \mathrm{C}, 7 \mathrm{~d}, 64 \%$; (i) $\mathrm{BnBr}, \mathrm{NaH}, \mathrm{DMF}, \mathrm{rt}, 2 \mathrm{~h}$; (j) $p$-TSA, $\mathrm{MeOH}, \mathrm{rt}, 24 \mathrm{~h}, 77 \%$ (2 steps); (k) $\mathrm{SOCl}_{2}, \mathrm{Et}_{3} \mathrm{~N}, \mathrm{CH}_{2} \mathrm{Cl}_{2}, 0{ }^{\circ} \mathrm{C}$, $45 \mathrm{~min}$; (l) $\mathrm{NaIO}_{4}, \mathrm{RuCl}_{3}, \mathrm{CCl}_{4}-\mathrm{CH}_{3} \mathrm{CN}$ (1: 1), $\mathrm{H}_{2} \mathrm{O}, \mathrm{rt}, 2 \mathrm{~h}, 64 \%$ (2 steps); (m) 273, HFIP, $\mathrm{K}_{2} \mathrm{CO}_{3}, 75^{\circ} \mathrm{C}, 7 \mathrm{~d}, 61 \%$; (n) $\mathrm{BCl}_{3}, \mathrm{CH}_{2} \mathrm{Cl}_{2},-78{ }^{\circ} \mathrm{C} \rightarrow \mathrm{rt}, 12 \mathrm{~h}$, $61 \%$. 
mixture of 270a and 270b, which were separated chromatographically. Moving forward with 270a, this 1,3-diol was converted to the corresponding cyclic sulfate 271 and coupled with PMB-protected 1,4-dideoxy-1,4-imino-L-arabinitol 273 in HFIP to generate sulfonium ion $\mathbf{2 7 2}$ as a single diastereomer. Simultaneous removal of seven protecting groups using aqueous TFA then provided kotalanol (247) in high yield. The apparent simplicity of Pinto's synthetic route to kotalanol belies both the complexity of the underlying structural elucidation problem, which remained unresolved for more than a decade, and the fact that, before the preparation of the natural product itself was possible, the synthesis of a sizeable library of salicinol and kolatanol analogues was necessary.

\subsection{De- $O$-sulfonated kotalanol}

Since it has been estimated that salcinol and kotalanol only account for approximately $10 \%$ of the $\alpha$-glucosidase inhibitory activity associated with the water-soluble extracts of Salicia spp., the search for other bioactive constituents in these herbal medicine has not abated. In this regard, Ozaki and co-workers recently reported the isolation of further $\alpha$-glucosidase inhibitor from $S$. reticulata and assigned its structure as the unusual 13-membered cyclic sulfoxide 274 (Fig. 15). ${ }^{139}$ Subsequent reevalaution of Ozaki's data by Koshikawa and co-workers has led to the conclusion that this compound is in fact de- $O$-sulfated kotalanol (268), ${ }^{140}$ which Koshikawa has previously prepared via the desulfonylation of kotalanol. ${ }^{141}$ Structural ambiguity notwithstanding, Ozaki has not only shown that $\mathbf{2 6 8}$ is the most potent inhibitor of rat intestinal $\alpha$-glucosidase isolated from Salicia spp. to date, but also displays anti-hyperglycemic activity in vivo: administration of $\mathbf{2 6 8}$ to rats leads to significant lowering of postprandial (post-meal) glucose levels through inhibition of intestinal maltase and sucrase. ${ }^{142}$ More recent studies by Rose and Pinto have revealed that $\mathbf{2 6 8}$ is also a potent inhibitor of human intestinal maltase-glucoamylase (MGAM). ${ }^{114}$

With the exception Koshikawa's degradation study noted above, to date only one total synthesis of de- $O$-sulfonated kotalanol (268) has been reported, by Pinto and co-workers, who prepared this compound as part of their recent structural elucidation of kotalanol (247). In this case, synthesis commenced from di- $O$-benzylidene-D-mannitol (275), which underwent bis$O$-alkylation with dibromomethane under phase transfer conditions to provide a $C_{2}$-symmetric 1,3-dioxepane derivative. Methanolysis of a single benzylidene acetal under acid conditions then generated 1,3-diol 276, which through a succession of
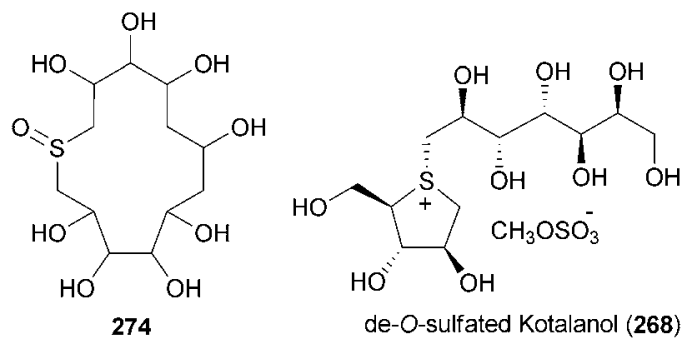

Fig. 15 Initially proposed and reassigned structures of the naturally occurring $\alpha$-glucosidase inhibitor de- $O$-sulfonated kotalanol. silylation, $O$-benzylation and desilylation was converted to primary alcohol 277. Dess-Martin oxidation and Wittig homologation of the aldehyde generated terminal alkene $\mathbf{2 7 8}$. Introduction of the $\mathrm{C}^{\prime}$ stereocenter of the target was accomplished by Sharpless asymmetric dihydroxylation using AD-mix $\beta$, which proceeded to generate a $7: 1$ mixture of diastereomeric diols. After chromatographic separation, the major product was bis- $O$-alkylated and the remaining benzylidene acetal hydrolyzed to provide 279.

Conversion of 1,3-diol 279 to the corresponding cyclic sulfate now set the stage for coupling with $\mathbf{2 7 3}$, which proceeded slowly (7 d) in HFIP to generate sulfonium salt $\mathbf{2 8 1}$ as a single $\alpha$-isomer. In light of the stability of the 1,3-dioxepane ring towards aqueous TFA, simultaneous removal of all protecting groups and desulfonylation was now carried out with $\mathrm{BCl}_{3}$, which furnished de- $O$ sulfated kotalanol as the methyl sulfate salt $\mathbf{2 6 8}$.

\subsection{Salaprinol}

Isolated from the methanolic extract of the roots and stems of the Sri Lankan plant Salacia prinoides, salaprinol (248) is the least structurally complex of the zwitterionic thiosugar $\alpha$-glucosidase inhibitors discovered to date (Scheme 41) ${ }^{141}$ Confirmation of the structure and stereochemistry of this natural product has been accomplished by Muraoka, through total synthesis and single crystal X-ray analysis. ${ }^{143}$
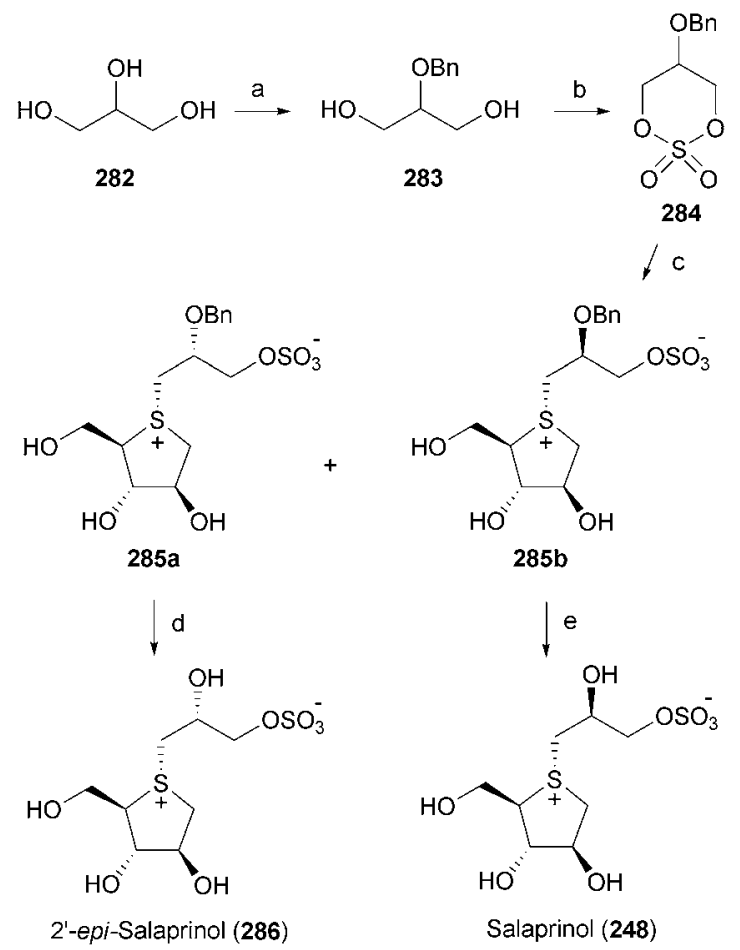

Scheme 41 Muraoka's synthesis of $2^{\prime}$-epi-salaprinol and salaprinol. Reagents and conditions: (a) (i) $\mathrm{TrCl}$, pyridine, rt, $24 \mathrm{~h}$; (ii) $\mathrm{BnBr}, \mathrm{NaH}$, DMF, $0{ }^{\circ} \mathrm{C} \rightarrow \mathrm{rt}$; (iii) $\mathrm{H}_{2} \mathrm{SO}_{4}$, 1,4-dioxane, reflux, $2 \mathrm{~h}, 90 \%$ (3 steps); (b) $\mathrm{SOCl}_{2}, \mathrm{Et}_{3} \mathrm{~N}, \mathrm{CH}_{2} \mathrm{Cl}_{2}, 0^{\circ} \mathrm{C}, 10 \mathrm{~min}$; then $\mathrm{NaIO}_{4}, \mathrm{RuCl}_{3}, \mathrm{NaHCO}_{3}, \mathrm{CCl}_{4-}$ $\mathrm{CH}_{3} \mathrm{CN}(1: 1), \mathrm{H}_{2} \mathrm{O}, 0{ }^{\circ} \mathrm{C} \rightarrow \mathrm{rt}, 30 \mathrm{~min}, 93 \%$ (2 steps); (c) 1,4-anhydro-4thio-D-arabinitol (250), $\mathrm{K}_{2} \mathrm{CO}_{3}$, $\mathrm{HFIP}, 65-70{ }^{\circ} \mathrm{C}, 60 \mathrm{~h}, 43 \%$; (d) $\mathrm{H}_{2}, \mathrm{Pd} / \mathrm{C}$, $80 \% \mathrm{AcOH}, \mathrm{rt},<86 \%$; (e) $\mathrm{H}_{2}, \mathrm{Pd} / \mathrm{C}, 80 \% \mathrm{AcOH}, \mathrm{rt}, 87 \%$. 
Synthesis of $\mathbf{2 4 8}$ commenced from glycerol (282), which through a 3-step, one-pot sequence involving 1,3-di-O-tritylation, $O$ benzylation and solvolysis, was converted to 2-O-benzyl-glycerol (283) (Scheme 41). This 1,3-diol was then converted to meso cyclic sulfate 284, which underwent slow $S$-alkylation with unprotected 1,4-anhydro-4-thio-D-arabinitol (250) exclusively from the $\alpha$-face to generate a $10: 1$ mixture of $\mathrm{C} 2^{\prime}$-epimers. After partial separation, hydrogenolytic de- $O$-benzylation of $\mathbf{2 8 5 a}$ and $\mathbf{2 8 5} \mathbf{b}$ provided $2^{\prime}$-epi-salaprinol (286) and salaprinol (248), respectively.

\subsection{Ponkoranol}

Ponkoranol (249), a six-carbon chain homologue of salacinol (2) initially isolated from Salacia reticulata by Kitamura, ${ }^{144}$ who named it reticulanol, has more recently been found to occur in Salacia prinoides by Yoshikawa. In common with other members of the thiosugar sulfonium sulfate family, ponkoranol inhibits maltase, sucrase and isomaltase with $\mathrm{IC}_{50}$ values in the low micromolar range. ${ }^{145}$ To date, a single synthesis of $\mathbf{2 4 9}$ has been reported, by Pinto and co-workers who, while conducting SAR studies on salacinol, prepared this compound prior to the original report of its isolation (Scheme 42). ${ }^{131}$

Preparation of 249 was accomplished by the regioselective alkylation of thioether $\mathbf{2 5 3}$ with cyclic sulfate $\mathbf{2 8 8}$, which was prepared from D-glucopyranoside $\mathbf{2 8 7}$ through the two-step method developed by Sharpless. ${ }^{146}$ Alkylation of $\mathbf{2 8 8}$ proceeded slowly in HFIP to generate sulfonium salt $\mathbf{2 8 9}$ as a single trans isomer, albeit in moderate yield. A sequence of hydrogenolytic debenzylation and reduction of the resulting mixture of hemiacetal anomers with $\mathrm{NaBH}_{4}$ then generated ponkoranol (249).

\subsection{Neosalacinol}

Neosalacinol (291) and salicinol (2) were recently isolated from the medicinal plant Salacia oblanga by Asano and co-workers (Scheme 43). On the basis of NMR spectroscopic analysis, mass spectrometry and a degradation study, the identity of 291 was established as a de-sulfonated derivative of salicinol and

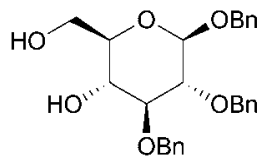

287

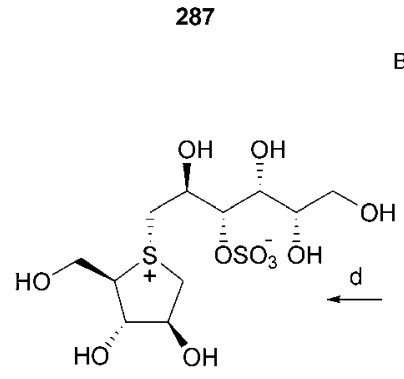

Ponkoranol (249)

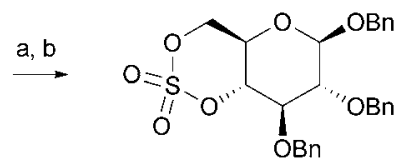

288

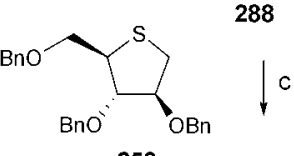

253

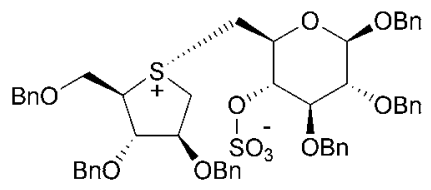

289
Scheme 42 Pinto's total synthesis of ponkoranol. Reagents and conditions: (a) $\mathrm{SO}_{2} \mathrm{Cl}_{2}, \mathrm{Et}_{3} \mathrm{~N}, \mathrm{CH}_{2} \mathrm{Cl}_{2}, \mathrm{rt}, 80 \%$; (b) $\mathrm{NaIO}_{4}, \mathrm{RuCl}_{3} \cdot \mathrm{H}_{2} \mathrm{O}$ (cat.), $\mathrm{CCl}_{4}-\mathrm{CH}_{3} \mathrm{CN}$ (1: 1), rt, $15 \mathrm{~min}$; (c) HFIP, $70{ }^{\circ} \mathrm{C}, 42 \mathrm{~h}, 50 \%$; (d) $\mathrm{H}_{2}$ (1 atm), $\mathrm{Pd} / \mathrm{C}, \mathrm{AcOH}, 22 \mathrm{~h}$; then $\mathrm{NaBH}_{4}, \mathrm{H}_{2} \mathrm{O}, \mathrm{rt}, 20 \mathrm{~min}, 64 \%$. formulated its structure in terms the sulfonium-alkoxide zwitterion 290 (Fig. 16). ${ }^{147}$ Subsequent synthetic studies by Muraoka have revealed that while $\mathbf{2 9 1}$ is indeed de- $O$-sulfo-salicinol, it is not an inner salt. ${ }^{148}$ Confusion regarding its ionic structure aside, compound 291 is notable in that it displays differential activity with respect to salicinol. Of these two molecules, 291 is the more potent inhibitor of rat intestinal isomaltase $\left(\mathrm{IC}_{50}=0.64 \mu \mathrm{M}\right)$, while 2 is more active against maltase $\left(\mathrm{IC}_{50}=0.5 \mu \mathrm{M}\right)$ and human lysosomal $\alpha$-glucosidase, an essential mediator in the breakdown of glycogen to glucose.

In order to clarify the structure of this highly potent glucosidase inhibitor, Muraoka has developed a synthetic route to 291, which involves the acid-catalyzed reaction of thioether 253 with epoxide 292. In what is likely a reflection of the smaller size of this electrophile, in comparison with cyclic sulfates, $S$-alkylation in this case proceeded to generate a mixture of $\beta$-hydroxylated sulfonium salts $(\mathrm{dr}=9: 1)$ in favor of the anti-isomer. After chromatographic separation, 293a was subjected to ion exchange $\left(\mathrm{BF}_{4}{ }^{-} \rightarrow \mathrm{Cl}^{-}\right)$and hydrogenolysis to yield sulfonium chloride 263. Treatment with Dowex $1-\mathrm{X} 2\left(\mathrm{HCO}_{2}{ }^{-}\right.$form $)$then generated formate salt 291, whose spectroscopic data was in accord with that of the original isolate.

Muraoka has also prepared neosalicinol through the methanolysis of salincinol itself (Scheme 44). In common with Asano, ${ }^{147}$ heating 2 in $5 \%$ methanolic $\mathrm{HCl}$ was found to generate the methyl sulfate salt in high yield. Ion exchange with Dowex 1$\mathrm{X} 2\left(\mathrm{HCO}_{2}{ }^{-}\right.$form $)$then generated formate salt 291, which was identical to synthetic material. Whether neosalicinol is simply an artifact of the isolation of salicinol is a question which, as yet, remains unanswered.
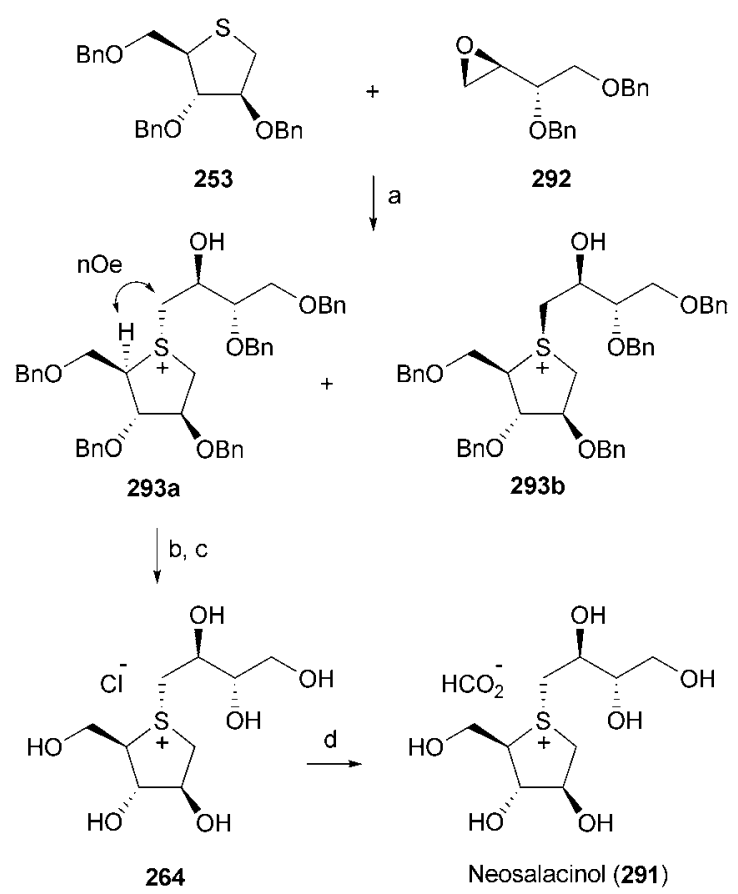

Scheme 43 Muraoka's total synthesis and structural reassignment of neosalicinol (de- $O$-sulfated salacinol). Reagents and conditions: (a) $\mathrm{HBF}_{4} \cdot \mathrm{OMe}_{2}, \mathrm{CH}_{2} \mathrm{Cl}_{2},-60{ }^{\circ} \mathrm{C}, 90 \%, \mathrm{dr}=9: 1$; (b) IRA-400J $\left(\mathrm{Cl}^{-}\right.$form), $\mathrm{MeOH}-\mathrm{H}_{2} \mathrm{O}$, rt, $95 \%$; (c) $\mathrm{H}_{2}, \mathrm{Pd} / \mathrm{C}, \mathrm{AcOH}-\mathrm{H}_{2} \mathrm{O}(4: 1), 50-60{ }^{\circ} \mathrm{C}, 90 \%$; (d) Dowex 1-X2 $\left(\mathrm{HCO}_{2}{ }^{-}\right.$form $), \mathrm{H}_{2} \mathrm{O}$. 
<smiles>OC[C@H](O)[C@@H](O)C[S]1CC(O)[C@H](O)[C@H]1CO</smiles><smiles>O=[N+]([O-])O[C@H](O)[C@@H](O)C[SH]1C[C@H](O)[C@@H](O)[C@H]1CO</smiles>

Fig. 16 Initially proposed and reassigned structures of the $\alpha$-glucosidase inhibitor neosalicinol.
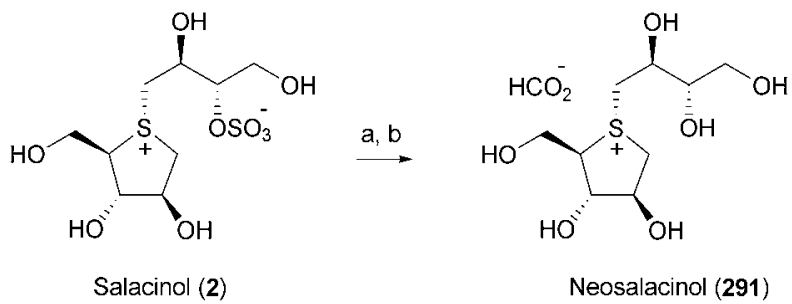

Scheme 44 Muraoka's synthesis of de- $O$-sulfated salacinol through salacinol degradation. Reagents and conditions: (a) $\mathrm{MeOH}-\mathrm{HCl}(95: 5)$, reflux, $1 \mathrm{~h}, 88 \%$; (b) Dowex 1-X2 $\left(\mathrm{HCO}_{2}^{-}\right.$form), $\mathrm{H}_{2} \mathrm{O}, 82 \%$.

\section{Carbasugars}

First synthesized by McCasland and co-workers in 1966, carbasugars (or pseudosugars) are carbocyclic analogues of monosaccharides in which the ring-oxygen atom has been replaced by a methylene group. ${ }^{149}$ In common with deoxynojirimycin, this seminal synthetic work actually predates, by seven years, the discovery of the first carbasugar natural product, 5a-carba- $\alpha$ D-galactopyranose (294) (Fig. 17). ${ }^{150}$ While rarely found in
Nature alone, carbasugars and in particular aminocyclitols more commonly occur as components of more complex natural products, as exemplified by the aminoglycoside antibiotic validamycin (297). ${ }^{151}$ Within the scope of the current review, the aminocyclitols valienamine (295), valiolamine (296), validamine (299) and their derivatives voglibose (298) and acarbose (300) are of particular note since they are potent $\alpha$-glucosidase inhibitors. Indeed, acarbose and voglibose, which are respectively marketed as Precose ${ }^{\circledR}$ and Basen ${ }^{\circledR}$, are approved for the clinical treatment of type II diabetes. The obvious importance of aminocyclitols coupled with their limited availability from natural sources has motivated a considerable amount of work directed towards their preparation. $^{152}$

\subsection{Valienamine}

Found as a subunit of a number of pseudo-oligosaccharides and pseudo-aminosugars, including acarbose, adiposins, amylostatins and trestatins, ${ }^{151}$ the potent $\alpha$-glucosidase inhibitor and antibiotic valienamine (295) was originally obtained from the microbial deglycosylation of validoxylamine A with Pseudomonas denitrificans. ${ }^{153}$ Since its isolation in 1972, several elegant syntheses of this aminocyclitol have reported, many of which employ D-glucose or its derivatives as the starting point. In this vein, Kim and Jeon have developed a concise, nine-step synthesis of pentaacetate (307) from tetra- $O$-benzyl-D-glucose (301), which utilizes $\mathrm{RCM}$ to establish the cyclohexenyl ring (Scheme 45). ${ }^{154}$ Treatment of 301 with ethanethiol and TFA yielded hydroxy dithioacetal 302, which underwent Albright-Goldman oxidation $\left(\mathrm{Ac}_{2} \mathrm{O}-\mathrm{DMSO}\right)$ to yield the corresponding ketone. Wittig methylenation, thioacetal hydrolysis and addition of vinylmagnesium bromide to the aldehyde generated 304 as an inseparable mixture of diastereomers. RCM of these 1,7-dienes proceeded in the presence of Grubbs'<smiles>OC[C@H]1C[C@@H](O)[C@H](O)[C@H](O)[C@@H]1O</smiles>

294<smiles>N[C@H]1C=C(CO)[C@@H](O)[C@H](O)[C@@H]1O</smiles>

Valienamine (295)<smiles>N[C@H]1C[C@](O)(CO)[C@@H](O)[C@H](O)[C@@H]1O</smiles>

Valiolamine (296)<smiles>OCC1=C[C@@H](N[C@H]2C[C@H](CO)[C@@H](O)[C@H](O[C@@H]3O[C@H](CO)[C@@H](O)[C@H](O)[C@H]3O)[C@H]2O)[C@H](O)[C@@H](O)[C@@H]1O</smiles><smiles>N[C@H]1C[C@H](CO)[C@@H](O)[C@H](O)[C@H]1O</smiles>

Validamine (299)

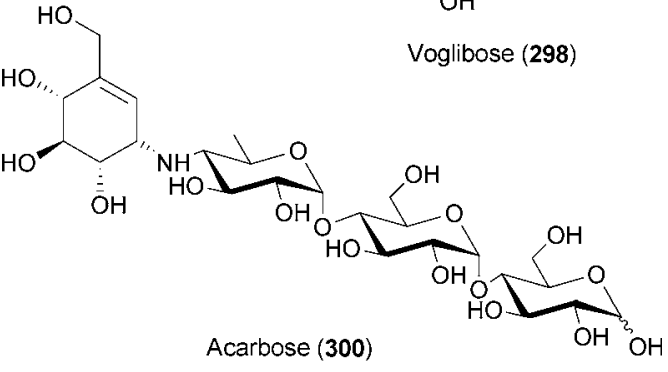

Fig. 17 Examples of naturally occurring carbasugar $\alpha$-glucosidase inhibitors and the antibiotic validamycin. 
second-generation catalyst to yield cyclohexenes $\mathbf{3 0 5} \mathbf{a}$ and $\mathbf{3 0 5} \mathbf{b}$ in a $2.4: 1$ ratio. After separation, 305a underwent substitution with DPPA- $\mathrm{NaN}_{3}$ to form 306, which through stepwise reduction, debenzylation and peracetylation was converted to valienamine pentaacetate (307) with an overall yield of $14.5 \%$.

The use of a D-glucose-derived starting material and ring-closing metathesis also features prominently in Cumpstey's formal synthesis of valienamine (295), although in this case the use of ethanethiol and mercury salts is avoided by the direct addition of vinylmagnesium bromide to glucose derivative 308 (Scheme 46). ${ }^{155}$ The mixture of 1,5-diols generated in this reaction were separated, the major product 309b selectively monoalkylated with 3,4-dimethoxybenzyl chloride and the product transformed to $\mathbf{3 1 1}$ and byproduct $\mathbf{3 1 0}$, which arises as a result of benzylation of the non-allylic hydroxyl group of 309b. Wittig methylenation of $\mathbf{3 1 1}$ furnished 1,7-diene 312, which underwent RCM to form 313, after removal of the pivalate ester. Since Fukase has previously converted $\mathbf{3 1 3}$ to valienamine (295) via a three-step sequence, preparation of 313 represents a formal synthesis of this natural product. ${ }^{156}$

Employing $C_{2}$-symmetric L-tartrate derivative 314, Yan and co-workers have developed a route to $(+)$-valienamine pentaacetate (307) and several other important $\mathrm{C}_{7} \mathrm{~N}$ aminocyclitols that is notable for both its brevity and the use of a [3,3]-sigmatropic rearrangement to control introduction of the $\mathrm{C} 1$ amine group (Scheme 47). ${ }^{157}$ The cyclohexenyl ring of $\mathbf{3 0 7}$ was established in
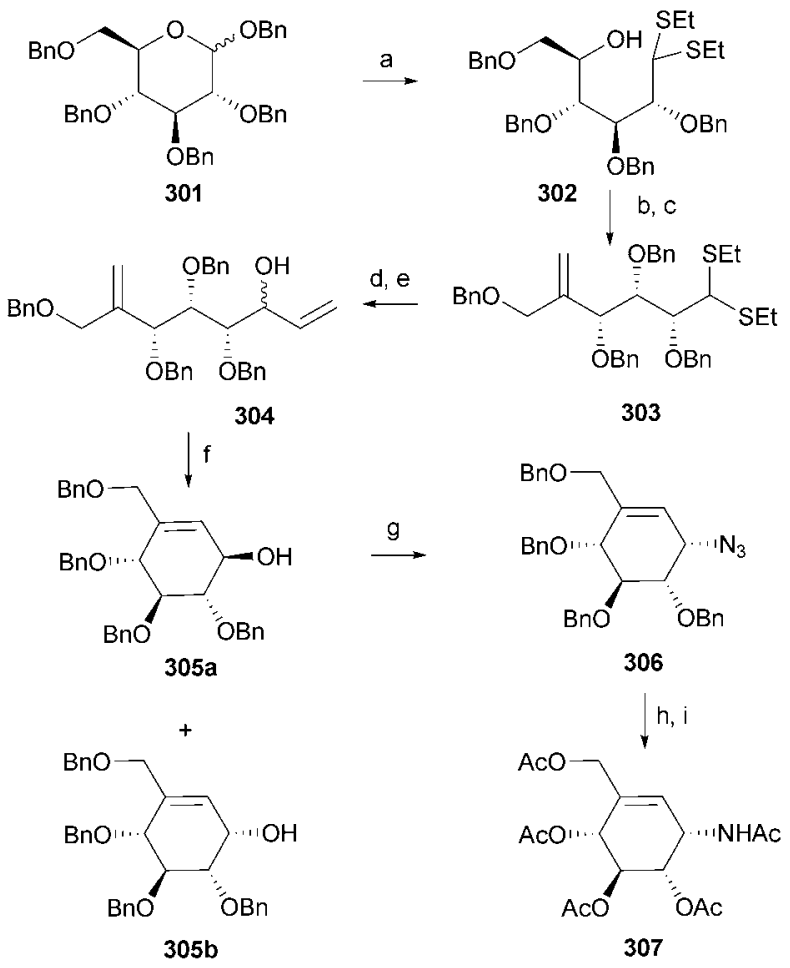

Scheme 45 Jeon and Kim's synthesis of valienamine pentaacetate. Reagents and conditions: (a) EtSH, TFA, rt, 12 h, 77\%; (b) DMSO, $\mathrm{Ac}_{2} \mathrm{O}$, rt, 12 h, $94 \%$; (c) $\mathrm{Ph}_{3} \mathrm{PCH}_{3} \mathrm{Br}, t$ - $\mathrm{BuOH}, 88 \%$; (d) $\mathrm{HgCl}_{2}, \mathrm{HgO}, \mathrm{CH}_{3} \mathrm{CN}-$ $\mathrm{H}_{2} \mathrm{O}, 80-90{ }^{\circ} \mathrm{C}$; (e) vinylmagnesium bromide, THF, $-78{ }^{\circ} \mathrm{C}, 79 \%(2$ steps); (f) Grubbs' 2nd-generation catalyst, $\mathrm{CH}_{2} \mathrm{Cl}_{2}(0.05 \mathrm{M})$, reflux, 305a (61\%), 305b (25\%); (g) DPPA, DBU, $\mathrm{PhCH}_{3}, 0{ }^{\circ} \mathrm{C}$; $\mathrm{NaN}_{3}, 40{ }^{\circ} \mathrm{C}, 83 \%(2$ steps); (h) $\mathrm{Ph}_{3} \mathrm{P}, \mathrm{NH}_{4} \mathrm{OH}$, pyridine, rt, $80 \%$; (i) $\mathrm{Na} / \mathrm{NH}_{3}, \mathrm{THF},-78{ }^{\circ} \mathrm{C}$; (j) $\mathrm{Ac}_{2} \mathrm{O}$, pyridine, $71 \%$ (two steps). this case through reduction of $\mathbf{3 1 4}$, double diastereoselective addition of divinylzinc to the dialdehyde and RCM metathesis of the resulting 1,7-diene to form 316. Base-mediated monotriflation of this diol now generated epoxide 317, which upon treatment with azide underwent ring opening at the allylic position to generate 318a. When conducted at $90^{\circ} \mathrm{C}$, 318a underwent rearrangement to 1,4 -azido alcohol $\mathbf{3 1 8 b}$, in which the azide substituent is in a pseudoequatorial rather than axial orientation. After introduction of the C4 hydroxymethyl group via formation and Baylis-Hillman reaction of 319, chelation-controlled reduction of $\mathbf{3 2 0}$ provided $\mathbf{3 2 1}$, which was converted to $\mathbf{3 0 7}$, the pentaacetate derivative of valienamine, by azide reduction, deacetalization and peracetylation.

In contrast to the two other syntheses of valienamine (295) reported during the review period, Krishna's recent preparation of this natural product and its $\mathrm{C} 4$ epimer does not involve cyclohexene formation via $\mathrm{RCM}$, but rather a ring-closing enyne metathesis reaction (RCEYM) (Scheme 48). ${ }^{158}$ The substrate for this cyclization (325) was prepared from L-serine derivative 322 through a nine-step sequence featuring Sharpless asymmetric dihydroxylation and Carriera asymmetric alkynylation. In the presence of Grubbs' second-generation catalyst and ethylene, 325 underwent cyclization to form a 1-vinylcyclohex-1-ene, which upon oxidative cleavage of the 1,4-diene and enal reduction provided 326. Global deprotection, accomplished by treatment of 326 with TFA in $\mathrm{CH}_{2} \mathrm{Cl}_{2}$, then provided valienamine, which was isolated as its pentaacetate derivative $\mathbf{3 0 7}$.

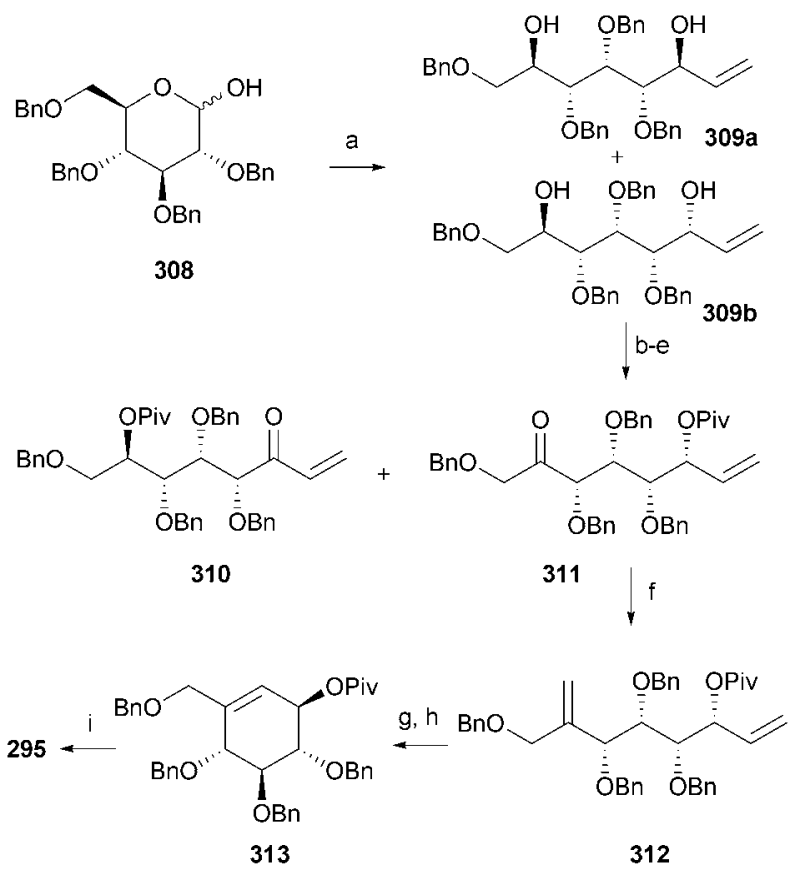

Scheme 46 Cumpstey's synthesis of valienamine. Reagents and conditions: (a) vinylmagnesium bromide, THF, $0{ }^{\circ} \mathrm{C}, 309 \mathrm{a}(29 \%)$, 309b (65\%); (b) 3,4-dimethoxybenzyl chloride, DMF, $\mathrm{NaH}, 0{ }^{\circ} \mathrm{C}, 57 \%$, regioselection = 10 : 1; (c) PivCl, pyridine, DMAP, 93\%; (d) $\mathrm{CAN}, \mathrm{MeCN}-\mathrm{H}_{2} \mathrm{O}, 0^{\circ} \mathrm{C} \rightarrow$ rt, 74\%; (e) $\mathrm{COCl}_{2}$, DMSO, Et ${ }_{3} \mathrm{~N}, \mathrm{CH}_{2} \mathrm{Cl}_{2},-60{ }^{\circ} \mathrm{C}, 310$ (7\%), 311 (81\%); (f) $\mathrm{PPh}_{3} \mathrm{CH}_{3} \mathrm{Br}$, THF, NaHMDS $-78^{\circ} \mathrm{C}, 63 \%$; (g) Grubbs' 2nd-generation catalyst, $\mathrm{PhCH}_{3}, 60{ }^{\circ} \mathrm{C}, 65 \%$; (h) $\mathrm{NaOMe}, \mathrm{MeOH}, 40{ }^{\circ} \mathrm{C}, 99 \%$; (i) 3 steps described in ref. 156. 
<smiles>COC(=O)[C@H]1OC(C)(C)O[C@H]1C(=O)OC</smiles><smiles>C=C[C@H](O)[C@H]1OC(C)(C)O[C@@H]1[C@H](O)C=C</smiles>
$\mathrm{HO}$,<smiles>CC1(C)O[C@H]2[C@H](O)C=C[C@H](O)[C@H]2O1</smiles><smiles>CC1CCCC2OC(Br)C(C)(C)OC12</smiles>

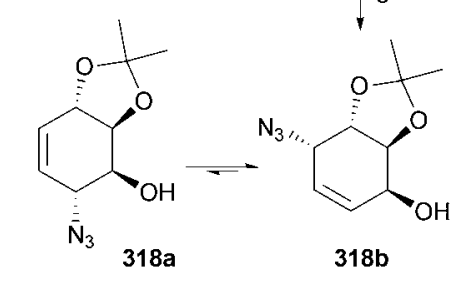

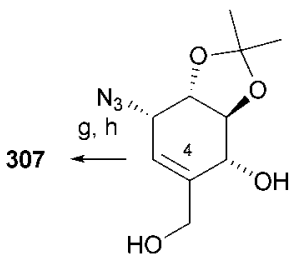

321
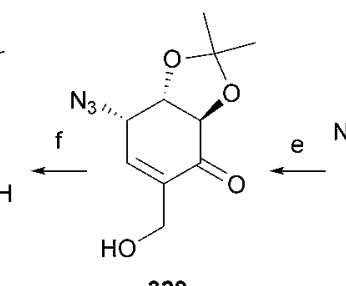

320
$318 \mathrm{~b}$

d<smiles>CC(C)(C)O</smiles><smiles>COC1C[CH]C=CC1=O</smiles>

319

Scheme 47 Yan's synthesis of valienamine pentaacetate. Reagents and conditions: (a) DIBAL-H, $-78{ }^{\circ} \mathrm{C}$; then $\mathrm{ZnCl}_{2}$, vinylmagnesium bromide, $83 \%$; (b) Grubbs' 2nd-generation catalyst, $\mathrm{CH}_{2} \mathrm{Cl}_{2}$, reflux, $2 \mathrm{~h}, 70 \%$; (c) $\mathrm{PhNTf}_{2}, \mathrm{NaH}, \mathrm{DMF}, 2{ }^{\circ} \mathrm{C}, 15 \mathrm{~min} ; \mathrm{NaN}_{3}, \mathrm{EtOH}-\mathrm{H}_{2} \mathrm{O}, 90{ }^{\circ} \mathrm{C}, 12 \mathrm{~h}$, $70 \%$; (d) Dess-Martin periodinane, $\mathrm{CH}_{2} \mathrm{Cl}_{2}, 25^{\circ} \mathrm{C}, 3 \mathrm{~h}, 96 \%$; (e) $\mathrm{HCHO}$, $\mathrm{NaHCO}_{3}$, THF- $\mathrm{H}_{2} \mathrm{O}$, imidazole, $25{ }^{\circ} \mathrm{C}, 18 \mathrm{~h}, 80 \%$; (f) $\mathrm{NaBH}_{4}, \mathrm{CeCl}_{3}-$ $\mathrm{MeOH},-78{ }^{\circ} \mathrm{C}, 20 \mathrm{~min}, 80 \%$; (g) $\mathrm{LiAlH}_{4}, \mathrm{Et}_{2} \mathrm{O}, 0{ }^{\circ} \mathrm{C}, 1 \mathrm{~h}$; then $\mathrm{AcOH}-$ $\mathrm{H}_{2} \mathrm{O}, 0 \rightarrow 50{ }^{\circ} \mathrm{C}$; (h) $\mathrm{Ac}_{2} \mathrm{O}$, pyridine, $50 \%$ (2 steps).

\subsection{Valiolamine and voglibose}

Voglibose (298, Basen $^{\circledR}$ ), an $N$-alkylated glycerol derivative of valiolamine (296), is a potent inhibitor of intestinal $\alpha$-glucosidase, which delays the absorption of carbohydrates and thereby prevents hyperglycemia and the host of disorders associated with this condition. ${ }^{159}$ This compound is currently employed in Japan, China and Korea for the management of type II diabetes. ${ }^{160}$ During the review period, Shing and Cheng reported a synthesis of valiolamine, validoxylamine $G$ and a formal synthesis of voglibose, which utilizes a stereoselective intramolecular aldol reaction to generate the common carbocyclic skeleton of these targets (Scheme 49). ${ }^{161}$

The key step in this work involves the highly stereoselective KHMDS-mediated cyclization of 1,5-diketone 327 (prepared in 6 steps and 30\% yield from D-glucose) to form 328 (Scheme 49). Notably, the stereochemical outcome of this transformation was found to be remarkably sensitive to the identity of the base employed - L-proline led to the formation of the C5 epimer of 328, while D-proline generated the C4 epimer. From 328, reductive amination of the corresponding oxime generated valiolamine (296) with excellent stereocontrol, after removal of the acetal protecting groups. Since reductive amination of 296 with 1,3-dihydroxyacetone in the presence of sodium cyanoborohydride leads to the formation of voglibose (298), this work represents a formal synthesis of this medicinally important target molecule. ${ }^{159}$ Shing and co-workers have also utilized the
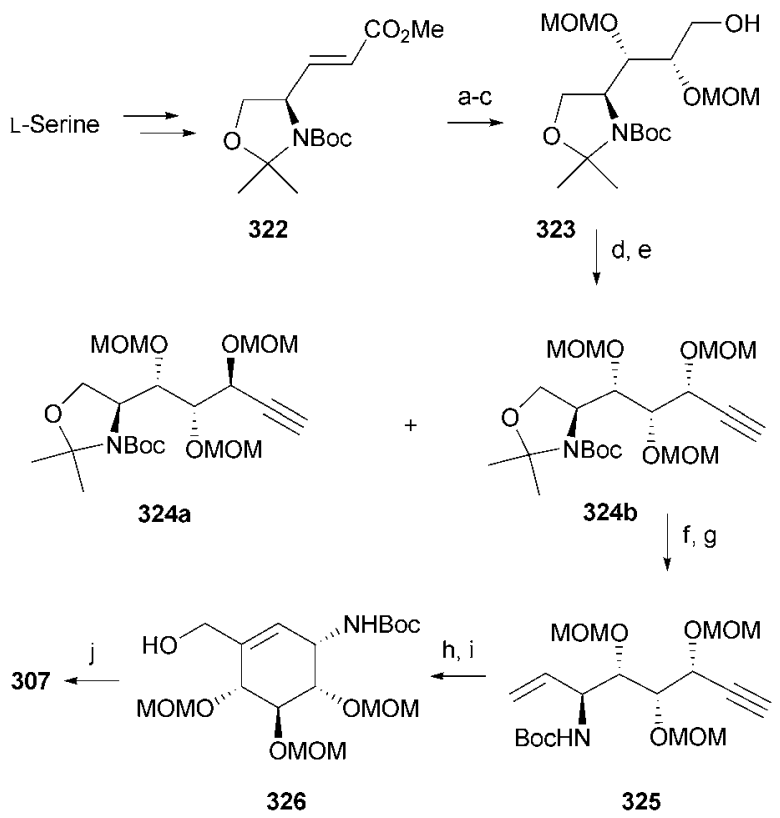

Scheme 48 Krishna's synthesis of valienamine pentaacetate. Reagents and conditions: (a) AD-mix $\alpha, \mathrm{OsO}_{4}, \mathrm{MeSO}_{2} \mathrm{NH}_{2}, t$ - $\mathrm{BuOH}-\mathrm{H}_{2} \mathrm{O}, 0{ }^{\circ} \mathrm{C}, 16$ h, 84\%; (b) $\mathrm{MOMCl}$, DIPEA, $\mathrm{CH}_{2} \mathrm{Cl}_{2}, 0^{\circ} \mathrm{C} \rightarrow \mathrm{rt}, 17 \mathrm{~h}, 93 \%$, (c) $\mathrm{LiAlH}_{4}$, $\mathrm{THF}, 0{ }^{\circ} \mathrm{C} \rightarrow \mathrm{rt}, 1 \mathrm{~h}, 75 \%$; (d) $\mathrm{COCl}_{2}$, DMSO, $\mathrm{Et}_{3} \mathrm{~N},-78^{\circ} \mathrm{C}$; then TMSacetylene, $n$-BuLi, $-78^{\circ} \mathrm{C}, 4 \mathrm{~h}$; $\mathrm{Zn}(\mathrm{OTf})_{2},(-)-N$-methylephedrine, $\mathrm{Et}_{3} \mathrm{~N}$, $\mathrm{PhCH}_{3}, 86 \%$, dr $=98: 1$; (e) $\mathrm{MOMCl}$, DIPEA, $\mathrm{CH}_{2} \mathrm{Cl}_{2}, 0{ }^{\circ} \mathrm{C} \rightarrow \mathrm{rt}, 8 \mathrm{~h}$; (f) $\mathrm{CuCl}_{2} \cdot \mathrm{H}_{2} \mathrm{O}, \mathrm{MeCN}, 0{ }^{\circ} \mathrm{C}, 0.5 \mathrm{~h}, 92 \%$; (g) Swern oxidation; then $\mathrm{Ph}_{3} \mathrm{PCH}_{3} \mathrm{I}, t$-BuOK, THF, $0{ }^{\circ} \mathrm{C}, 8 \mathrm{~h}, 64 \%$; (h) Grubbs' 2nd-generation catalyst (10 mol\%), $\mathrm{PhCH}_{3}, 110{ }^{\circ} \mathrm{C}, 12 \mathrm{~h}, 92 \%$; (i) $\mathrm{OsO}_{4}, \mathrm{NMO}$ (0.5 eq), acetone- $\mathrm{H}_{2} \mathrm{O}(4: 1), 5 \mathrm{~h} ; \mathrm{NaIO}_{4}, \mathrm{MeOH}-\mathrm{H}_{2} \mathrm{O}(9: 1), 0{ }^{\circ} \mathrm{C}, 5 \mathrm{~min}, 62 \%(3$ steps); (j) TFA, $\mathrm{CH}_{2} \mathrm{Cl}_{2}, 0{ }^{\circ} \mathrm{C}, 4 \mathrm{~h}$; (k) $\mathrm{Ac}_{2} \mathrm{O}$, pyridine, DMAP, $\mathrm{CH}_{2} \mathrm{Cl}_{2}$, rt, $14 \mathrm{~h}, 68 \%$ (two steps).

synthetic strategy outlined in Scheme 49 for the preparation of pseudoacarviosin, a pseudo- $1,4^{\prime}$ - $N$-linked disaccharide with potent anti $\alpha$-glucosidase (sucrase and glucoamylase) activity. ${ }^{162}$

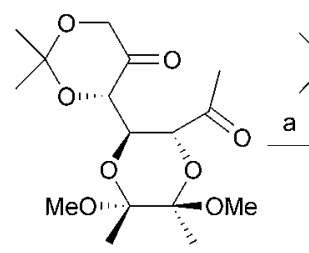

327<smiles>OCC(CO)N[C@@H]1C[C@](O)(CO)[C@@H](O)[C@H](O)[C@H]1O</smiles>

Voglibose (298)

328
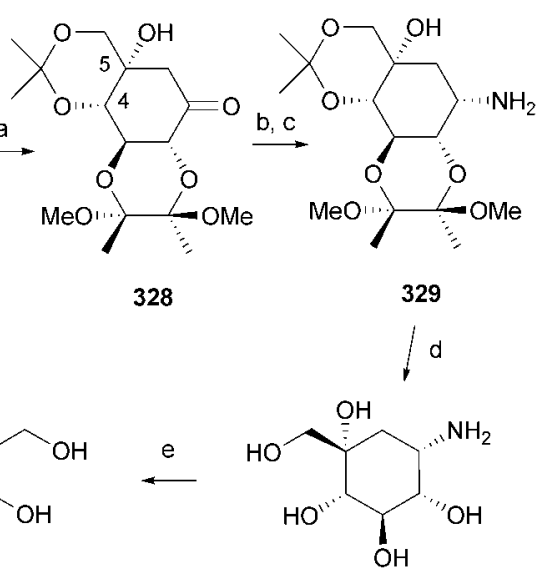

Valiolamine (296)
Scheme 49 Shing's synthesis of valiolamine and formal synthesis of voglibose. Reagents and conditions: (a) KHMDS (1 eq), $\mathrm{PhCH}_{3},-78^{\circ} \mathrm{C}$, $75 \%$; (b) $\mathrm{NH}_{2} \mathrm{OH} \cdot \mathrm{HCl}, \mathrm{NaHCO}_{3}, \mathrm{MeOH}$; (c) $\mathrm{H}_{2}$, RANEY ${ }^{\circledR} \mathrm{Ni}, \mathrm{EtOH}$, $\mathrm{Et}_{3} \mathrm{~N}, 85 \%$ (2 steps); (d) TFA, $\mathrm{H}_{2} \mathrm{O}, \mathrm{CH}_{2} \mathrm{Cl}_{2}, 88 \%$; (e) 1,3-dihydroxyacetone, $\mathrm{Na}(\mathrm{CN}) \mathrm{BH}_{3}, 2 \mathrm{M} \mathrm{HCl}-\mathrm{DMF}, 50-60{ }^{\circ} \mathrm{C}, 15 \mathrm{~h}, 73 \%$ (ref. 159). 


\section{Marine organosulfates}

While the overwhelming majority of naturally occurring glucosidase inhibitors have to date been isolated from terrestrial plant sources, during the last decade there has been increasing interest in the discovery of inhibitors from marine organisms. ${ }^{163}$ Of particular note in this regard has been the work of Fusetani and collaborators who, while screening Japanese marine invertebrates for drug candidates, ${ }^{164}$ discovered a number of novel $\alpha$-glucosidase inhibitors which bear scant resemblance to iminosugars (Fig. 18). ${ }^{165}$ Members of this group, which include the penarolides (330 and 331) ${ }^{166}$ penasulfate A (332) ${ }^{167}$ and the schulzeine family (333-336), ${ }^{168}$ are structurally related in that they each comprise an alkaloid or amino acid residue coupled with an $O$-sulfated longchain fatty acid through an amide group.

\subsection{Penoralide sulfates}

Isolated from a marine sponge Penares sp. collected in the waters off Hachijo-jima Island, penarolide sulfate $A_{1}$ (330) and $A_{2}$ (331) are structurally unique 30 - and 31-membered macrolides which encompass a trisulfated, lipophilic chain encircled by a proline residue. ${ }^{166}$ These compounds inhibit $\alpha$-glucosidase with $\mathrm{IC}_{50}$ values of 1.2 and $1.5 \mu \mathrm{g} / \mathrm{mL}$ making them approximately $30-40$ times more active than 1-deoxynojirimycin (1). In common with a number of other sulfated natural products, ${ }^{169}$ the penarolides also display anti-thrombin activity.

To date, a single total synthesis of the penarolides has been reported, by Mohapatra and co-workers, who employed an intramolecular Sonogoshira coupling reaction to establish the 30-atom macrolide ring of penarolide $A_{1}$ (330) (Schemes $50-53) .{ }^{170}$ In this highly convergent approach, synthesis of the C1-C18 carboxylic acid subunit $\mathbf{3 4 2}$ commenced from dodecane1,12-diol (337), which was converted via a three-step sequence to 338 (Scheme 50). Sharpless asymmetric dihydroxylation of this $E, E$-dienoate proceeded with complete regiocontrol to provide 339, which was then converted to $\mathbf{3 4 0}$ through a succession of diol protection, reduction and Sharpless asymmetric epoxidation. After conversion of $\mathbf{3 4 0}$ to the corresponding alkyl chloride, treatment with $n$-BuLi generated propargylic alcohol 341. Oxidative debenzylation followed by stepwise oxidation of the primary alcohol then generated $\mathrm{C}_{18}$ acid $\mathbf{3 4 2}$.

The C19-C30-proline subunit $\mathbf{3 4 8}$ was prepared from known aldehyde $\mathbf{3 4 3}$, which was converted to $\mathbf{3 4 4}$ in a single step via a Corey-Chakovsky reaction (Scheme 51). Hydrolytic kinetic resolution of this epoxide, using $(R, R)$-salen-Co(III)OAc, then provided 346 which through alkylative ring opening and coupling with $N$-Boc-L-proline was converted to 348 . Introduction of the (E)-vinyl iodide moiety necessary for macrocyclization was accomplished by debenzylation, oxidation and Takai olefination which, after removal of the Boc group, furnished fragment 349.

With both subunits of penarolide $\mathrm{A}_{1}$ assembled, carbodiimidemediated coupling of $\mathbf{3 4 9}$ and $\mathbf{3 4 1}$ proceeded in high yield to provide ester 350, which underwent intramolecular Sonogashira cross-coupling to generate macrocycle $\mathbf{3 5 1}$ in 35\% yield (Scheme 52). Reduction of the enyne group, through hydrogenation over RANEY ${ }^{\circledR} \mathrm{Ni}$, and global deprotection under acidic conditions now provided triol 352 which, upon treatment with pyridine-
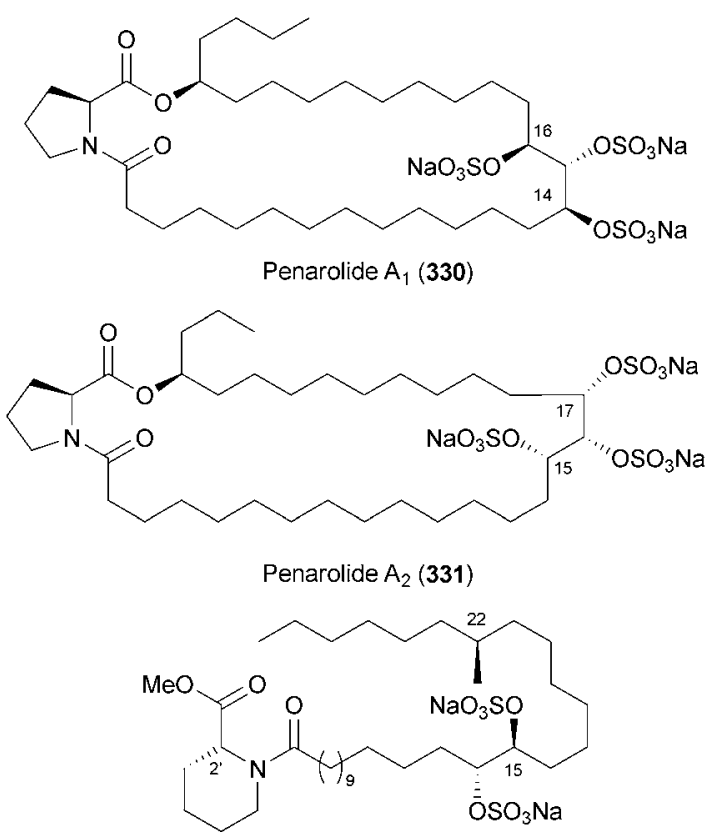

Penasulfate A (332)

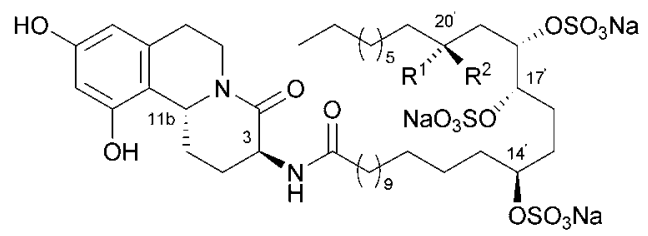

(+)-Schulzeine A (proposed, 333, $\mathrm{R}^{1}=\mathrm{Me}, \mathrm{R}^{2}=\mathrm{H}$ )

(+)-Schulzeine A (revised, 334, $\mathrm{R}^{1}=\mathrm{H}, \mathrm{R}^{2}=\mathrm{Me}$ )

(+)-Schulzeine C (335, $\left.\mathrm{R}^{1}=\mathrm{H}, \mathrm{R}^{2}=\mathrm{H}\right)$

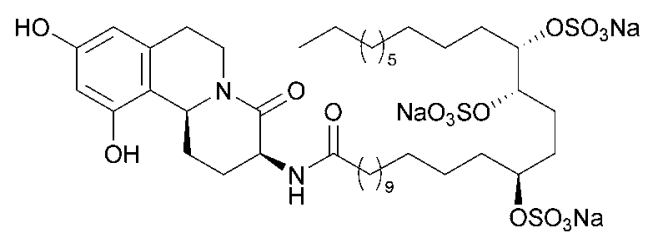

(-)-Schulzeine B (336)

Fig. 18 Structure of organosulfate $\alpha$-glucosidase inhibitors isolated from marine invertebrates.

sulfur trioxide complex, was converted to penarolide $\mathrm{A}_{1}$ (330). The importance of the organosulfate groups to the biological activity of the penarolides and related natural products is underscored by Mohapatra's finding that while also an $\alpha$-glucosidase inhibitor, compound $\mathbf{3 5 2}$ is significantly less active than the natural product itself.

\subsection{Schulzeines}

The schulzeines (333-336), isolated by Fusetani and co-workers from extracts of the marine sponge Penares schulzei, not only represent a new class of marine alkaloids, but also display potent $\alpha$-glucosidase-inhibitory activity $\left(\mathrm{IC}_{50}=48-170 \mathrm{nM}\right)$ (Fig. 18) ${ }^{168}$ The structure of each of the three members of this family was 


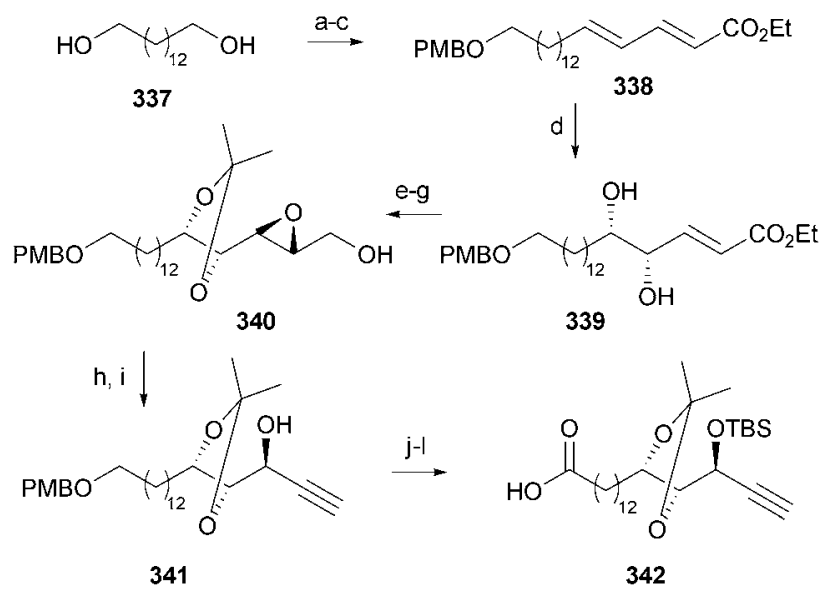

Scheme 50 Mohapatra's total synthesis of penarolide $A_{1}$ : Preparation of the $\mathrm{C} 1-\mathrm{C} 18$ subunit. Reagents and conditions: (a) $\mathrm{PMBBr}, \mathrm{NaH}$, THFDMF, 90\%; (b) IBX, DMSO, 95\%; (c) ethyl 4-(dimethylphosphono)crotonate, LiHMDS, THF, $-78{ }^{\circ} \mathrm{C}, 83 \%$; (d) AD-mix $\alpha, \mathrm{MeSO}_{2} \mathrm{NH}_{2}$, $t$ - $\mathrm{BuOH}, \mathrm{H}_{2} \mathrm{O}, 70 \%$, ee $=98.4 \%$; (e) 2,2-dimethoxypropane, $\mathrm{TsOH}$, $\mathrm{CH}_{2} \mathrm{Cl}_{2}, 96 \%$; (f) DIBAL-H, $\mathrm{CH}_{2} \mathrm{Cl}_{2},-78{ }^{\circ} \mathrm{C}, 85 \%$; (g) D-(-)-DIPT, $\mathrm{Ti}(\mathrm{O}-i \text {-Pr })_{4}, t$-BuOOH, $4 \AA$ A $\mathrm{MS}, \mathrm{CH}_{2} \mathrm{Cl}_{2},-20{ }^{\circ} \mathrm{C}, 67 \%, \mathrm{dr}>95: 5$; (h) $\mathrm{Ph}_{3} \mathrm{P}, \mathrm{CCl}_{4}, \mathrm{NaHCO}_{3}$, reflux, $90 \%$; (i) $n$ - BuLi (3 eq), THF, $-30{ }^{\circ} \mathrm{C}, 72 \%$; (j) TBSCl, imidazole, $\mathrm{CH}_{2} \mathrm{Cl}_{2}, 94 \%$; (k) DDQ, $\mathrm{CH}_{2} \mathrm{Cl}_{2}$, buffer ( $\mathrm{pH}=7$ ), $76 \%$; (1) IBX, DMSO, $95 \%$; $\mathrm{NaClO}_{2}, \mathrm{NaH}_{2} \mathrm{PO}_{4} \cdot \mathrm{H}_{2} \mathrm{O}$, 2-methyl-2-butene, $t$ - $\mathrm{BuOH}, \mathrm{H}_{2} \mathrm{O}, 88 \%$.

elucidated through a combination of spectral analysis and chemical degradation, while absolute configuration was determined by modified Mosher analysis of the fragments obtained upon acidic hydrolysis of the lipid side chains. Although total synthesis has subsequently confirmed the assignments originally made for

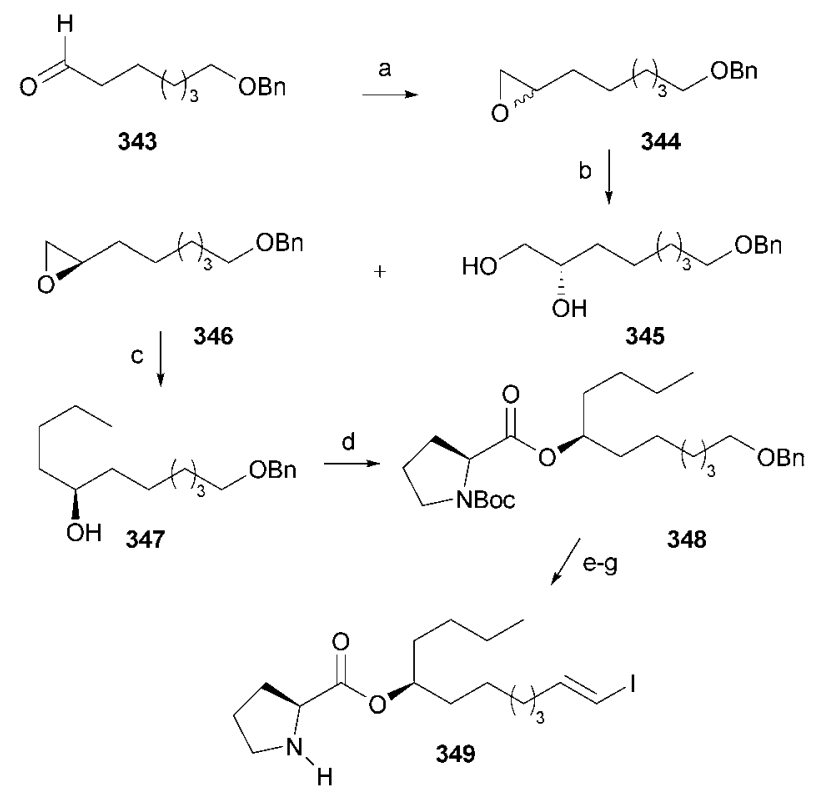

Scheme 51 Mohapatra's total synthesis of penarolide $A_{1}$ : Preparation of the C19-C30-proline subunit. Reagents and conditions: (a) $\mathrm{Me}_{3} \mathrm{SO}^{+} \mathrm{I}^{-}$, $\mathrm{NaH}$, DMSO, 84\%; (b) ( $R, R)$-salen-Co(III)OAc (0.5 mol\%), $\mathrm{H}_{2} \mathrm{O}, 344$ (47\%), ee =98.8\%; (c) $\mathrm{PrMgBr}, \mathrm{CuCN}, \mathrm{THF}, 78 \%$; (d) $N$-Boc-L-proline, EDC, DMAP, $\mathrm{CH}_{2} \mathrm{Cl}_{2}, 95 \%$; (e) $\mathrm{H}_{2}$, Pd/C, EtOAc, $87 \%$; (f) IBX, DMSO, 90\%; (g) $\mathrm{CrCl}_{2}, \mathrm{CHI}_{3}$, THF, 90\%; (h) $4 \mathrm{M} \mathrm{HCl-EtOAc,} \mathrm{81 \% .}$

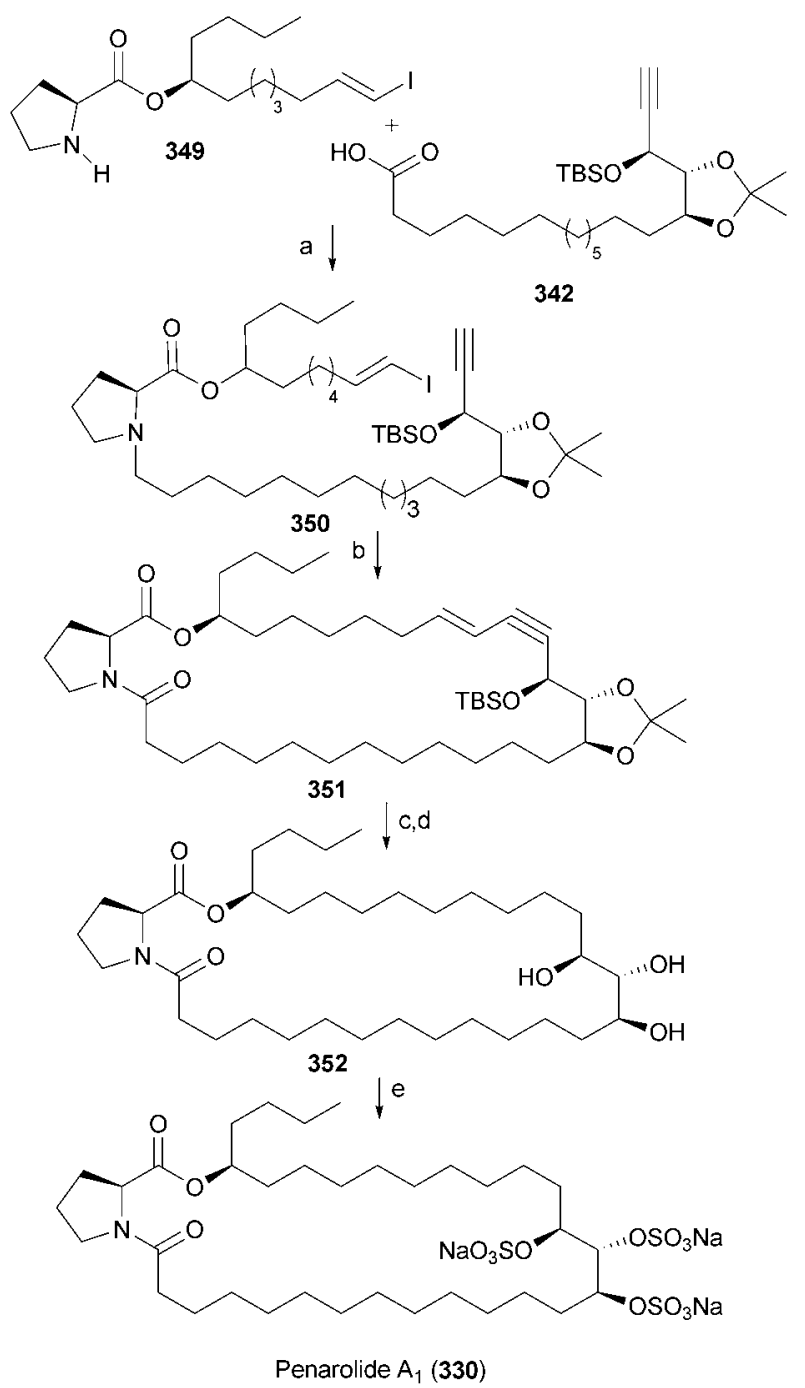

Scheme 52 Mohapatra's total synthesis of penarolide $\mathrm{A}_{1}$. Reagents and conditions: (a) EDC, $\mathrm{HOBt}, \mathrm{CH}_{2} \mathrm{Cl}_{2}, 96 \%$; (b) $\mathrm{Pd}\left(\mathrm{PPh}_{3}\right)_{4}, \mathrm{CuI}, \mathrm{Et}_{2} \mathrm{NH}$, $35 \%$; (c) $\mathrm{H}_{2}$, RANEY ${ }^{\circledR}{ }^{\circledR} \mathrm{Ni}, \mathrm{EtOH}, 92 \%$; (d) $\mathrm{TsOH}, \mathrm{MeOH}, 82 \%$; (e) $\mathrm{SO}_{3} \cdot$ pyr, DMF, rt, $36 \mathrm{~h} ; \mathrm{H}_{2} \mathrm{O}, 0{ }^{\circ} \mathrm{C}, 30 \mathrm{~min} ; \mathrm{NaHCO}_{3}, 0{ }^{\circ} \mathrm{C}, 84 \%$.

schulzeine B (336) and C (335), Wardrop and Bowen have demonstrated that the stereochemical assignment made for the $\mathrm{C} 20^{\prime}$ stereocenter for schulzeine A (334) should be revised (vide infra). In light of their bioactivity and structural novelty, the schulzeines have garnered significant interest from the synthetic community, with three total syntheses of various members of this family having been published since their isolation in 2004.

First to report a study directed towards the synthesis of the schulzeines, Kuntiyong and co-workers have developed a short route to the cis and trans-3-aminobenzo[a]quinolizidine ring systems common to this group (Scheme 53). ${ }^{171}$ The key step in this endeavour involves the Pictet-Spengler reaction of $\alpha$-hydroxy- $\delta$ lactam 356, which was assembled from L-glutamic acid derivative 352 and 2-(3,5-dimethoxyphenyl)ethylamine (353). While Lewisacid-mediated ring closure of $\mathbf{3 5 6}$ led to the formation of tricycles cis-357 and trans-357 in excellent yield, the diastereoselectivity of this process proved to be disappointingly low $(\mathrm{dr}=2.2: 1)$. Nonetheless, chromatographic separation of these $\mathrm{C} 11 \mathrm{~b}$ epimers 


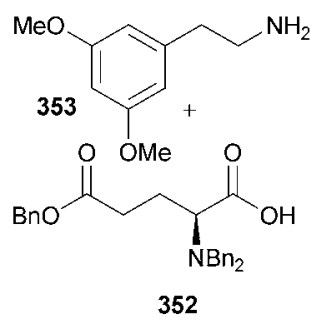

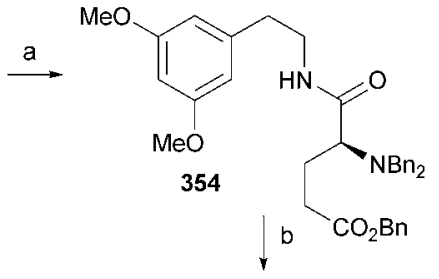

$\mathrm{MeO}$

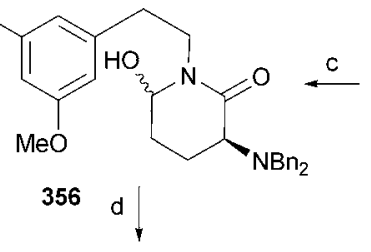

$\mathrm{MeO}$

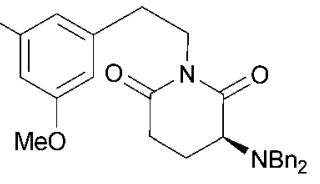

355

$\mathrm{MeO}$

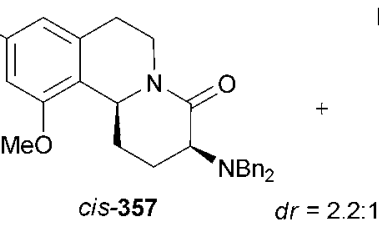

$\mathrm{MeO}$

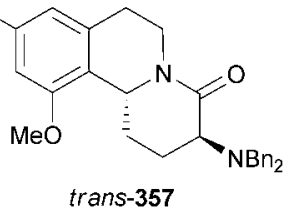

$\mathrm{MeO}$
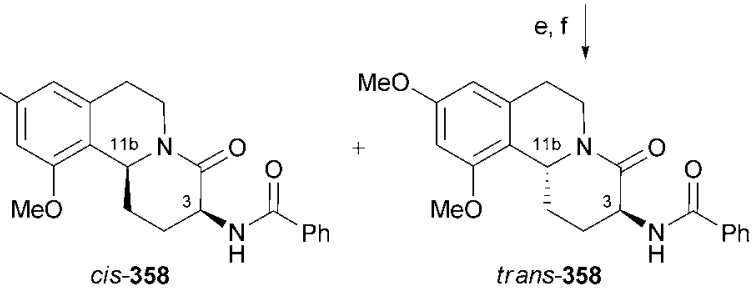

Scheme 53 Kuntiyong's synthesis of the schulzeine benzo $[a]$ quinolizidine subunits. Reagents and conditions: (a) DCC, DMAP, $\mathrm{CH}_{2} \mathrm{Cl}_{2}, 63 \%$; (b) $\mathrm{LiAlH}_{4}, \mathrm{THF}, 53 \%$; (c) DIBAL-H, $\mathrm{PhCH}_{3},-78{ }^{\circ} \mathrm{C}, 75 \%$; (d) TMSOTf, $\mathrm{CH}_{2} \mathrm{Cl}_{2}, 0{ }^{\circ} \mathrm{C}, 95 \%, \mathrm{dr}=2.2: 1$; (e) $\mathrm{H}_{2}, \mathrm{Pd} / \mathrm{C}, \mathrm{MeOH}, \mathrm{rt}$; (f) $\mathrm{BzCl}$, pyridine, $\mathrm{CH}_{2} \mathrm{Cl}_{2}, 0{ }^{\circ} \mathrm{C}, 94 \%$ (2 steps).

was accomplished after de- $O$-benzylation and conversion to the corresponding benzamide derivatives $\mathbf{3 5 8}$.

Employing a convergent strategy, Gurjar and co-workers were the first to complete the total synthesis of schulzeine B (336) and C (335) (Schemes 54-56). ${ }^{172}$ In this case, a Bischler-Napieralski rather than a Pictet-Spengler reaction was utilized in the construction of the tetrahydroisoquinoline "head" subunit. Reaction of L-glutamate derivative 361 with $\mathrm{POCl}_{3}$ generated 3,4-dihydroisoquinoline $\mathbf{3 6 2}$ which, upon treatment with $\mathrm{NaCNBH}_{3}$ in the presence of acetic acid, underwent non-selective reduction to form $\mathrm{C} 11 \mathrm{a}$ epimers $c i s-363$ and trans-363. While these diastereomers proved to be chromatographically separable, the lack of orthogonality between the $\mathrm{Cbz}$ and $O$-benzyl groups and the need to access protected amines cis and trans-364 now necessitated exchange of the carbamate group. For each isomer, this was accomplished by hydrogenolysis in the presence of $\mathrm{Boc}_{2} \mathrm{O}$, bis- $O$-benzylation of the free catechol and solvolysis of the $N$-Boc group.

The unbranched $\mathrm{C}_{28}$ side chain common to both schulzeine $\mathrm{B}$ and $\mathrm{C}$ (but not $\mathrm{A}$ ) was assembled from 1,12-dodecanedicarboxylic acid (365) and undecan-1-al (366), which were respectively converted to phosphonate 367 and aldehyde 368 (Scheme 55). Horner-Wittig-Emmons reaction of these fragments then generated $E$-enone 369. Having established the absolute configuration of the $\mathrm{C} 17^{\prime}$ and $\mathrm{C} 18^{\prime}$ stereogenic centers through Sharpless asymmetric dihydroxylation, the remaining chiral center at $\mathrm{C}^{\prime} 4^{\prime}$ was installed through stoichiometric reduction with $(S)$ (-)-BINAL-H. After separation of the minor diastereomer $(\mathrm{dr}=$ $11: 1$ ), allylic alcohol $\mathbf{3 7 0}$ was converted to the saturated $\mathrm{C}_{28}$ carboxylic acid 371 through a sequence of $O$-protection, hydrogenolysis/hydrogenation and oxidation.

Gurjar's route to schulzeine B (336) was completed through carbodiimide-mediated coupling of carboxylic acid $\mathbf{3 7 1}$ and amine cis-364 to provide 372 (Scheme 56). After simultaneous removal of the acetonide and MOM protecting groups with trimethylsilyl iodide, the resulting triol was persulfated by treatment with $\mathrm{SO}_{3}$. pyridine complex in DMF and the benzyl ethers removed to provide schulzeine B (337) in high yield. Following the same sequence of reactions, (+)-schulzeine $\mathrm{C}(\mathbf{3 3 5})$ was also prepared from trans-364. In both cases, Gurjar found that the spectral and analytic data for these synthetic products match closely that reported for the natural products themselves.

In 2009, Romo and Liu reported the second enantioselective synthesis of schulzeine B (336) and C (335) (Schemes 57 and $58),{ }^{173}$ their strategy in this case being notably different from other routes to these targets in not employing L-glutamate for construction of the tetrahydroisoquinoline subunit. In this
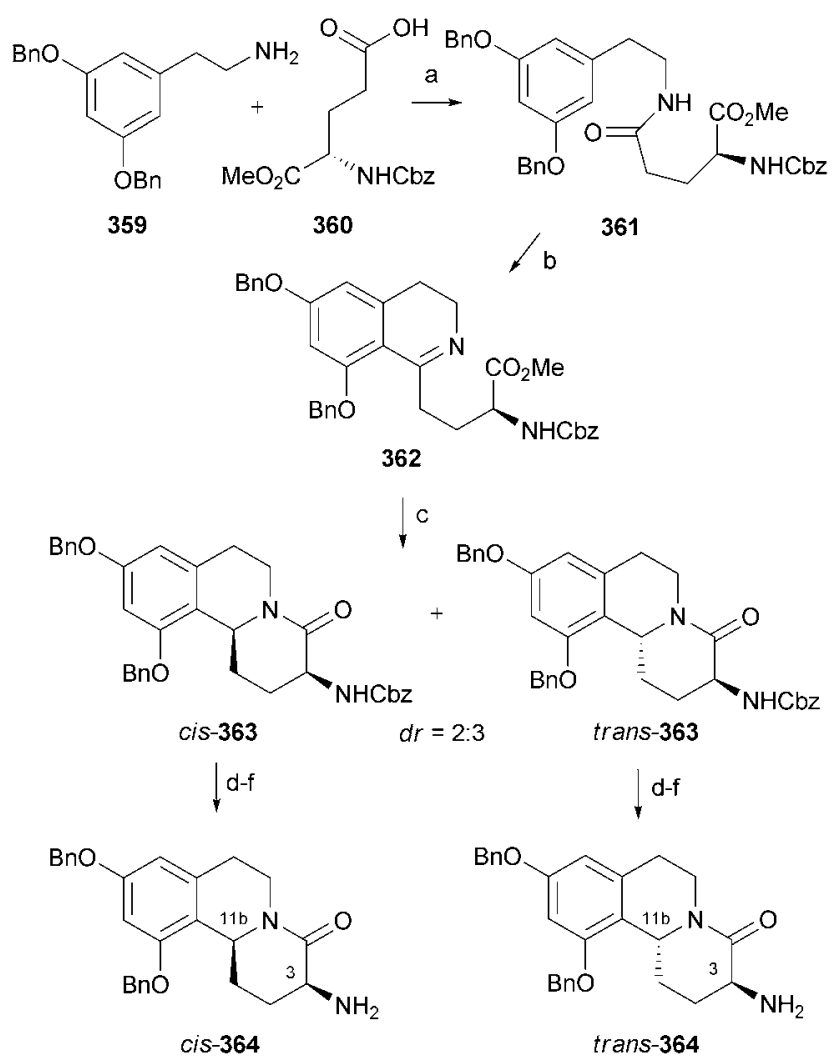

Scheme 54 Gurjar's synthesis of the schulzeine benzo[a]quinolizidine subunits. Reagents and conditions: (a) $\mathrm{EDC}, \mathrm{HOBt}, \mathrm{CH}_{2} \mathrm{Cl}_{2}, 0^{\circ} \mathrm{C} \rightarrow \mathrm{rt}$, $15 \mathrm{~h}, 84 \%$; (b) $\mathrm{POCl}_{3}, \mathrm{CHCl}_{3}, 70{ }^{\circ} \mathrm{C}, 3 \mathrm{~h}$; (c) $\mathrm{NaCNBH}_{3}, \mathrm{AcOH}-\mathrm{CH}_{2} \mathrm{Cl}_{2}$, $0{ }^{\circ} \mathrm{C}, 1 \mathrm{~h}$; then aq. $\mathrm{NaHCO}_{3}, \mathrm{rt}, 3 \mathrm{~h}$, cis-363 (26\%, 2 steps), trans-363 ( $39 \%, 2$ steps); (d) $\mathrm{H}_{2}, \mathrm{Pd} / \mathrm{C}, \mathrm{Boc}_{2} \mathrm{O}, \mathrm{MeOH}$; (e) $\mathrm{BnBr}, \mathrm{Cs}_{2} \mathrm{CO}_{3}, \mathrm{BuNI}$, $\mathrm{DMF}, 0{ }^{\circ} \mathrm{C}, 1 \mathrm{~h}$; (f) $3 \mathrm{M} \mathrm{HCl}-E t O A c, r t, 3 \mathrm{~h}$, cis-364 (84\%, 3 steps), trans364 ( $84 \%, 3$ steps). 


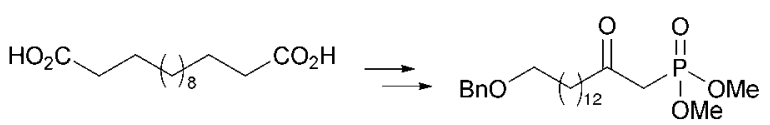

365

367

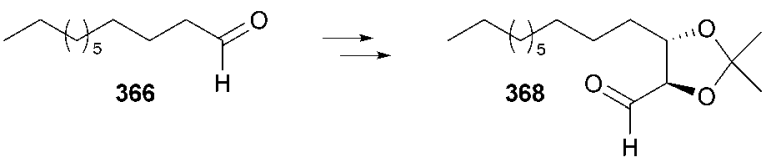

$367+368 \stackrel{a}{\longrightarrow}$
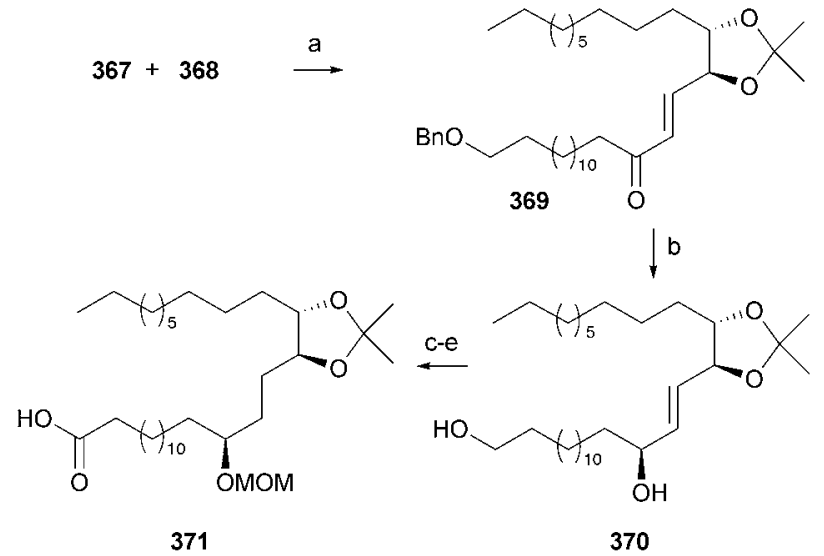

Scheme 55 Gurjar's synthesis of the side chain common to schulzeine B and C. Reagents and conditions: (a) $\mathrm{DBU}, \mathrm{LiCl}, \mathrm{CH}_{3} \mathrm{CN}, \mathrm{rt}, 1 \mathrm{~h}, 95 \%$; (b) (S)-(-)-BINAL-H (100 mol\%), THF, $-78{ }^{\circ} \mathrm{C}, 3 \mathrm{~h}, 84 \%, \mathrm{dr}=11: 1$; (c) MOMCl, DIPEA, rt, $\mathrm{CH}_{2} \mathrm{Cl}_{2}, 2 \mathrm{~h}, 97 \%$; (d) $\mathrm{H}_{2}, \mathrm{Pd}(\mathrm{OH})_{2} / \mathrm{C}$, EtOAc, $6 \mathrm{~h}$, $80 \%$; (e) IBX, DMSO, rt, $3 \mathrm{~h}$; (f) $\mathrm{NaClO}_{2}, \mathrm{NaH}_{2} \mathrm{PO}_{4} \cdot 2 \mathrm{H}_{2} \mathrm{O}, t-\mathrm{BuOH}-$ $\mathrm{H}_{2} \mathrm{O}, 0{ }^{\circ} \mathrm{C}, 2$ h, 2-methyl-2-butene, $88 \%$ (2 steps).

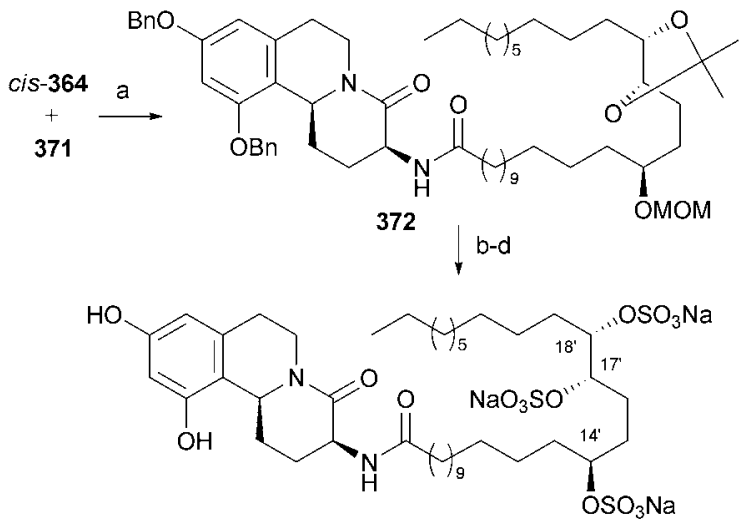

(-)-Schulzeine B (336)

Scheme 56 Gurjar's total synthesis of (-)-schulzeine B. Reagents and conditions: (a) EDC, $\mathrm{HOBt}, \mathrm{Et}_{3} \mathrm{~N}, \mathrm{CH}_{2} \mathrm{Cl}_{2}, \mathrm{rt}, 15 \mathrm{~h}, 72 \%$; (b) TMSI, $\mathrm{CH}_{2} \mathrm{Cl}_{2}-\mathrm{CH}_{3} \mathrm{CN}, 0{ }^{\circ} \mathrm{C}, 1 \mathrm{~h}, 47 \%$; (c) $\mathrm{SO}_{3} \cdot \mathrm{pyr}, \mathrm{DMF}, \mathrm{rt}, 30 \mathrm{~h}$; then $\mathrm{NaHCO}_{3}, 96 \%$ (d) $\mathrm{H}_{2}, \mathrm{Pd} / \mathrm{C}, \mathrm{MeOH}, \mathrm{rt}, 3$ h, $83 \%$.

approach, trichloromethyl- $\beta$-lactone (373) was converted via a straightforward, four-step protocol to vinyl ether $\mathbf{3 7 5}$ which, through recourse to a Corey-Link reaction $(377 \rightarrow 378),{ }^{174}$ was employed as a bis-homoserine aldehyde equivalent. ${ }^{175}$ Cyclization of $\mathbf{3 7 5}$ with phenylethylamine 359 under Pictet-Spengler conditions $\left(\mathrm{AcOH}, 100{ }^{\circ} \mathrm{C}\right)$ proceeded in high yield to provide 376a and 376b, albeit with negligible diastereoselectivity. After chromatographic separation, these tetrahydroisoquinolines were individually carried forward to tricyclic subunits of schulzeines $\mathrm{C}$ and $\mathrm{B}$, respectively. In this case of schulzeine $\mathrm{B}, \mathrm{N}$-protection of 376 $\mathbf{b}$ and treatment $\mathrm{NaOH} / \mathrm{NaN}_{3}$ led to the formation of $\alpha$-azido acid 378 which, without isolation, was converted to trans-benzo[a]quinolizidine 379. Selective reduction of the azide was now carried out using $\mathrm{Ph}_{3} \mathrm{P}$ and provided cis-364 suitably protected for coupling with the side chain.

Commencing with the alkylation of methyl acetoacetate (380) with allylic bromide 381, Romo's preparation of the schulzeine $\mathrm{B} / \mathrm{C}$ side chain 384 entailed introduction of the $\mathrm{C} 14^{\prime}$ stereogenic center, through Noyori hydrogenation of the resulting $\beta$-keto ester and dihydroxylation of compound 382 (Scheme 58). Employing Sharpless asymmetric conditions, dihydroxylation of this substrate proceeded with high diastereoselectivity to establish the $\mathrm{C} 16^{\prime} / 17^{\prime}$ diol system. After persilylation of the triol generated in this reaction, the remainder of the $C_{28}$ chain was introduced through partial reduction of the ester, Wittig olefination and simultaneous hydrogenation/hydrogenolysis to yield 384. Carbodiimide-mediated coupling of this carboxylic acid with amine cis-364 proceeded in moderate yield to provide 385 . Transformation to (-)-schulzeine B (336) was then accomplished through removal of the triethylsilyl groups, persulfation using pyridine-sulfur trioxide complex and hydrogenolysis. Following

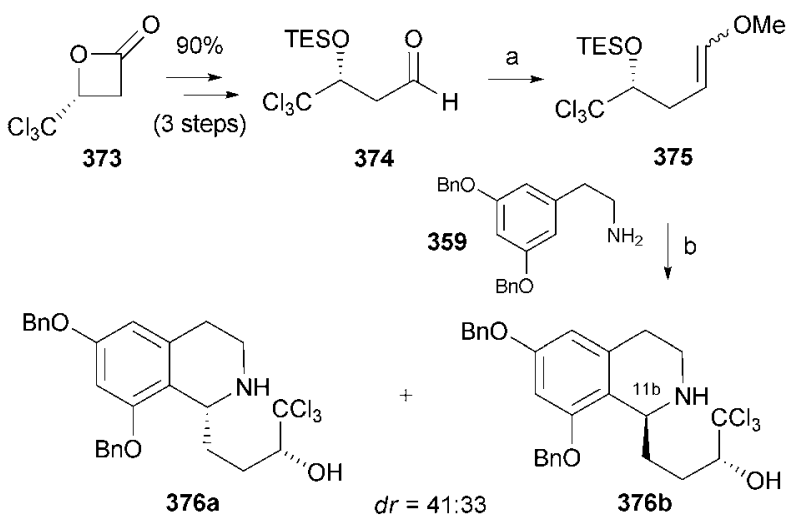

$\mathrm{BnO}$.<smiles>Cc1cc(Br)c2c(c1)CCN(C(=O)O)[C@H]2CC[C@H](N)C(=O)O</smiles><smiles>C1CCC2(CC1)CCCC21CCCCC1</smiles>

$\checkmark c$

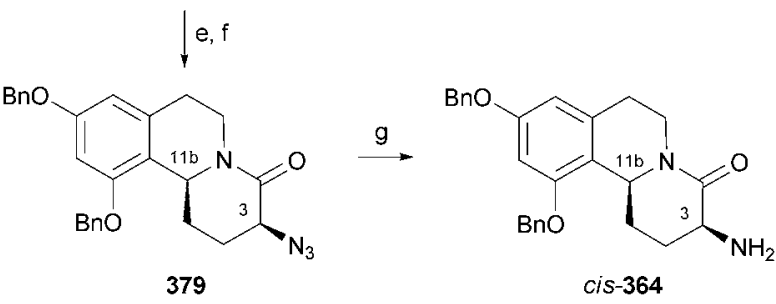

Scheme 57 Romo's synthesis of the schulzeine benzo[a]quinolizidine subunits. Reagents and conditions: (a) $\mathrm{Ph}_{3} \mathrm{P}^{+} \mathrm{CH}_{2} \mathrm{OMeI}^{-}$, LiHMDS, THF, 84\%, Z/E = 3: 2; (b) 359, AcOH, $100{ }^{\circ} \mathrm{C}, 24$ h, 376a (41\%), 376b (33\%); (c) $\mathrm{Boc}_{2} \mathrm{O}, \mathrm{CH}_{2} \mathrm{Cl}_{2}, \mathrm{Et}_{3} \mathrm{~N}, 92 \%$; (d) $\mathrm{NaOH}, \mathrm{NaN}_{3}, \mathrm{DME}-\mathrm{H}_{2} \mathrm{O}$ (1: 1); (e) TFA, $\mathrm{CH}_{2} \mathrm{Cl}_{2}, 0{ }^{\circ} \mathrm{C}$; (f) $\mathrm{Et}_{3} \mathrm{~N}$, DPPA, DMF, $47 \%$ (3 steps, 1 pot); (g) $\mathrm{PPh}_{3}, \mathrm{THF}-\mathrm{H}_{2} \mathrm{O}, 93 \%$. 
<smiles>CCCCCC=CCBr</smiles>
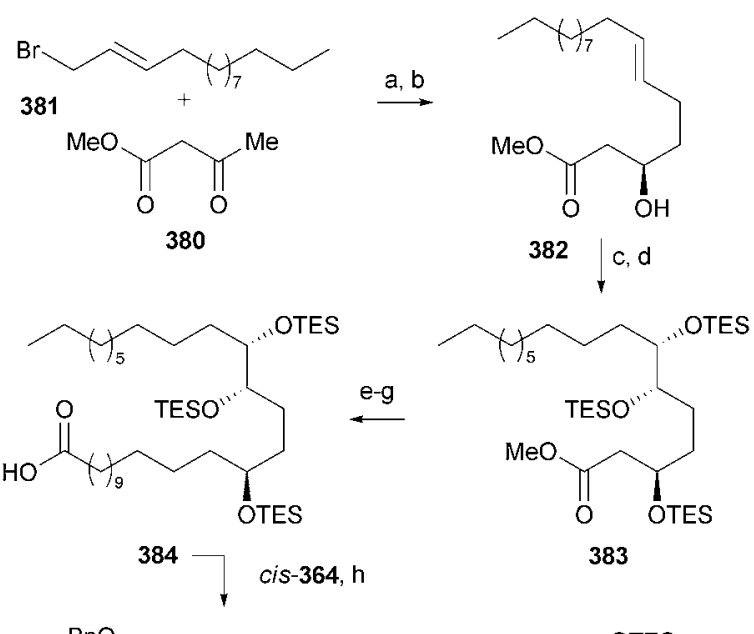

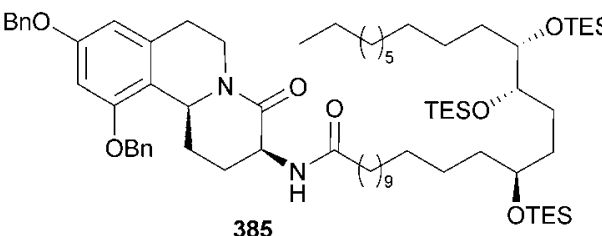
38 i-k

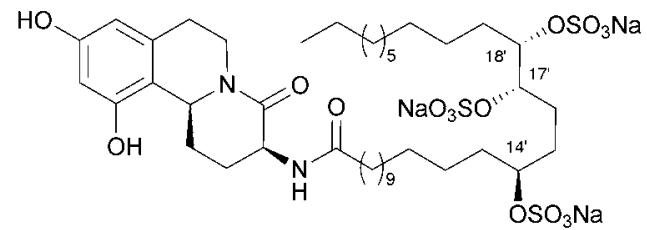

(-)-Schulzeine B (336)

Scheme 58 Romo's total synthesis of (-)-schulzeine B. Reagents and conditions: (a) NaH, $n$-BuLi, THF 76\%; (b) (R)-(BINAP) $\mathrm{RuBr}_{2}(5 \mathrm{~mol} \%$ ), $\mathrm{H}_{2}$ (6 atm), $\mathrm{MeOH}, 80{ }^{\circ} \mathrm{C}, 10 \mathrm{~min}, 70-90 \%$ (99\% brsm), $\mathrm{dr}>95: 5$; (c) AD-mix $\alpha, \mathrm{MeSONH}_{2}, t$ - $\mathrm{BuOH}-\mathrm{H}_{2} \mathrm{O}(1: 1), 76 \%$ (95\% brsm), dr > 19: 1 ; (d) $\mathrm{TESCl}, \mathrm{CH}_{2} \mathrm{Cl}_{2}, \mathrm{Et}_{3} \mathrm{~N}, 98 \%$; (e) DIBAL-H, $\mathrm{CH}_{2} \mathrm{Cl}_{2},-78{ }^{\circ} \mathrm{C}, 97 \%$; (f) $\mathrm{BnO}_{2} \mathrm{C}\left(\mathrm{CH}_{2}\right)_{9} \mathrm{CH}_{2} \mathrm{PPh}_{3} \mathrm{Br}$, KHMDS, THF, 95\%; (g) H $\mathrm{H}_{2}$, Pd/C, 2,6-lutidine, $\mathrm{EtOH}, 95 \%$; (h) EDCI, HOBt, $\mathrm{Et}_{3} \mathrm{~N}$, DMF, 65\%; (i) AcOH, THF$\mathrm{H}_{2} \mathrm{O}, 99 \%$; (j) $\mathrm{SO}_{3} \cdot$ pyr, DMF, $0 \rightarrow 23{ }^{\circ} \mathrm{C}$; (k) $\mathrm{H}_{2}, \mathrm{Pd} / \mathrm{C}, \mathrm{MeOH}, 82 \%$ (2 steps).

the same sequence of steps, but employing trans-364 in place of cis-364, (+)-schulzeine C (335) was also prepared.

The first total synthesis of schulzeine A (334) was reported in 2009 by Wardrop and Bowen, who in addition to preparing schulzeine B (336) and C (335), demonstrated that the absolute configuration originally assigned to the $\mathrm{C} 20^{\prime}$ stereocenter of this natural product should be revised (Schemes 59-61). ${ }^{176}$ While employing L-glutamate in the preparation of the benzo[a]quinolizidine subunit (as in the work of Kuntiyong and Gurjar), Wardrop's overall synthetic strategy differs from that of Gurjar and Romo in that introduction of the $\mathrm{C} 17^{\prime}$ and $\mathrm{C} 18^{\prime}$ stereogenic centers occurs after coupling of the alkaloid and side chain subunits.

Preparation of the aminobenzo[ $a]$ quinolizidine subunits present in schulzeine A, B and C commenced with the assembly of cyclization precursor $\mathbf{3 8 8}$ from L-glutamic acid $\gamma$-methyl ester 386 and 2-[3,5-bis(benzyloxy)phenyl]ethylamine (359) (Scheme 59). Unanticipated interference of the $N$-Boc group during the subsequent Pictet-Spengler reaction mandated the exchange of this carbamate for a more robust $N$-phthalimide group. This task was accomplished by treatment of $\mathbf{3 8 7}$ with ethereal $\mathrm{HCl}$ and $N$-phthaloylation of the resulting primary amine with $N$ (ethoxycarbonyl)phthalimide. Oxidation of the primary alcohol, under Swern conditions, then generated $\alpha$-hydroxy- $\delta$-lactam 388, which arises from cyclization of the unstable aldehyde. Exposure of 388 to a range of Pictet-Spengler promoters, including $\mathrm{BF}_{3} \cdot \mathrm{Et}_{2} \mathrm{O}$, acetic or trifluoroacetic acid, led to the selective formation of $\mathrm{cis}$ $389\left(\mathrm{C} 11 \mathrm{~b}-\mathrm{H}_{\alpha}\right)$ with a cis/trans selectivity ranging from $2: 1$ to $9: 1$. While cis and trans-389 proved to be inseparable by flash chromatography, diastereomer separation was achieved after hydrazinolysis of the phthalimide group and formation of carbamates cis and trans-390. Treatment of these individual diastereomers with TFA then afforded trans- and cis-364, the benzo[a]quinolizidine subunits required for the synthesis of schulzeines $\mathrm{A}$ and $\mathrm{C}$, and schulzeine B, respectively.

Wardrop's construction of the two distinct schulzeine $\mathrm{C}_{28}$ trisulfate sides began from $\omega$-hydroxy ester 391, which was converted to 392 through a sequence of oxidation, Keck enantioselective allylation and silylation (Scheme 60). After introduction of a 1-phenyl-1 $H$-tetrazol-5-yl sulfone group, assembly<smiles>COC(=O)CCC(NC(=O)OCc1ccccc1)C(=O)O</smiles>

$\mathrm{BnO}$<smiles>Cc1cc2c(c(C(=O)O)c1)[C@@H]1CC[C@@H](Nc3ccccc3)C(=O)N1CC2</smiles>
389<smiles>CC1CN2C(=O)[C@@H](NC(=O)OC(C)(C)C)CC[C@H]2c2c(OCc3ccccc3)cc(OCc3ccccc3)cc21</smiles><smiles>[V]=[Tl]</smiles>

$\mathrm{BnO}$<smiles>Cc1cc(O)c2c(c1)CCN1C(=O)[C@H](N)CC[C@H]21</smiles>
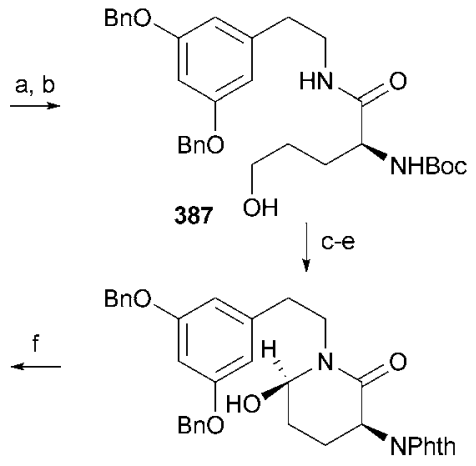

$\mathrm{BnO}$

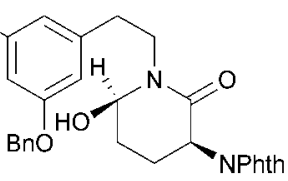

388
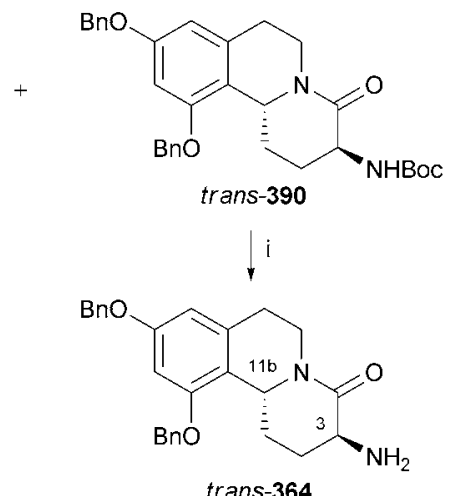

Scheme 59 Wardrop's synthesis of the schulzeine benzo[a]quinolizidine subunits. Reagents and conditions: (a) $i$ - $\mathrm{BuOCOCl}, \mathrm{NMM}, \mathrm{CH}_{2} \mathrm{Cl}_{2}$, DMF, $-35{ }^{\circ} \mathrm{C}, 15 \mathrm{~min}$; then 2-[3,5-bis(benzyloxy)phenyl]ethylamine, DMF, $\mathrm{CH}_{2} \mathrm{Cl}_{2}$, rt, $12 \mathrm{~h}$; (b) $\mathrm{NaBH}_{4}, \mathrm{LiCl}$, THF, $\mathrm{MeOH}, 0{ }^{\circ} \mathrm{C}, 5.5 \mathrm{~h}$; (c) 1 $\mathrm{M} \mathrm{HCl}$ in $\mathrm{Et}_{2} \mathrm{O}, \mathrm{CH}_{2} \mathrm{Cl}_{2}$, rt, $2 \mathrm{~h}$; (d) PhthNCOOEt, $\mathrm{Na}_{2} \mathrm{CO}_{3}$, THF, rt, 16 h; (e) Swern oxidation; (f) AcOH, $\mathrm{CH}_{2} \mathrm{Cl}_{2}, \mathrm{rt}, 2 \mathrm{~h}$; (g) $\mathrm{H}_{2} \mathrm{NNH}_{2}$, EtOH, rt, $24 \mathrm{~h}$; (h) $\mathrm{Boc}_{2}(\mathrm{O}), \mathrm{CH}_{2} \mathrm{Cl}_{2}, \mathrm{rt}, 1 \mathrm{~h}$, cis-390 (57\%), trans-390 (26\%); (i) TFA, $\mathrm{CH}_{2} \mathrm{Cl}_{2}, 0{ }^{\circ} \mathrm{C}, 1 \mathrm{~h}$, cis-364 (98\%), trans-364 (85\%). 


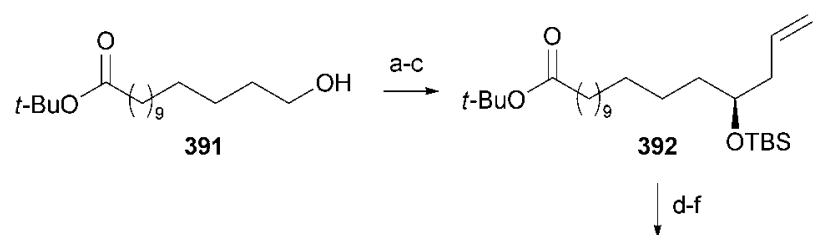

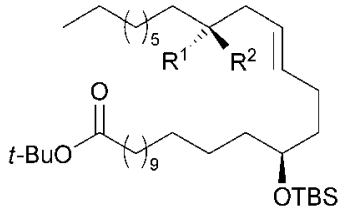

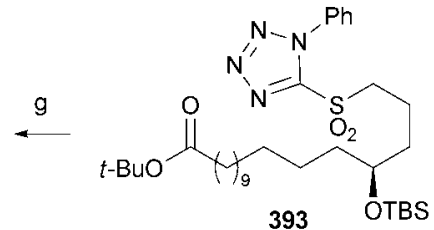

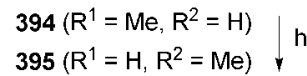

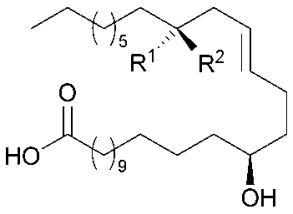<smiles>CCCCCC=CCC[C@H](O)CCCNC(=O)O</smiles>

$396\left(R^{1}=M e, R^{2}=H\right)$ $397\left(R^{1}=H, R^{2}=M e\right)$

398

Scheme 60 Wardrop's synthesis of the schulzeine A, B and C side chain subunits. Reagents and conditions: (a) Moffat-Swern oxidation; (b) $(R)$ (+)-1,1'-bi-2-napthol (10 mol\%), Ti(O-i-Pr) $)_{4}, 4 \AA \mathrm{MS}, \mathrm{CH}_{2} \mathrm{Cl}_{2}$, reflux $1 \mathrm{~h}$; then $-78{ }^{\circ} \mathrm{C}$, allyl tri- $n$-butylstannane, $-20{ }^{\circ} \mathrm{C}, 5 \mathrm{~d}, 75 \%$ ( 2 steps), ee $>$ 98\%; (c) TBSCl, imidazole, $\mathrm{CH}_{2} \mathrm{Cl}_{2}, 0{ }^{\circ} \mathrm{C} \rightarrow \mathrm{rt}, 18 \mathrm{~h}, 97 \%$; (d) 9-BBN, THF, $0{ }^{\circ} \mathrm{C} \rightarrow \mathrm{rt}, 14 \mathrm{~h}$; then $\mathrm{H}_{2} \mathrm{O}_{2}, \mathrm{NaOH}, \mathrm{B}(\mathrm{OH})_{3}, \mathrm{rt}, 1 \mathrm{~h}, 94 \%$; (e) $1-$ phenyl- $1 \mathrm{H}$-tetrazole-5-thiol, DIAD, $\mathrm{Ph}_{3} \mathrm{P}$, THF, $0{ }^{\circ} \mathrm{C} \rightarrow \mathrm{rt}, 12 \mathrm{~h}, 91 \%$; (f) $\left(\mathrm{NH}_{4}\right)_{6} \mathrm{Mo}_{7} \mathrm{O}_{24} \cdot 4 \mathrm{H}_{2} \mathrm{O}\left(20 \mathrm{~mol}^{\circ}\right), \mathrm{H}_{2} \mathrm{O}_{2}, \mathrm{EtOH}, 0{ }^{\circ} \mathrm{C} \rightarrow \mathrm{rt}, 14 \mathrm{~h}, 99 \% ;(\mathrm{g})$ KHMDS, DME, $-60{ }^{\circ} \mathrm{C}, 30 \mathrm{~min}$, then $(S)$-3-methylundecanal, $-60^{\circ} \mathrm{C}$ $\rightarrow \mathrm{rt}, 16 \mathrm{~h}, 394(45 \%, \mathrm{dr}>20: 1)$; KHMDS, DME, $-60^{\circ} \mathrm{C}, 30 \mathrm{~min}$, then (R)-3-methylundecanal, $-60{ }^{\circ} \mathrm{C} \rightarrow \mathrm{rt}, 16 \mathrm{~h}, 395$ (75\%, dr > $\left.20: 1\right)$; (h) HF, TBAF, THF, rt, 48 h; 1 M NaOH-EtOH-THF, reflux, 48 h, 396 $(70 \%), 397(84 \%)$.

of the complete lipid subunit was accomplished using the JuliaKocienski protocol. In the case of schulzeine A (332, proposed), this involved reaction of the anion of 393 with $(S)$-3-methylundecanal to give 394, while 398, the less complex side chain of schulzeine B (336) and C (335), was generated from 393 and undecanal. In each case, alkene formation proceeded with high selectivity for the required $E$-isomer. Deprotection of 394, through sequential exposure to $\mathrm{HF}-\mathrm{TBAF}$ and aqueous $\mathrm{NaOH}$, then provided carboxylic acid 396. Compound 397, the $\mathrm{C} 20^{\prime}$ epimer of 396, was subsequently prepared in similar fashion from (R)-3-methylundecanal.

Synthesis of the compound proposed by Fusetani to be schulzeine A (333, 20'-epi-schulzeine A) was now completed by first coupling fragments trans-364 and 396 to provide 398 (Scheme 61). Introduction of the $\mathrm{C} 17^{\prime} / 18^{\prime}$ diol was carried out via reagent-controlled Sharpless asymmetric dihydroxylation, which provided $\mathbf{4 0 0}$ with reasonable diastereoselectivity. Persulfation of this triol, using sulfur trioxide-pyridine complex in DMF, and hydrogenolysis of the benzyl ethers now provided $20^{\prime}$-epi-schulzeine A (333). At this stage, discrepancies between the ${ }^{1} \mathrm{H}$ and ${ }^{13} \mathrm{C}$ NMR spectral data of this material and those collected from the
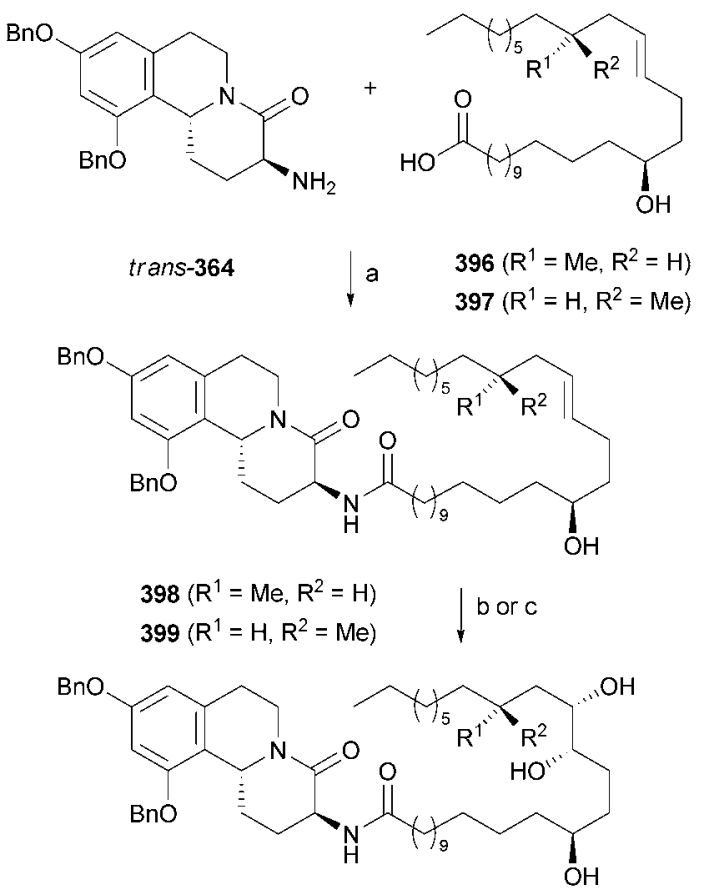

$\begin{aligned} & 400\left(R^{1}=M e, R^{2}=H\right) \\ & 401\left(R^{1}=H, R^{2}=M e\right)\end{aligned} \quad \downarrow d, e$

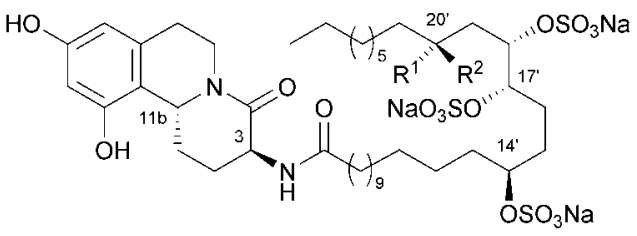

(+)-epi-20'S-Schulzeine A (333, $\left.\mathrm{R}^{1}=\mathrm{Me}, \mathrm{R}^{2}=\mathrm{H}\right)$ proposed structure

(+)-Schulzeine A (334, $\left.\mathrm{R}^{1}=\mathrm{H}, \mathrm{R}^{2}=\mathrm{Me}\right)$ revised structure

Scheme 61 Wardrop's total synthesis of (+)-schulzeine A and (+)-epi$20^{\prime} S$-schulzeine A. Reagents and conditions: (a) (i) $\mathrm{EDC}, \mathrm{CH}_{2} \mathrm{Cl}_{2}, \mathrm{rt}, 16 \mathrm{~h}$, 398 (73\%), 399 (80\%); (b) AD-mix $\alpha, \mathrm{MeSO}_{2} \mathrm{NH}_{2}, t$-BuOH- $t$-BuOMe$\mathrm{H}_{2} \mathrm{O}$-THF $(1: 1: 1: 1), 0{ }^{\circ} \mathrm{C}, 18 \mathrm{~h}, \mathbf{4 0 0}(83 \%, \mathrm{dr}=4: 1)$; (c) AD-mix $\alpha$, $\mathrm{MeSO}_{2} \mathrm{NH}_{2}, t$-BuOH- $t$-BuOMe- $\mathrm{H}_{2} \mathrm{O}(1: 1: 1), 0{ }^{\circ} \mathrm{C}, 48 \mathrm{~h}, 401(77 \%$, $\mathrm{dr}=91$ : 9); (d) $\mathrm{SO}_{3} \cdot$ pyr, DMF, rt, 2 h; (e) $\mathrm{H}_{2}, \mathrm{Pd} / \mathrm{C}, \mathrm{EtOH}, \mathrm{rt}, 8$ h, 333 (88\%, two steps); 334 (75\%, two steps).

natural product suggested that the original stereochemical assignment at $\mathrm{C} 20^{\prime}$ required re-evaluation and prompted the authors to prepare the $\mathrm{C} 20^{\prime}$ epimer of 333 , i.e. schulzeine $\mathrm{A}(\mathbf{3 3 4})$. From (S)-3-methylundecanal, compound 332 was accessed by way of carboxylic acid 397, alkene 399 and triol 401. The ${ }^{1} \mathrm{H}$ and ${ }^{13} \mathrm{C}$ NMR spectra of synthetic $\mathbf{3 3 3}$ were found to be consistent with those reported by Fusetani for natural schulzene A, thus supporting the premise that the stereochemistry at $\mathrm{C} 20^{\prime}$ should be reassigned as the $R$-configuration.

Following the same strategy employed in the assembly of schulzeine $\mathrm{A}$ and its $\mathrm{C} 20^{\prime}$ epimer, the total syntheses of schulzeine B (336) and schulzeine C (335) were also completed. In the case of schulzeine $B$, this involved the use of aminobenzo[a]quinolizidine cis-364. 


\section{Conclusions}

As is clear from this review, interest in the total synthesis of natural products which display anti- $\alpha$-glucosidase activity has not waned in the last five years, reflecting the importance of such compounds in both medical and chemical research. With regard to alkaloid-based inhibitors, few natural product types have provoked such intense and sustained interest in their preparation, and while the majority of this work has been focused on the application and evaluation of synthetic methodology, an increasing number of studies employ total synthesis as a means to an end, beyond simply accessing the natural product. This focus on function rather than preparation has been particularly prevalent in the thiosugar area, where the therapeutic potential of compounds such as salicinol demands a deeper understanding of their mode of action.

Future goals for this field of research include the discovery, synthesis and development of new inhibitors, which display increased potency and, above all, inter-glycosidase selectivity. In this context, the schulzeines and related organosulfates are of particular interest in light of their biological activity and, as yet, unknown mode of action. In addition to providing a means with which to accomplish these goals, synthetic chemistry has also played a pivotal role in the structural determination of a number of natural products, including kotalanol, its de- $O$-sulfonated derivative and schulzeine $\mathrm{A}$. The knowledge gained from the total synthesis of these and other natural product targets will continue to be of central importance in the future discovery and development of $\alpha$-glucosidase inhibitors.

\section{Acknowledgements}

We thank UIC and the National Institutes of Health (GM59157) for financial support and Professor Yoichi Nakao for helpful discussions regarding the structure of schulzeine A.

\section{References}

1 G. J. Davies, T. M. Gloster and B. Henrissat, Curr. Opin. Struct. Biol., 2005, 15, 637.

2 N. Asano, Cell. Mol. Life Sci., 2009, 66, 1479; N. Asano, Glycobiology, 2003, 13, 93R.

3 B. P. Rempel and S. G. Withers, Glycobiology, 2008, 18, 570.

4 M. Jung, M. Park, H. C. Lee, Y. H. Kang, E. S. Kang and S. K. Kim, Curr. Med. Chem., 2006, 13, 1203; B. Morgan, Drug Discovery Today, 2004, 9, 201; L. Somsak, V. Nagy, Z. Hadady, T. Docsa and P. Gergely, Curr. Pharm. Des., 2003, 9, 1177.

5 M. von Itzstein, Nat. Rev. Drug Discovery, 2007, 6, 967; J. Zhang and W. Wu, Mini-Rev. Med. Chem., 2006, 6, 429.

6 I. Robina, A. J. Moreno-Vargas, A. T. Carmona and P. Vogel, Curr. Drug Metab., 2004, 5, 329 (HIV)C. Chapel, C. Garcia, B. Bartosch, P. Roingeard, N. Zitzmann, F. L. Cosset, J. Dubuisson, R. A. Dwek, C. Trepo, F. Zoulim and D. Durantel, J. Gen. Virol., 2007, 88, 1133 (HCV).

7 P. Greimel, J. Spreitz, A. E. Stütz and T. M. Wrodnigg, Curr. Top. Med. Chem., 2003, 3, 513.

8 T. D. Butters, R. A. Dwek and F. M. Platt, Glycobiology, 2005, 15, 43R.

9 US Pat., 0186 862, 2009.

10 T. M. Wrodnigg, A. J. Steiner and B. J. Ueberbacher, Anti-Cancer Agents Med. Chem., 2008, 8, 77; Y. Nishimura, Curr. Top. Med. Chem., 2003, 3, 575.

11 For recent reviews of the preparation of glycosidase inhibitors, see: P. Compain, V. Chagnault and O. R. Martin, Tetrahedron: Asymmetry, 2009, 20, 672; M. S. M. Pearson, M. Mathe-Allainmat,
V. Fargeas and J. Lebreton, Eur. J. Org. Chem., 2005, 2159; K. Afarinkia and A. Bahar, Tetrahedron: Asymmetry, 2005, 16, 1239.

12 D. J. Vocadlo and G. J. Davies, Curr. Opin. Chem. Biol., 2008, 12, 539; A. Vasella, G. J. Davies and M. Böhm, Curr. Opin. Chem. Biol., 2002, 6, 619; D. L. Zechel and S. G. Withers, Acc. Chem. Res., 2000, 33, 11; J. D. McCarter and W. G. Stephen, Curr. Opin. Struct. Biol., 1994, 4, 885; M. L. Sinnott, Chem. Rev., 1990, 90, 1171. 13 D. E. Koshland Jr., Biol. Rev., 28, p. 416.

14 T. M. Gloster and G. J. Davies, Org. Biomol. Chem., 2010, 8, 305; T. M. Gloster, P. Meloncelli, R. V. Stick, D. Zechel, A. Vasella and G. J. Davies, J. Am. Chem. Soc., 2007, 129, 2345.

15 V. H. Lillelund, H. H. Jensen, X. Liang and M. Bols, Chem. Rev., 2002, 102, 515; P. Sears and C.-H. Wong, Angew. Chem., Int. Ed., $1999, \mathbf{3 8}, 2300$

16 Heightman and A. T. Vasella, Angew. Chem., Int. Ed., 1999, 38, 750. 17 M. Bols, Acc. Chem. Res., 1998, 31, 1.

18 B. Ganem and G. Papandreou, J. Am. Chem. Soc., 1991, 113, 8984; G. Papandreou, M. K. Tong and B. Ganem, J. Am. Chem. Soc., 1993, 115, 11682.

19 I. Nakao, K. Katsu, N. Taro, T. Takashi and Y. Hiroshi, J. Antibiot., 1967, 20, 66; S. E. Inouye, Y. Tsuruoka, T. Ito and T. Niida, Tetrahedron, 1968, 24, 2125.

20 Iminosugars as Glycosidase Inhibitors: Nojirimycin and Beyond, ed. A. E. Stütz, Wiley-VCH, New York, 1999; N. Asano, Curr. Top. Med. Chem., 2003, 3, 471.

21 P. Compain and O. R. Martin, Bioorg. Med. Chem., 2001, 9, 3077; P. Compain and O. R. Martin, Curr. Top. Med. Chem., 2003, 3, 541; W. Zou, Curr. Top. Med. Chem., 2005, 5, 1363.

22 P. Jakobsen, J. M. Lundbeck, M. Kristiansen, J. Breinholt, H. Demuth, J. Pawlas, C. Torres, P. Maria, B. Andersen, N. Westergaard, K. Lundgren and N. Asano, Bioorg. Med. Chem., 2001, 9, 733; B. R. Henke and S. M. Sparks, Mini-Rev. Med. Chem., 2006, 6, 845.

23 A. Fedorov, W. Shi, G. Kicska, E. Fedorov, P. C. Tyler, R. H. Furneaux, J. C. Hanson, G. J. Gainsford, J. Z. Larese, V. L. Schramm and S. C. Almo, Biochemistry, 2001, 40, 853.

24 M. Yagi, T. Kouno, Y. Aoyagi and H. Murai, J. Agric. Chem. Soc. Jpn., 1976, 50, 571; D. D. Schmidt, W. Frommer, L. Muller and E. Truscheit, Naturwissenschaften, 1979, 66, 584.

25 For a summary of this data, see: C. W. Ekhart, M. H. Fechter, P. Hadwiger, E. Mlaker, A. E. Stütz, A. Tauss, and T. M. Wrodnigg in Iminosugars as Glycosidase Inhibitors: Nojirimycin and Beyond, ed. A. E. Stütz, Wiley-VCH, New York, 1999 , pp. 292-295.

26 H. Paulsen, Angew. Chem., Int. Ed. Engl., 1966, 5, 495; H. Paulsen, I. Sangster and K. Heyns, Chem. Ber., 1967, 100, 802.

27 For reviews of these efforts, see:A. B. Huges and A. J. Rudge, Nat. Prod. Rep., 1994, 11, 135; K. Afarinkia and A. Bahar, Tetrahedron: Asymmetry, 2005, 16, 1239.

28 G. Danoun, J. Ceccon, A. E. Greene and J. F. Poisson, Eur. J. Org. Chem., 2009, 4221.

29 H. Takahata, Y. Banba, M. Sasatani, H. Nemoto, A. Kato and I. Adachi, Tetrahedron, 2004, 60, 8199.

30 S. Al-Rawi, S. Hinderlich, W. Reutter and A. Giannis, Angew. Chem., Int. Ed., 2004, 43, 436.

31 I. S. Kim, H. Y. Lee and Y. H. Jung, Heterocycles, 2007, 71, 1787.

32 W. R. Roush and P. T. Grover, Tetrahedron, 1992, 48, 1981.

33 H. Yokohama, H. Kobayashi, M. Miyazawa, S. Yamaguchi and Y. Hirai, Heterocycles, 2007, 74, 283.

34 A. Roy, B. Achari and S. B. Mandal, Synthesis, 2006, 6, 1035.

35 G. W. Fleet, A. Karpas, R. A. Dwek, L. E. Fellows, A. S. Tyms, S. Petursson, S. K. Namgoong, N. G. Ramsden, P. W. Smith, J. C. Son, F. Wilson, D. R. Witty, G. S. Jacob and T. W. Rademacher, FEBS Lett., 1988, 237, 128.

36 H. R. Mellor, J. Nolan, L. Pickering, M. R. Wormald, F. M. Platt, R. A. Dwek, G. W. J. Fleet and T. D. Butters, Biochem. J., 2002, 366, 225.

37 N. Asano, H. Kizu, K. Oseki, E. Tomioka, K. Matsui, M. Okamoto and M. Baba, J. Med. Chem., 1995, 38, 2349.

38 A. J. Rawlings, H. Lomas, A. W. Pilling, M. J. Lee, D. S. Alonzi, J. S. Rountree, S. F. Jenkinson, G. W. Fleet, R. A. Dwek, J. H. Jones and T. D. Butters, ChemBioChem, 2009, 10, 1101.

39 D. S. Alonzi, R. A. Dwek and T. D. Butters, Tetrahedron: Asymmetry, 2009, 20, 897.

40 Y. Zhou and P. V. Murphy, Org. Lett., 2008, 10, 3777. 
41 D. D. Long, M. D. Smith, A. Martin, J. R. Wheatley, D. G. Watkin, M. Muller and G. W. J. Fleet, J. Chem. Soc., Perkin Trans. 1, 2002, 1982.

42 M. Ruiz, T. M. Ruanova, O. Blanco, F. Nunez, C. Pato and V. Ojea, J. Org. Chem., 2008, 73, 2240.

43 L. Cipolla, M. R. Fernandes, M. Gregori, C. Airoldi and F. Nicotra, Carbohydr. Res., 2007, 342, 1813.

44 N. Asano, M. Nishida, M. Miyauchi, K. Ikeda, M. Yamamoto, H. Kizu, Y. Kameda, A. A. Watson, R. J. Nash and G. W. J. Fleet, Phytochemistry, 2000, 53, 379.

45 K. Ikeda, M. Takahashi, M. Nishida, M. Miyauchi, H. Kizu, Y. Kameda, M. Arisawa, A. A. Watson, R. J. Nash, G. W. J. Fleet and N. Asano, Carbohydr. Res., 1999, 323, 73.

46 F.-X. Felpin, K. Boubekeur and J. Lebreton, J. Org. Chem., 2004, 69, 1497.

47 M. S. M. Pearson, R. O. Saad, T. Dintinger, H. Amri, M. MathéAllainmat and J. Lebreton, Bioorg. Med. Chem. Lett., 2006, 16, 3262.

48 M. S. M. Pearson, M. Evain, M. Mathé-Allainmat and J. Lebreton, Eur. J. Org. Chem., 2007, 4888.

49 C. Yu, N. Asano, K. Ikeda, M. Wang, T. D. Butters, M. R. Wormald, A. L. W. Raymond, A. Dwek, R. J. Nash and G. W. T. Fleet, Chem. Commun., 2004, 1936.

50 For a recent review of synthetic efforts towards these targets, see: B. L. Stocker, E. M. Dangerfield, A. L. Win-Mason, G. W. Haslett and M. S. M. Timmer, Eur. J. Org. Chem., 2010, 1615.

51 M. I. García-Moreno, M. Aguilar, M. C. Ortiz and J. M. Garcia Fernández, Org. Lett., 2006, 8, 297.

52 B. M. Trost, D. B. Horne and M. J. Woltering, Chem. Eur. J., 2006, 12, 6607.

53 A. Lauritsen and R. Madsen, Org. Biomol. Chem., 2006, 4, 2898.

54 T. J. Donohoe, M. D. Cheeseman, T. J. C. O'Riordan and J. A. Kershaw, Org. Biomol. Chem., 2008, 6, 3896.

55 (a) T. J. Donohoe, C. L. Rigby, R. E. Thomas, W. F. Nieuwenhuys, F. L. Bhatti, A. R. Cowley, G. Bhalay and I. D. Linney, J. Org. Chem., 2006, 71, 6298; (b) T. J. Donohoe, C. E. Headley, R. P. C. Cousins and A. Cowley, Org. Lett., 2003, 5, 999; (c) T. J. Donohoe, R. E. Thomas, M. D. Cheeseman, C. L. Rigby, G. Bhalay and I. Linney, Org. Lett., 2008, 10, 3615.

56 R. J. Molyneux, M. Benson, R. Y. Wong, J. E. Tropea and A. D. Elbein, J. Nat. Prod., 1988, 51, 1198.

57 J. E. Tropea, R. J. Molyneux, G. P. Kaushal, Y. T. Pan, M. Mitchell and A. D. Elbein, Biochemistry, 1989, 28, 2027.

58 A. J. Vlietinck, T. De Bruyne, S. Apers and L. A. Pieters, Planta Med., 1998, 64, 97.

59 B. M. Trost, A. Aponick and B. N. Stanzl, Chem. Eur. J., 2007, 13, 9547.

60 C. Ribes, E. Falomir, M. Carda and J. A. Marco, Org. Lett., 2007, 9, 77.

61 C. Ribes, E. Falomir, M. Carda and J. A. Marco, Tetrahedron, 2009, 65, 6965 .

62 R. J. Nash, P. I. Thomas, R. D. Waigh, G. W. J. Fleet, M. R. Wormald, Q. L. de, M. Paul and D. J. Watkin, Tetrahedron Lett., 1994, 35, 7849.

63 F. Cardona, C. Parmeggiani, E. Faggi, C. Bonaccini, P. Gratteri, L. Sim, T. M. Gloster, S. Roberts, G. J. Davies, D. R. Rose and A. Goti, Chem. Eur. J., 2009, 15, 1627.

64 P. DeShong, J. M. Leginus and S. W. Lander, J. Org. Chem., 1986, 51, 574.

65 I. Izquierdo, M. T. Plaza and J. A. Tamayo, Tetrahedron, 2005, 61, 6527.

66 J. V. Ameijde, G. Horne, M. R. Wormald, R. A. Dwek, R. J. Nash, P. W. Jones, E. L. Evinson and G. W. J. Fleet, Tetrahedron: Asymmetry, 2006, 17, 2702.

67 S. Stecko, J. Solecka and M. Chmielewski, Carbohydr. Res., 2009, 344, 167.

68 S. Stecko, M. Jurczak, Z. Urbanczyk-Lipkowska, J. Solecka and M. Chmielewski, Carbohydr. Res., 2008, 343, 2215; D. Socha, M. Jurczak and M. Chmielewski, Carbohydr. Res., 2001, 336, 315.

69 N. Asano, H. Kuroi, K. Ikeda, H. Kizu, Y. Kameda, A. Kato, I. Adachi, A. A. Watson, R. J. Nash and G. W. J. Fleet, Tetrahedron: Asymmetry, 2000, 11, 1.

70 P. Dewi-Wulfing and S. Blechert, Eur. J. Org. Chem., 2006, 1852.

71 D. Koch, S. Maechling and S. Blechert, Tetrahedron, 2007, 63, 7112.

72 S. Desvergnes, S. Py and Y. Valleé, J. Org. Chem., 2005, 70, 1459.
73 G. Masson, P. Cividino, S. Py and Y. Valleé, Angew. Chem., Int. Ed., $2003,42,2265$

74 L. Chabaud, Y. Landais and P. Renaud, Org. Lett., 2005, 7, 2587.

75 T. J. Donohoe, H. O. Sintim and J. Hollinshead, J. Org. Chem., $2005,70,7297$.

76 T. J. Donohoe, R. E. Thomas, M. D. Cheeseman, C. L. Rigby, G. Bhalay and I. D. Linney, Org. Lett., 2008, 10, 3615.

77 P. V. Reddy, A. Veyron, P. Koos, A. Bayle, A. E. Greene and P. Delair, Org. Biomol. Chem., 2008, 6, 1170.

78 C. Roche, K. Kadlecíková, A. Veyron, P. Delair, C. Philouze, A. E. Greene, D. Flot and M. Burghammer, J. Org. Chem., 2005, 70, 8352 .

79 S. Chandrasekhar, B. B. Parida and C. Rambabu, J. Org. Chem., 2008, 73, 7826

80 M. Miyashita, T. Mizutani, G. Tadano, Y. Iwata, M. Miyazawa and K. Tanino, Angew. Chem., Int. Ed., 2005, 44, 5094.

81 R. J. Nash, L. E. Fellows, J. V. Dring, G. W. J. Fleet, A. E. Derome, T. A. Hamor, A. M. Scofield and D. J. Watkin, Tetrahedron Lett., 1988, 29, 2487.

82 M. Dressel, P. Restorp and P. Somfai, Chem. Eur. J., 2008, 14, 3072.

83 R. Appel, Angew. Chem., Int. Ed. Engl., 1975, 14, 801.

84 (a) L. D. Hohenschutz, E. A. Bell, P. J. Jewess, D. P. Leworthy, R. J. Pryce, E. Arnold and J. Clardy, Phytochemistry, 1981, 20, 811; (b) R. J. Nash, L. E. Fellows, J. V. Dring, C. H. Stirton, D. Carter, M. P. Hegarty and E. A. Bell, Phytochemistry, 1988, 27, 1403.

85 For an earlier review of the synthesis of indolizidine alkaloids, see: J. P. Michael, Nat. Prod. Rep., 2007, 24, 191.

86 Y. Tanaka, J. Kato, M. Kohara and M. S. Galinski, Antiviral Res., 2006, 72, 1 (parainfluenza); K. Whitby, T. C. Pierson, B. Geiss, K. Lane, M. Engle, Y. Zhou, R. W. Doms and M. S. Diamond, J. Virol., 2005, 79, 8698 (dengue virus); K. Whitby, D. Taylor, D. Patel, P. Ahmed and A. S. Tyms, Antiviral Chem. Chemother., 2004, 15, 141 (bovine viral diarrhoea virus); S. P. Ahmed, R. J. Nash, C. G. Bridges, D. L. Taylor, M. S. Kang, E. A. Porter and A. S. Tyms, Biochem. Biophys. Res. Commun., 1995, 208, 267 (HSV-2); C. G. Bridges, T. M. Brennan, D. L. Taylor, M. McPherson and A. S. Tyms, Antiviral Res., 1994, 25, 169 (HIV-1).

87 T. Jank, M. O. Ziegler, G. E. Schulz and K. Aktories, FEBS Lett., 2008, 582, 2277.

88 D. Lyras, J. R. O'Connor, P. M. Howarth, S. P. Sambol, G. Carter, T. Phumoonna, R. Poon, V. Adams, G. Vedantam, S. Johnson, D. N. Gerding and J. I. Rood, Nature, 2009, 458, 1176.

89 For a review of (+)-castanospermine syntheses published prior to 2005, see: M. D. López, J. Cobo and M. Nogueras, Curr. Org. Chem., 2008, 12, 718.

90 L. Cronin and P. V. Murphy, Org. Lett., 2005, 7, 2691.

91 T. Jensen, M. Mikkelsen, A. Lauritsen, T. L. Andresen, C. H. Gotfredsen and R. Madsen, J. Org. Chem., 2009, 74, 8886.

92 B. Schmidt, Eur. J. Org. Chem., 2004, 1865.

93 J. D. White, P. Hrnciar and A. F. T. Yokochi, J. Am. Chem. Soc., 1998, 120, 7359.

94 N. S. Karanjule, S. D. Markad, V. S. Shinde and D. D. Dhavale, J. Org. Chem., 2006, 71, 4667.

95 V. P. Vyavahare, C. Chakraborty, B. Maity, S. Chattopadhyay, V. G. Puranik and D. D. Dhavale, J. Med. Chem., 2007, 50, 5519.

96 N. A. Petasis and I. A. Zavialov, J. Am. Chem. Soc., 1998, 120, 11798 .

97 S. G. Pyne, A. S. Davis, N. J. Gates, J. P. Hartley, K. B. Lindsay, T. Machan and M. Y. Tang, Synlett, 2004, 2670; S. G. Pyne, C. W. G. Au, A. S. Davis, I. R. Morgan, T. Ritthiwigrom and A. Yazici, Pure Appl. Chem., 2008, 80, 751.

98 T. Machan, A. S. Davis, B. Liawruangrath and S. G. Pyne, Tetrahedron, 2008, 64, 2725.

99 A. S. Davis, S. G. Pyne, B. W. Skelton and A. H. White, J. Org. Chem., 2004, 69, 3139.

100 A. J. Murray, P. J. Parsons, E. S. Greenwood and E. M. E. Viseux, Synlett, 2004, 1589.

101 Z. Hong, L. Liu, M. Sugiyama, Y. Fu and C.-H. Wong, J. Am. Chem. Soc., 2009, 131, 8352.

102 J. Ceccon, G. Danoun, A. E. Greene and J. F. Poisson, Org. Biomol. Chem., 2009, 7, 2029.

103 J. Ceccon, A. E. Greene and J. F. Poisson, Org. Lett., 2006, 8, 4739. 104 Z. Zhao, L. Song and P. S. Mariano, Tetrahedron, 2005, 61, 8888. 
105 R. Ling, M. Yoshida and P. S. Mariano, J. Org. Chem., 1996, 61, 4439.

106 L. Svansson, B. D. Johnston, J.-H. Gu, B. Patrick and B. M. Pinto, J. Am. Chem. Soc., 2000, 122, 10769.

107 For reports concerning sulfonium analogues of the glycosidase inhibitor swainsonine, see: I. Izquierdo, M. T. Plaza and F. Aragón, Tetrahedron: Asymmetry, 1996, 7, 2567; A. Siriwardena, H. Strachan, S. El-Daher, G. Way, B. Winchester, J. Glushka, K. Moremen and G. J. Boons, ChemBioChem, 2005, 6, 845 .

108 T. Kajimoto, K. K. C. Liu, R. L. Pederson, Z. Zhong, Y. Ichikawa, J. A. Porco and C. H. Wong, J. Am. Chem. Soc., 1991, 113, 6187.

109 H. Matsuda, T. Morikawa and M. Yoshikawa, Pure Appl. Chem., 2002, 74, 1301.

110 M. Yoshikawa, T. Murakami, H. Shimada, H. Matsuda, J. Yamahara, G. Tanabe and O. Muraoka, Tetrahedron Lett., 1997, 38, 8367.

111 M. Yoshikawa, T. Murakami, K. Yashiro and H. Matsuda, Chem. Pharm. Bull., 1998, 46, 1339.

112 M. Yoshikawa, F. Xu, S. Nakamura, T. Wang, H. Matsuda, G. Tanabe and O. Muraoka, Heterocycles, 2008, 5, 207.

113 M. H. S. Jayawardena, N. M. W. de Alwis, V. Hettigoda and D. J. S. Fernando, J. Ethnopharmacol., 2005, 97, 215; R. Im, H. Mano, S. Nakatani, J. Shimizu and M. Wada, Biosci., Biotechnol., Biochem., 2008, 72, 3075.

114 L. Sim, K. Jayakanthan, S. Mohan, R. Nasi, B. D. Johnston, B. M. Pinto and D. R. Rose, Biochemistry, 2010, 49, 443.

115 Y. Li, T. H.-W. Huang and J. Yamahara, Life Sci., 2008, 82, 1045.

116 M. Yoshikawa, T. Morikawa, H. Matsuda, G. Tanabe and O. Muraoka, Bioorg. Med. Chem., 2002, 10, 1547.

117 H. Yuasa, J. Takada and H. Hashimoto, Tetrahedron Lett., 2000, 41, 6615.

118 A. Ghavami, B. D. Johnston and B. M. Pinto, J. Org. Chem., 2001, 66, 2312.

119 A. Ghavami, K. S. Sadalapure, B. D. Johnston, M. Lobera, B. B. Snider and B. M. Pinto, Synlett, 2003, 1259.

120 For a comprehensive review of these efforts, see: S. Mohan and B. M. Pinto, Carbohydr. Res., 2007, 342, 1551.

121 For a further review of this area, see: H. Yuasa, M. Izumi and H. Hashimoto, Curr. Top. Med. Chem., 2009, 9, 76.

122 A. Ghavami, B. D. Johnston, M. T. Jensen, B. Svensson and B. M. Pinto, J. Am. Chem. Soc., 2001, 123, 6268.

123 O. Muroaka, S. Ying, K. Yoshikai, Y. Matsuura, E. Yamada, T. Minematsu, G. Tanabe, H. Matsuda and M. Yoshikawa, Chem. Pharm. Bull., 2001, 49, 1503.

124 For examples of bioactive chain-extended, salicinol N-congeners, see:H. Liu, L. Sim, D. R. Rose and B. M. Pinto, J. Org. Chem., 2006, 71, 3007.

125 B. D. Johnston, A. Ghavami, M. T. Jensen, B. Svensson and B. M. Pinto, J. Am. Chem. Soc., 2002, 124, 8245; H. Liu and B. M. Pinto, J. Org. Chem., 2005, 70, 753.

126 E. J. Rossi, L. Sim, D. A. Kuntz, D. Hahn, B. D. Johnston, A. Ghavami, M. G. Szczepina, N. S. Kumar, E. E. Sterchi, B. L. Nichols, B. M. Pinto and D. R. Rose, FEBS J., 2006, 273, 2673.

127 A. Ghavami, B. D. Johnston, M. D. Maddess, S. M. Chinapoo, M. T. Jensen, B. Svensson and B. M. Pinto, Can. J. Chem., 2002, 80, 937.

128 E. Gallienne, M. Benazza, G. Demailly, J. Bolte and M. Lemaire, Tetrahedron, 2005, 61, 4557.

129 E. Gallienne, T. Gefflaut, J. Bolte and M. Lemaire, J. Org. Chem., 2006, 71, 894

130 M. G. Szczepina, B. D. Johnston, Y. Yuan, B. Svensson and B. M. Pinto, J. Am. Chem. Soc., 2004, 126, 12458

131 B. D. Johnston, H. H. Jensen and B. M. Pinto, J. Org. Chem., 2006, 71, 1111.

132 H. Liu, R. Nasi, K. Jayakanthan, L. Sim, H. Heipel, D. R. Rose and B. M. Pinto, J. Org. Chem., 2007, 72, 6562.

133 S. Mohan, L. Sim, D. R. Rose and B. M. Pinto, Carbohydr. Res., 2007, 342, 901 .

134 For an earlier example of bioactive $S$-methyl sulfonium inhibitors, see: H. Yuasa, J. Takada and H. Hashimoto, Bioorg. Med. Chem. Lett., 2001, 11, 1137

135 G. Tanabe, K. Yoshikai, T. Hatanaka, M. Yamamoto, Y. Shao, T. Minematsu, O. Muraoka, T. Wang, H. Matsuda and M. Yoshikawa, Bioorg. Med. Chem., 2007, 15, 3926.
136 R. Nasi, B. O. Patrick, L. Sim, D. R. Rose and B. M. Pinto, J. Org. Chem., 2008, 73, 6172 .

137 J. K. N. Jones and R. A. Wall, Nature, 1961, 189, 746 and references cited therein

138 A. T. Ness, R. M. Hann and C. S. Hudson, J. Am. Chem. Soc., 1948, 70, 765 .

139 S. Ozaki, O. Hiromi and S. Kitamura, J. Nat. Prod., 2008, 71, 981.

140 O. Muraoka, W. Xie, G. Tanabe, M. F. A. Amer, T. Minematsu and M. Yoshikawa, Tetrahedron Lett., 2008, 49, 7315.

141 M. Yoshikawa, F. Xu, S. Nakamura, T. Wang, H. Matsuda, G. Tanabe and O. Muraoka, Heterocycles, 2008, 75, 1397.

142 H. Oe and S. Ozaki, Biosci., Biotechnol., Biochem., 2008, 72, 1962.

143 G. Tanabe, M. Sakano, T. Minematsu, H. Matusda, M. Yoshikawa and O. Muraoka, Tetrahedron, 2008, 64, 10080.

144 M. Asada, Y. Kawahara and S. Kitamura, US Pat. 0037 870, 2007.

145 M. Yoshikawa, F. Xu, S. Nakamura, T. Wang, H. Matsuda, G. Tanabe and O. Muraoka, Heterocycles, 2008, 75, 1397.

146 Y. Gao and K. B. Sharpless, J. Am. Chem. Soc., 1988, 110, 7538.

147 Y. Minami, C. Kuriyama, K. Ikeda, A. Kato, K. Takebayashi, I. Adachi, G. W. J. Fleet, A. Kettawan, T. Okamoto and N. Asano, Bioorg. Med. Chem., 2008, 16, 2734.

148 G. Tanabe, W. Xie, A. Ogawa, C. Cao, T. Minematsu, M. Yoshikawa and O. Muraoka, Bioorg. Med. Chem. Lett., 2009, 19, 2195.

149 G. E. McCasland, S. Furta and L. J. Durham, J. Org. Chem., 1966, 31, 1516; G. E. McCasland, S. Furta and L. J. Durham, J. Org. Chem., 1968, 33, 2841; G. E. McCasland, S. Furta and L. J. Durham, J. Org. Chem., 1968, 33, 2835.

150 T. W. Miller, B. H. Arison and G. Albers-Schonberg, Biotechnol. Bioeng., 1973, 15, 1075.

151 For reviews of carbasugars and aminocyclitols, see: T. Mahmud, Nat. Prod. Rep., 2003, 20, 137; X. Chen, Y. Fan, Y. Zheng and Y. Shen, Chem. Rev., 2003, 103, 1955.

152 For recent reviews, see: J. Plument, A. M. Gómez and J. C. López, Mini-Rev. Org. Chem., 2007, 4, 201; O. Arjona, A. M. Gómez, J. López and J. Plumet, Chem. Rev., 2007, 107, 1919.

153 Y. Kameda and S. Horii, Chem. Commun., 1972, 746.

154 Y. K. Chang, B. Y. Lee, D. J. Kim, G. S. Lee, H. B. Jeon and K. S. Kim, J. Org. Chem., 2005, 70, 3299.

155 I. Cumpstey, Tetrahedron Lett., 2005, 46, 6257.

156 H. Fukase and S. Horii, J. Org. Chem., 2005, 70, 3299.

157 Y.-K. Chang, H.-J. Lo and T.-H. Yan, Org. Lett., 2009, 11, 4278.

158 P. R. Krishna and P. S. Reddy, Synlett, 2009, 209.

159 S. Horii, H. Fukase, T. Matsuo, Y. Kameda, N. Asano and K. Matsui, J. Med. Chem., 1986, 29, 1038.

160 X. Chen, Y. Zheng and Y. Shen, Curr. Med. Chem., 2006, 13, 109

161 T. K. Shing and H. M. Cheng, Org. Lett., 2008, 10, 4137.

162 T. K. Shing, H. M. Cheng, W. F. Wong, C. S. Kwong, J. Li, C. B. Lau, P. S. Leung and C. H. Cheng, Org. Lett., 2008, 10, 3145.

163 For selected examples of marine $\alpha$-glucosidase inhibitors, see: S. J. Heo, J. Y. Hwang, J. I. Choi, J. S. Han, H. J. Kim and Y. J. Jeon, Eur. J. Pharmacol., 2009, 615, 252(diphlorethohydroxycarmalol)N. Ingavat, J. Dobereiner, S. Wiyakrutta, C. Mahidol, S. Ruchirawat and P. Kittakoop, J. Nat. Prod., 2009, 72, 2049 (aspergillusol A); J. P. Saludes, S. C. Lievens and T. F. Molinski, J. Nat. Prod., 2007, 70, 436 (1,4-dideoxy-1,4-imino-D-arabinitol); Y. Nakao, T. Uehara, S. Matsunaga, N. Fusetani and R. W. Van Soest, J. Nat. Prod., 2002, 65, 922 (callyspongynic acid).

164 For an overview of these efforts, see: Y. Nakao and N. Fusetani, J. Nat. Prod., 2007, 70, 689.

165 K. Takada, T. Uehara, Y. Nakao, S. Matsunaga, R. W. M. van Soest and N. Fusetani, J. Am. Chem. Soc., 2004, 126, 187.

166 Y. Nakao, T. Maki, S. Matsunaga, R. W. M. van Soest and N. Fusetani, Tetrahedron, 2000, 56, 8977.

167 Y. Nakao, T. Maki, S. Matsunaga, R. W. M. Van Soest and N. Fusetani, J. Nat. Prod., 2004, 67, 1346.

168 K. Takada, T. Uehara, Y. Nakao, S. Matsunaga, R. W. M. van Soest and N. Fusetani, J. Am. Chem. Soc., 2004, 126, 187.

169 A. R. Carroll, M. S. Buchanan, A. Edser, E. Hyde, M. Simpson and R. J. Quinn, J. Nat. Prod., 2004, 67, 1291; A. J. Roccatagliata, M. S. Maier, A. M. Seldes, S. Zea and C. Duque, J. Nat. Prod., 1997, 60, 285; N. K. Gulavita, S. A. Pomponi, A. E. Wright, M. Garay and M. A. Sills, J. Nat. Prod., 1995, 58, 954; Y. Nakao, 
S. Matsunaga and N. Fusetani, Tetrahedron, 1993, 49, 11183; S. Kanazawa, N. Fusetani and S. Matsunaga, Tetrahedron, 1992, 48, 5467.

170 D. K. Mohapatra, D. Bhattasali, M. K. Gurjar, M. I. Khan and K. S. Shashidhara, Eur. J. Org. Chem., 2008, 6213.

171 P. Kuntiyong, S. Akkarasamiyo and G. Eksinitkun, Chem. Lett., 2006, 35, 1008.
172 M. K. Gurjar, C. Pramanik, D. Bhattasali, C. V. Ramana and D. K. Mohapatra, J. Org. Chem., 2007, 72, 6591.

173 G. Liu and D. Romo, Org. Lett., 2009, 11, 1143.

174 E. J. Corey and J. O. Link, J. Am. Chem. Soc., 1992, 114, 1906.

175 R. Tennyson, G. C. Cortez, H. J. Galicia, C. R. Kreiman, C. M. Thompson and D. Romo, Org. Lett., 2002, 4, 533 .

176 E. G. Bowen and D. J. Wardrop, J. Am. Chem. Soc., 2009, 131, 6062. 